\title{
Review \\ Fermentation of Cereals and Legumes: Impact on Nutritional Constituents and Nutrient Bioavailability
}

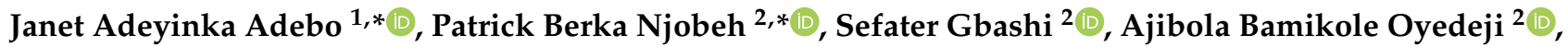 \\ Opeoluwa Mayowa Ogundele ${ }^{2}$, Samson Adeoye Oyeyinka ${ }^{2}$ and Oluwafemi Ayodeji Adebo ${ }^{2, *} \mathbb{C}$ \\ 1 Food Evolution Research Laboratory, Bunting Campus, School of Hospitality and Tourism, College of \\ Business and Economics, University of Johannesburg, P.O. Box 17011, Johannesburg 2028, South Africa \\ 2 Department of Biotechnology and Food Technology, Doornfontein Campus, Faculty of Science, \\ University of Johannesburg, P.O. Box 17011, Johannesburg 2028, South Africa; \\ sefatergbashi@gmail.com (S.G.); jibanky2@gmail.com (A.B.O.); blaskino1103@gmail.com (O.M.O.); \\ sartf2001@yahoo.com (S.A.O.) \\ * Correspondence: janetaadex@gmail.com (J.A.A.); pnjobeh@uj.ac.za (P.B.N.); oadebo@uj.ac.za (O.A.A.)
}

check for

updates

Citation: Adebo, J.A.; Njobeh, P.B.; Gbashi, S.; Oyedeji, A.B.; Ogundele, O.M.; Oyeyinka, S.A.; Adebo, O.A. Fermentation of Cereals and Legumes: Impact on Nutritional Constituents and Nutrient Bioavailability. Fermentation 2022, 8 , 63. https://doi.org/10.3390/ fermentation 8020063

Academic Editor: Viola Galli

Received: 16 December 2021

Accepted: 27 January 2022

Published: 30 January 2022

Publisher's Note: MDPI stays neutral with regard to jurisdictional claims in published maps and institutional affiliations.

Copyright: (C) 2022 by the authors. Licensee MDPI, Basel, Switzerland. This article is an open access article distributed under the terms and conditions of the Creative Commons Attribution (CC BY) license (https:// creativecommons.org/licenses/by/ $4.0 /)$.

\begin{abstract}
Fermented food products, especially those derived from cereals and legumes are important contributors to diet diversity globally. These food items are vital to food security and significantly contribute to nutrition. Fermentation is a process that desirably modifies food constituents by increasing the palatability, organoleptic properties, bioavailability and alters nutritional constituents. This review focuses on deciphering possible mechanisms involved in the modification of nutritional constituents as well as nutrient bioavailability during the fermentation of cereals and legumes, especially those commonly consumed in developing countries. Although modifications in these constituents are dependent on inherent and available nutrients in the starting raw material, it was generally observed that fermentation increased these nutritive qualities (protein, amino acids, vitamins, fats, fatty acids, etc.) in cereals and legumes, while in a few instances, a reduction in these constituents was noted. A general reduction trend in antinutritional factors was also observed with a corresponding increase in the nutrient bioavailability and bioaccessibility. Notable mechanisms of modification include transamination or the synthesis of new compounds during the fermentation process, use of nutrients as energy sources, as well as the metabolic activity of microorganisms leading to a degradation or increase in the level of some constituents. A number of fermented products are yet to be studied and fully understood. Further research into these food products using both conventional and modern techniques are still required to provide insights into these important food groups, as well as for an overall improved food quality, enhanced nutrition and health, as well as other associated socioeconomic benefits.
\end{abstract}

Keywords: fermented foods; cereal and legume-based product; antinutrients; nutrient bioavailability; socioeconomic benefits

\section{Introduction}

Fermented food products are notable all around the world and are sometimes categorized as "functional foods" due to their purported health benefits. These food products have been in existence since the arrival of the human civilization and are likely to be with us far into the future. Fermentation is, thus, an age-long food processing technique used to transform food products [1,2], with different food crops (cereals, legumes, as well as fruits and vegetables) used as starting raw materials. Cereals and legumes are notable and major staple crops around the globe and are frequently fermented to obtain a number of food products [3-5]. The fermentation of cereals and legumes, as with other food crops, can be classified into three categories, viz., natural (also referred to as spontaneous), back slopping and controlled fermentation. Natural or spontaneous fermentation occurs through the sequential and competitive action of a plethora of microorganisms, with the best-adapted 
strain(s) having a better growth rate, eventually dominating the microbiota $[2,6]$. Back slopping fermentation is similar to natural or spontaneous fermentation and a common traditional practice in low-income households and small-scale commercial industries. This process involves the introduction of a small portion of an earlier successful fermentation batch into a new process, to serve as a source of "starter cultures" and guarantees an effective transfer of microorganisms responsible for fermentation $[1,2,6]$. Controlled fermentation, on the other hand, involves the use of specific strains (starter cultures). Such strains have been isolated earlier and identified and their subsequent use in a controlled fermentation process leads to shorter lag phases, among other benefits $[7,8]$. Natural fermentation is, however, non-predictable and less effective, although it is the most common form of fermentation in developing countries, especially in Africa and Asia [1,2]. Because of these limitations, starter cultures such as LAB, yeasts, fungi, Bacillus species and other microorganisms have been isolated from fermented products and adopted to make the fermentation process more reliable, controlled and reproducible $[1,9,10]$.

Additionally, fermentation could also be classified as either a solid-state fermentation (SSF) or submerged/liquid (SmF) fermentation. The SSF process involves the growth of microorganisms on moist substrates in the absence of free-flowing water, while SmF occurs in the presence of free-flowing liquid medium/water (i.e., SmF has more fluids compared to SSF) [11,12]. Irrespective of these classifications, the primary purpose of food fermentation is to preserve perishable produce; however, recently, with the advent of numerous technologies, different types of fermented foods are being manufactured to meet consumer needs [2,13]. This food processing technique is also well-known to improve the sensory properties of food through imparting unique flavours, textures and aromas. It is also used to improve the bioavailability and bioaccessibility of nutrients, reduce antinutritional factors (such as lectins, phytic acid, proteinase inhibitors, oxalic and tannins acids) and pathogenic microorganisms, preserve food products as well as to enhance the economic value [14,15].

Most well-known fermented foods in Africa and Asia are produced from cereals and legumes to create a variety of diets for households. The fermentation of cereals and legumes into subsequent products involves the interaction of plant tissues with available fermenting microorganisms. These fermented foods mostly contain a complex mixture of proteins, carbohydrates, fats, etc., undergoing a simultaneous modification or in some sequence under the action of a variety of microorganisms and enzymes [16]. Subsequent changes of these nutritional constituents would, thus, be dependent on available nutrients and precursors in the raw material, metabolic capabilities of the raw material and fermentation microorganisms, fermentation conditions as well as interactions among all these suggested elements $[1,2,17]$. Furthermore, it depends on the particle size distribution of raw materials, water availability, diffusion rates of nutrients and oxygen during fermentation, available microorganisms during fermentation as well as the form of fermentation process (spontaneous/natural, controlled (using starter cultures) or back-slopping) [12,18]. This review, thus, attempts to systematize the knowledge concerning the fermentation process of various nutrients in fermented cereal and legume-based products.

\section{Effect of Fermentation on the Nutritional Constituents and Bioavailability of Cereals and Legumes}

A number of available studies in the literature have identified different fermented cereal and legume-based products, including condiments, gruels, soups, beverages and porridges (Tables 1 and 2). These products were obtained through natural, back slopping and controlled fermentation. From the literature reviewed, most of the nutritional components investigated and reported included a proximate composition (carbohydrates, fat, protein, ash and crude fibre), energy, starch and fibre fractions, amino acids, minerals and fatty acids. While other constituents not usually investigated were vitamins and fatty acids. Additionally, associated with these nutritional constituents are antinutritional factors, including trypsin inhibitors, tannins, etc., which limit the nutrient bioavailability. These 
constituents, conditions under which the fermentation process was performed, the fermented products as well as the percentage differences after fermentation were summarized in Tables 3 and 4, with reported mechanisms of modification described (Figures 1 and 2) in the ensuing sections.

\subsection{Protein and Amino Acids}

According to Kumitch [11] and Adhikari et al. [127], fermentation is one of the best food processing techniques that can improve protein levels of cereals and legumes. However, different study durations, experimental designs and raw materials do not entirely agree to this assertion (Tables 3 and 4), as most studies reported increases, but some others reported decrease in protein levels.

During the fermentation of pearl millet to fermented pearl millet flour, Adebiyi et al. [128] reported a $6 \%$ and $78 \%$ increase in protein and AAs, respectively, with the authors attributing this to the increase activities of hydrolytic enzymes, the degradation of complex proteins to AAs through proteolysis as well as the production of additional AAs during fermentation. Similarly, a $4 \%$ increase in the protein content of fermented instant fura (from pearl millet) was observed and reportedly caused by the production of some AAs more than the requirement during protein synthesis, and these tended to accumulate into an AA pool [129]. The authors also suggested that the degradation of storage protein and synthesis of new protein could have caused this increase. An increase in protein levels and AA compositions was reported in oats (Avena sativa) fermented with the oyster mushroom Pleurotus ostreatus CS155 strain for $336 \mathrm{~h}$ (two weeks) at room temperature [130]. The increase in AA synthesis was as a result of the fermentation with Pleurotus ostreatus [130]. Pearl millet fermented at $24 \mathrm{~h}$ also had an increased protein content due to the loss of carbohydrates, while the same study reported a decrease in arginine, lysine and glycine [131]. In total, $4.2-16.3 \%$ and $13 \%$ increased protein levels in fermented sorghum flour [132] and fermented rice flour [133], respectively, were attributed to the accumulation of microbial cells of the fermenting organisms which both studies suggested could have contributed to the increase in protein. Although Suarti et al. [134] reported a $3-20 \%$ increase in proteins of fermented rice, ascribing this to the metabolic capacity of the fungi during the fermentation process, a $0.3 \%$ decrease was equally reported in some rice varieties, with this decrease attributed to the degradation of protein molecules into AAs by Rhizopus oligosporus at the end of the $72 \mathrm{~h}$ fermentation, to support their growth. Other authors reporting an increase in proteins during the fermentation of cereals have ascribed this to activities of proteolytic enzymes produced by the fermenting organisms and protein synthesis during fermentation $[135,136]$. Though seldom so, decreases in protein levels have also been reported in fermented rice (8-19\%) [137], fermented maize (9\%) [138], fermented sorghum (13\%) [139] and a study on ogi from two maize varieties (15-24\%), attributing this to the leaching of protein into fermenting water and/or the action of degrading enzymes (e.g., proteolytic enzymes), which could have broken down the protein to its lower fractions [140]. While these studies did not investigate AAs, it could possibly be speculated that such degradations might have led to increased AA levels. 
Table 1. Some cereal fermented products and associated microorganisms responsible for fermentation.

\begin{tabular}{|c|c|c|c|c|c|}
\hline Product & Raw Materials & Product Form & Microorganisms Involved & Country/Region & Reference \\
\hline \multicolumn{6}{|l|}{ Cereal-Based } \\
\hline Abreh & Sorghum & Beverage & Lactiplantibacillus plantarum & Sudan & Odunfa and Oyewole [19] \\
\hline Aceda & Sorghum & Thick porridge & Unknown & Sudan & Eggum et al. [20] \\
\hline Aliha & Maize/sorghum & Beverage & Lactic acid bacteria (LAB) & Benin, Ghana, Togo & Odunfa and Oyewole [19] \\
\hline Amazake & Rice & Beverage & Aspergillus spp. & Japan & Marsh et al. [21] \\
\hline Ang kak & Rice & Colorant & Monascus purpureus & $\begin{array}{l}\text { China, Philippines, Taiwan, } \\
\text { Thailand }\end{array}$ & Steinkraus [22] \\
\hline Apem & Rice & Bread & $\begin{array}{l}\text { Leuconostoc mesenteroides and Saccharomyces spp. } \\
\text { Enterococcus asini, Enterococcus casseliflavus, } \\
\text { Enterococcus faecium, Enterococcus hirae, Enterococcus } \\
\text { mundtii, Lactococcus lactis, Lactococcus piscium, } \\
\text { Agrilactobacillus composti, Lacticaseibacillus casei, } \\
\text { Lacticaseibacillus paracasei, Lacticaseibacillus rhamnosus, } \\
\text { Lactiplantibacillus fabifermentans, Lactiplantibacillus } \\
\text { paraplantarum, Lactiplantibacillus pentosus, }\end{array}$ & Bali, Indonesia & Wang and Hesseltine [23] \\
\hline Atole agrio & Maize & Beverage & $\begin{array}{l}\text { Lactiplantibacillus plantarum, Latilactobacillus curvatus, } \\
\text { Lactobacillus dixtrinicus, Levilactobacillus brevis, } \\
\text { Ligilactobacillus araffinosus, Liquorilactobacillus mali, } \\
\text { Loigolactobacillus coryniformis, Leuconostoc garlicum, } \\
\text { Leuconostoc mesenteroides, Leuconostoc } \\
\text { pseudomesenteroides, Pediococcus pentosaceus, } \\
\text { Pediococcus stilesii, Streptococcus equines, Weissella } \\
\text { cibaria, Weissella confusa, Weissella hellenica, Weissella } \\
\text { oryzae and Weissella paramesenteroides }\end{array}$ & Mexico & $\begin{array}{l}\text { Pérez-Cataluña et al. [24]; } \\
\text { Väkeväinen et al. [25] }\end{array}$ \\
\hline Bagni & Millet & Alcoholic beverage & $\mathrm{LAB}$ and yeasts & Russia & Tamang et al. [4] \\
\hline Banku & Maize and cassava & Dough as staple & Lactobacillus spp., yeasts and moulds & Ghana & $\begin{array}{l}\text { Blandino et al. [3]; } \\
\text { Campbell-Platt [26] }\end{array}$ \\
\hline Ben-saalga & Pearl millet & Gruel & $\begin{array}{l}\text { Lactobacillus spp., Leuconostoc spp., Pediococcus spp., } \\
\text { Weissela spp. and yeasts }\end{array}$ & Burkina Faso, Ghana & Tou et al. [27] \\
\hline Bouza & Wheat & Alcoholic beverage & $\mathrm{LAB}$ & Egypt & Steinkraus [22] \\
\hline Burukutu & Sorghum & Alcoholic beverage & $\begin{array}{l}\text { Acetobacter spp., Candida spp., Enterobacter spp., } \\
\text { Lactobacillus spp., Leuconostoc mesenteroides, } \\
\text { Saccharomyces cerevisiae and Saccharomyces chavelieri }\end{array}$ & Benin, Ghana, Nigeria & $\begin{array}{l}\text { Kolawole et al. [28]; Eze et al. } \\
\text { [29]; Alo et al. [30] }\end{array}$ \\
\hline Busa & $\begin{array}{l}\text { Millet, maize or } \\
\text { sorghum }\end{array}$ & Beverage & $\begin{array}{l}\text { Lactobacillus spp., Leuconostoc mesenteroides, } \\
\text { Pediococcus damnosus and Saccharomyces spp. }\end{array}$ & East Africa, Kenya & Odunfa and Oyewole [19] \\
\hline
\end{tabular}


Table 1. Cont.

\begin{tabular}{|c|c|c|c|c|c|}
\hline Product & Raw Materials & Product Form & Microorganisms Involved & Country/Region & Reference \\
\hline \multicolumn{6}{|l|}{ Cereal-Based } \\
\hline Bushera & Sorghum & Beverage & $\begin{array}{l}\text { Enterococcus spp., Lacticaseibacillus paracasei, } \\
\text { Lactobacillus delbrueckii, Lactiplantibacillus plantarum, } \\
\text { Levilactobacillus brevis, and Streptococcus thermophilus }\end{array}$ & Uganda & Marsh et al. [21]; Mwale [31] \\
\hline Cheka & Sorghum/maize & Beverage & Unknown & Ethiopia & Worku et al. [32] \\
\hline Chibuku & Sorghum & Alcoholic beverage & Lactobacillus spp. & Botswana, Zimbabwe & $\begin{array}{l}\text { Gadaga et al. [33]; Togo } \\
\text { et al. [34] }\end{array}$ \\
\hline Chicha & Maize & Beverage & Acetobacter and LAB & Peru & Bassi et al. [35] \\
\hline Darassum & Millet & Beverage & $\begin{array}{l}\text { Unknown } \\
\text { Lacticaseibacillus casei, Lactobacillus gasseri, }\end{array}$ & Mongolia & Blandino et al. [3] \\
\hline Dégué & Millet & Condiment & $\begin{array}{l}\text { Levilactobacillus brevis, Limosilactobacillus fermentum } \\
\text { and Enterococcus spp. }\end{array}$ & Burkina Faso & Abriouel et al. [36] \\
\hline Doklu & Maize & Dough & $\begin{array}{l}\text { Enterococcus spp., Lactiplantibacillus plantarum, } \\
\text { Limosilactobacillus fermentum, Pediococcus acidilactici, } \\
\text { Pediococcus pentosaceus, Streptococcus spp., Weissella } \\
\text { cibaria }\end{array}$ & Côte d'Ivoire & Assohoun-Djeni et al. [37] \\
\hline Dolo & Sorghum & Alcoholic beverage & $\begin{array}{l}\text { Lactobacillus delbrueckii, Limosilactobacillus fermentum, } \\
\text { Lactococcus lactis, Pediococcus acidilactici and } \\
\text { Saccharomyces cerevisae }\end{array}$ & Burkina Faso, Togo & $\begin{array}{l}\text { Van der Aa Kühle et al. [38]; } \\
\text { Sawadogo-Lingani et al. [39] }\end{array}$ \\
\hline Doro & Millet/sorghum & Alcoholic beverage & Bacteria and yeast & Zimbabwe & Blandino et al. [3] \\
\hline Enturire & Sorghum & Alcoholic beverage & $\begin{array}{l}\text { Lactiplantibacillus plantarum, Saccharomyces cerevisae, } \\
\text { Weissela confusa }\end{array}$ & Uganda & Mukisa et al. [40] \\
\hline Gowe & Sorghum & Porridge & $\begin{array}{l}\text { Candida krusei, Candida tropicalis, Kluyveromyces } \\
\text { marxianus, Limosilactobacillus fermentum and } \\
\text { Limosilactobacillus mucosae }\end{array}$ & Benin & $\begin{array}{l}\text { Greppi et al. [41]; } \\
\text { Adinsi et al. [42] }\end{array}$ \\
\hline Hussuwa & Sorghum & Cooked dough & $\begin{array}{l}\text { Acetobacter xylinum, Gluconobacter oxydans, } \\
\text { Lactobacillus saccharolyticum, Limosilactobacillus } \\
\text { fermentum, Pediococcus acidilactici, Pediococcus } \\
\text { pentosaceus, Saccharomyces cerevisiae and yeasts }\end{array}$ & Sudan & Mwale [31]; Yousif et al. [43] \\
\hline Injera & Tef flour/wheat & Flatbread & $\begin{array}{l}\text { Candida glabrata, Lactiplantibacillus plantarum, } \\
\text { Leuconostoc mesenteroides, Limosilactobacillus pontis, } \\
\text { Pediococcus cerevisiae and Saccharomyces cerevisiae }\end{array}$ & Ethiopia & Olasupo et al. [44] \\
\hline Jalebies & Wheat flour & Snack & Saccharomyces bayanus & India, Nepal, Pakistan & Blandino et al. [3] \\
\hline
\end{tabular}


Table 1. Cont.

\begin{tabular}{|c|c|c|c|c|c|}
\hline Product & Raw Materials & Product Form & Microorganisms Involved & Country/Region & Reference \\
\hline \multicolumn{6}{|l|}{ Cereal-Based } \\
\hline Jhan chang & Barley flour & Snack & Unknown & India & Kanwar et al. [45] \\
\hline Kenkey & Maize & Dough & $\begin{array}{l}\text { Candida kefir, Candida krusei, Candida mycoderma, } \\
\text { Candida tropicalis, Limosilactobacillus fermentum, } \\
\text { Limosilactobacillus reuteri and Saccharomyces cerevisiae }\end{array}$ & Ghana & Odunfa and Oyewole [19] \\
\hline Keribo & Barley & Beverage & LAB & Ethiopia & Tafere [46] \\
\hline Kishk & Wheat, oat & Soup & $\begin{array}{l}\text { Bacillus subtilis, Lacticaseibacillus casei, Lacticaseibacillus } \\
\text { rhamnosus, Lactiplantibacillus plantarum, } \\
\text { Latilactobacillus sakei, Levilactobacillus brevis and yeasts }\end{array}$ & Arabic countries, Egypt, Syria & Kohajdová [47] \\
\hline Kisra & Sorghum & $\begin{array}{l}\text { Flat bread, pancake } \\
\text { and sourdough }\end{array}$ & $\begin{array}{l}\text { Candida intermedia, Candida krusei, Debrayomyces } \\
\text { hansenii, Enterococcus faecium, Lactobacillus amylovorus, } \\
\text { Lactobacillus confusus, Levilactobacillus brevis, } \\
\text { Limosilactobacillus fermentum and Pichia kudriavzevii }\end{array}$ & Sudan & $\begin{array}{l}\text { Mohammed et al. [48]; } \\
\text { Hamad et al. [49] }\end{array}$ \\
\hline Khanom-jeen & Rice & Noodle & Lactobacillus spp., Streptococcus spp. & Thailand & Blandino et al. [3] \\
\hline Koko & Maize & Porridge & $\begin{array}{l}\text { Lactiplantibacillus plantarum, Levilactobacillus brevis and } \\
\text { Saccharomyces cerevisiae }\end{array}$ & Ghana & Von Mollendor et al. [50] \\
\hline Kunu-zaki & Maize/sorghum/millet & & $\begin{array}{l}\text { Aerobacter spp., Aspergillus spp., Candida mycoderma, } \\
\text { Cephalosporium spp., Corynebacterium spp., Fusarium } \\
\text { spp., Lacticaseibacillus pantheris, Lactiplantibacillus } \\
\text { plantarum, Paucilactobacillus vaccinostercus, Penicillium } \\
\text { spp., Rhodotorula spp. and Saccharomyces cerevisiae }\end{array}$ & Nigeria & Franz and Holzapfel [51] \\
\hline Kutukutu & Maize & Dough & $\begin{array}{l}\text { Lactobacillus spp., Lactococcus spp., Streptococcus spp. } \\
\text { and Leuconostoc spp. }\end{array}$ & Cameroon & Tchikoua et al. [52] \\
\hline Kvass & Rye & Beverage & $\begin{array}{l}\text { Lacticaseibacillus casei, Lactobacillus mesenteroides and } \\
\text { Saccharomyces cerevisiae }\end{array}$ & Central Europe & $\begin{array}{l}\text { Blandino et al. [3]; } \\
\text { Kohajdová [47] }\end{array}$ \\
\hline Mahewu & Maize & Beverage & $\begin{array}{l}\text { Lactobacillus delbrueckii, Lactococcus lactis, Leuconostoc } \\
\text { spp. and Streptococcus lactis }\end{array}$ & $\begin{array}{l}\text { Arabian gulf countries, South } \\
\text { Africa }\end{array}$ & $\begin{array}{l}\text { Prado et al. [53]; } \\
\text { Franz et al. [54] }\end{array}$ \\
\hline Mawè & Maize & Dough & LAB and yeast & Benin, Nigeria, Togo & $\begin{array}{l}\text { Greppi et al. [41]; } \\
\text { Hounhouigan et al. [55]; } \\
\text { Agati et al. [56] }\end{array}$ \\
\hline Mbege & $\begin{array}{l}\text { Maize, millet or } \\
\text { sorghum }\end{array}$ & Beverage & $\begin{array}{l}\text { Lactiplantibacillus plantarum, Leuconostoc mesenteroides, } \\
\text { Saccharomyces cerevisiae and Schizosaccharomyces } \\
\text { pombe }\end{array}$ & Tanzania & Odunfa and Oyewole [19] \\
\hline Merissa & Sorghum and millet & Alcoholic beverage & Saccharomyces spp. & Sudan & Blandino et al. [3] \\
\hline
\end{tabular}


Table 1. Cont.

\begin{tabular}{|c|c|c|c|c|c|}
\hline Product & Raw Materials & Product Form & Microorganisms Involved & Country/Region & Reference \\
\hline \multicolumn{6}{|l|}{ Cereal-Based } \\
\hline Munkoyo & Maize & Beverage & Lactobacillus spp. and Weisella spp. & Southern Africa & Schoustra et al. [57] \\
\hline Mutwiwa & Maize & Porridge & Pediococcus pentosaceus & Zimbabwe & Gadaga et al. [33] \\
\hline Ogi & $\begin{array}{l}\text { Maize, millet or } \\
\text { sorghum }\end{array}$ & Gruel & $\begin{array}{l}\text { Acetobacter spp.; Candida krusei; Corynebacterium spp.; } \\
\text { Lactiplantibacillus plantarum, Lactobacillus acidophilus, } \\
\text { Lactobacillus cellobiosus, Lactobacillus confusus, } \\
\text { Ligilactobacillus agilis, Ligilactobacillus murinus, } \\
\text { Limosilactobacillus fermentum and Saccharomyces } \\
\text { cerevisiae }\end{array}$ & West Africa & $\begin{array}{l}\text { Kuye and Sanni [58]; Omemu } \\
\text { and Bankole [59] }\end{array}$ \\
\hline Otika & Sorghum & Alcoholic beverage & $\begin{array}{l}\text { Bacillus cereus, Bacillus subtilis, Candida krusei, Candida } \\
\text { tropicalis, Enterobacter clocae, Lactiplantibacillus } \\
\text { plantarum, Levilactobacillus brevis, Limosilactobacillus } \\
\text { fermentum, Leuconostoc mesenteroides and } \\
\text { Saccharomyces cerevisae }\end{array}$ & Nigeria & Oriola et al. [60] \\
\hline Pito & Sorghum & Alcoholic beverage & $\begin{array}{l}\text { Bacillus subtillis, Candida spp., Geotrichum candidum } \\
\text { and Lactobacillus spp. }\end{array}$ & Ghana, Nigeria & $\begin{array}{l}\text { Blandino et al. [3]; } \\
\text { Sawadogo-Lingani et al. [39] }\end{array}$ \\
\hline Poto poto & Maize & Dough & $\begin{array}{l}\text { Enterococcus spp., Escherichia coli, Lactiplantibacillus } \\
\text { plantarum, Lactobacillus acidophilus, Lactobacillus casei, } \\
\text { Lactobacillus delbrueckii, Lactobacillus gasseri, and } \\
\text { Limosilactobacillus reuteri }\end{array}$ & Congo & Abriouel et al. [36] \\
\hline Pozol & Maize & Beverage & $\begin{array}{l}\text { Bifidobacterium spp., Enterococcus spp., Lactococcus } \\
\text { lactis, Lacticaseibacillus casei, Lactiplantibacillus } \\
\text { plantarum, Lactobacillus alimentarium, Lactobacillus } \\
\text { delbruekii, and Streptococcus suis }\end{array}$ & Mexico & Marsh et al. [21] \\
\hline Saké & Rice & Alcoholic beverage & $\begin{array}{l}\text { Aspergillus oryzae, Latilactobacillus sakei, Leuconostoc } \\
\text { mesenteroides, Saccharomyces cerevisiae and } \\
\text { Saccharomyces sake }\end{array}$ & Japan & $\begin{array}{l}\text { Blandino et al. [3]; Kotaka } \\
\text { et al. [61] }\end{array}$ \\
\hline Shaosinghiu & Rice & Beverage & Saccharomyces cerevisiae & China & Blandino et al. [3] \\
\hline Takju & Rice/wheat & Beverage & $\begin{array}{l}\text { LAB and Saccharomyces cerevisiae } \\
\text { Aspergillus spp., Lactiplantibacillus plantarum, }\end{array}$ & Korea & Blandino et al. [3] \\
\hline Tapuy & Rice & Alcoholic beverage & $\begin{array}{l}\text { Leuconostoc spp., Mucor spp., Rhizopus spp. and } \\
\text { Saccharomyces spp. }\end{array}$ & Philippines & Ray et al. [62] \\
\hline Tchapalo & Sorghum & Alcoholic beverage & $\begin{array}{l}\text { Lactiplantibacillus plantarum, Lactobacillus cellobiosus, } \\
\text { Lactobacillus coprophilus, Lentilactobacillus hilgardii, } \\
\text { Levilactobacillus brevis and Limosilactobacillus fermentum }\end{array}$ & Côte d'Ivoire & $\begin{array}{l}\text { Djè et al. [63]; N'guessan et al. } \\
\text { [64] }\end{array}$ \\
\hline
\end{tabular}


Table 1. Cont.

\begin{tabular}{|c|c|c|c|c|c|}
\hline Product & Raw Materials & Product Form & Microorganisms Involved & Country/Region & Reference \\
\hline \multicolumn{6}{|l|}{ Cereal-Based } \\
\hline Tchoukoutou & Sorghum & Alcoholic beverage & $\begin{array}{l}\text { Candida albicans, Clavispora lusitaniae, Hanseniaspora } \\
\text { guillermondii, Hanseniaspora uvarum, Kluyveromyces } \\
\text { marxianus, Saccharomyces cerevisiae and Torulaspora } \\
\text { delbrueckii }\end{array}$ & Benin & $\begin{array}{l}\text { Greppi et al. [41]; Kayode } \\
\text { et al. [65]; Greppi et al. [66] }\end{array}$ \\
\hline Ting & Sorghum & Porridge & $\begin{array}{l}\text { Lacticaseibacillus casei, Lacticaseibacillus rhamnosus, } \\
\text { Lactiplantibacillus plantarum, Latilactobacillus curvatus, } \\
\text { Lentilactobacillus parabuchneri, Limosilactobacillus } \\
\text { fermentum, Limosilactobacillus reuteri, Loigolactobacillus } \\
\text { coryniformis and Schleiferilactobacillus harbinensis }\end{array}$ & Botswana, South Africa & $\begin{array}{l}\text { Madoroba et al. [67]; } \\
\text { Madoroba et al. [68]; } \\
\text { Sekwati-Monang and Gänzle } \\
\text { [69]; Adebo et al. [70] }\end{array}$ \\
\hline Tobwa & Maize & Beverage & LAB & Zimbabwe & Blandino et al. [3] \\
\hline Togwa & $\begin{array}{l}\text { Maize flour or finger } \\
\text { millet malt }\end{array}$ & & $\begin{array}{l}\text { Lactobacillus spp., Candida spp. and Saccharomyces } \\
\text { cerevisiae }\end{array}$ & Tanzania & Marsh et al. [21] \\
\hline Uji & Sorghum & Porridge & $\begin{array}{l}\text { Lactiplantibacillus plantarum, Lactobacillus cellobiosus, } \\
\text { Limosilactobacillus fermentum, Pediococcus acidilactici } \\
\text { and Pediococcus pentosaceus }\end{array}$ & East Africa & Blandino et al. [3]; Nout [71] \\
\hline Umqombothi & Sorghum/maize & Beverage & Lactobacillus spp. and Saccharomyces cerevisiae & Southern Africa & $\begin{array}{l}\text { Katongole [72]; Van Der Walt } \\
\text { [73] }\end{array}$ \\
\hline
\end{tabular}

Table 2. Some legume fermented products and associated microorganisms responsible for fermentation.

\begin{tabular}{|c|c|c|c|c|c|}
\hline Product & Raw Materials & Product Form & Microorganisms Involved * & Country/Region & Reference \\
\hline \multicolumn{6}{|l|}{ Legume-Based } \\
\hline Aakhone/Axone & Soybean & Condiment & Bacillus subtilis and Proteus mirabilis & India & Singh et al. [74] \\
\hline Amriti & Black lentils & Snack & LAB and yeasts & India & $\begin{array}{l}\text { Steinkraus [22]; Hossain and } \\
\text { Kabir [75] }\end{array}$ \\
\hline Bedvin roti & $\begin{array}{l}\text { Black gram, opium } \\
\text { seeds or walnut }\end{array}$ & Snack & Not reported & India & Rawat et al. [76] \\
\hline Bekang & Soybean & Paste & $\begin{array}{l}\text { Bacillus amyloliquefaciens, Bacillus brevis, Bacillus circulans, Bacillus } \\
\text { coagulans, Bacillus licheniformis, Bacillus pumilus, Bacillus } \\
\text { sphaericus, Bacillus subtilis, Debaryomyces hansenii, Enterococcus } \\
\text { cecorum, Enterococcus durans, Enterococcus faecium, Enterococcus } \\
\text { hirae, Enterococcus raffinossus, Pichia burtonii, Proteus mirabilis, } \\
\text { Saccharomyces cerevisiae }\end{array}$ & India & Singh et al. [74]; Chettri [77] \\
\hline
\end{tabular}


Table 2. Cont.

\begin{tabular}{|c|c|c|c|c|c|}
\hline Product & Raw Materials & Product Form & Microorganisms Involved * & Country/Region & Reference \\
\hline \multicolumn{6}{|l|}{ Legume-Based } \\
\hline Bhallae & Black gram & Side dish & $\begin{array}{l}\text { Bacillus subtilis, Candida curvata, Candida famata, Candida } \\
\text { membraneafaciens, Candida variovaarai, Cryptococcus humicoius, } \\
\text { Debaryomyces hansenii, Enterococcus faecalis, Geotrichum candidum, } \\
\text { Hansenula anomala, Hansenula polymorpha, Kluyveromyces } \\
\text { marxianus, Leuconostoc mesenteroides, Limosilactobacillus fermentum, } \\
\text { Pediococcus membranaefaciens, Rhizopus marina, Saccharomyces } \\
\text { cerevisiae, Trichosporon beigelii, Trichosporon pullulans and Wingea } \\
\text { robertsii }\end{array}$ & India & Rani and Soni [78] \\
\hline Chee-fan & Soybean wheat curd & Cheese-like & $\begin{array}{l}\text { Aspergillus glaucus and Mucor spp. } \\
\text { Bacillus amyloliquefaciens, Bacillus cereus, Bacillus subtilis, Pantoea }\end{array}$ & China & Blandino et al. [3] \\
\hline Cheonggukjang & Soybean & Meal, dish & $\begin{array}{l}\text { agglomerans, Pantoega ananatis, Enterococcus spp., Pseudomonas } \\
\text { spp. and Rhodococcus spp. }\end{array}$ & Korea & Shin et al. [79] \\
\hline Dalbari (Urad dalbari) & Lentil & Snack & Not reported & India & Sha et al. [80] \\
\hline Dawadawa & $\begin{array}{l}\text { Bambara groundnut } \\
\text { and locust bean }\end{array}$ & Condiment & Bacillus licheniformis, Bacillus pumilus and Bacillus subtilis & $\begin{array}{l}\text { Central and West } \\
\text { Africa }\end{array}$ & $\begin{array}{l}\text { Amadi et al. [81]; Frias et al. } \\
\text { [82]; Akanni et al. [83] }\end{array}$ \\
\hline Dhokla & $\begin{array}{l}\text { Chickpeas, green } \\
\text { gram and rice }\end{array}$ & Snack & $\begin{array}{l}\text { Enterococcus faecalis, Leuconostoc mesenteroides, Limosilactobacillus } \\
\text { fermentum, Streptococcus faecalis, Torulaspora candida and } \\
\text { Torulaspora pullulans }\end{array}$ & India & $\begin{array}{l}\text { Blandino et al. [3]; } \\
\text { Frias et al. [82] }\end{array}$ \\
\hline Doenjang & Soybean & Soup & $\begin{array}{l}\text { Aspergillus oryzae, Bacillus licheniformis, Bacillus subtilis, } \\
\text { Debaryomyces hansenii, Enterococcus faecium, Lactobacillus spp., } \\
\text { Leuconostoc mesenteroides, Mucor plumbeus and Tetragenococcus } \\
\text { halophilus }\end{array}$ & Korea & $\begin{array}{l}\text { Shin et al. [79]; } \\
\text { Frias et al. [82] }\end{array}$ \\
\hline Dosa & $\begin{array}{l}\text { Black gram dhal } \\
\text { (Phaselus mango) and } \\
\text { rice }\end{array}$ & Pancake, snack & $\begin{array}{l}\text { Bacillus amyloliquefaciens, Enterococcus faecalis, Candida boidini, } \\
\text { Candida glabrata, Candida sake, Debaryomyces hansenii, Hansenula } \\
\text { polymorpha, Issatchenkia terricola, Lactobacillus delbrueckii, } \\
\text { Lactobacillus fermenti, Leuconostoc mesenteroides, Streptococcus } \\
\text { faecalis and Rhizopus graminis }\end{array}$ & India, Sri Lanka & Soni et al. [84] \\
\hline Douchi & Soybean & Condiment & $\begin{array}{l}\text { Aspergillus oryzae, Bacillus amyloliquefaciens, Bacillus subtilis, } \\
\text { Enterobacter spp., Pichia farinose, Pseudomonas spp., Saccharomyces } \\
\text { cerevisiae, Staphylococcus saprophyticus and Staphylococcus sciuri }\end{array}$ & China, Taiwan & $\begin{array}{l}\text { Zhang et al. [85]; } \\
\text { Chen et al. [86] }\end{array}$ \\
\hline Furu & Soybean curd & Condiment & $\begin{array}{l}\text { Bacillus firmus, Bacillus megaterium, Bacillus pumilus, Bacillus } \\
\text { stearothermophilus and Staphylococcus hominis }\end{array}$ & China & Sumino et al. [87] \\
\hline
\end{tabular}


Table 2. Cont.

\begin{tabular}{|c|c|c|c|c|c|}
\hline Product & Raw Materials & Product Form & Microorganisms Involved * & Country/Region & Reference \\
\hline \multicolumn{6}{|l|}{ Legume-Based } \\
\hline Gochujang & $\begin{array}{l}\text { Soybean and red } \\
\text { pepper }\end{array}$ & Seasoning & $\begin{array}{l}\text { Aspergillus spp., Bacillus amyloliquefacious, Bacillus liqueformis, } \\
\text { Bacillus subtilis, Bacillus velegensis, Candida lactis, Penicillium spp., } \\
\text { Rhizopus spp., spcecis of Oceanobacillus, Zygorouxii spp. and } \\
\text { Zygosaccharomyses spp. }\end{array}$ & Korea & Kim et al. [88]; Nam et al. [89] \\
\hline Hawaijar & Soybean & Meal, dish & $\begin{array}{l}\text { Alkaligenes spp., Bacillus amyloliquefaciens, Bacillus cereus, Bacillus } \\
\text { licheniformis, Bacillus subtilis, Proteus mirabilis, Providencia rettgers, } \\
\text { Staphylococcus aureus and Staphylococcus sciuri }\end{array}$ & India & $\begin{array}{l}\text { Singh et al. [74]; } \\
\text { Jeyaram et al. [90] }\end{array}$ \\
\hline Idli & Black gram and rice & Meal, dish & $\begin{array}{l}\text { Bacillus amyloliquefaciens, Candida versatilis, Enterococcus faecium, } \\
\text { Limosilactobacillus fermentum, Lactobacillus delbrueckii, Lactococcus } \\
\text { lactis, Loigolactobacillus coryniformis, Leuconostoc mesenteroides, } \\
\text { Pediococcus acidilactis, Pediococcus cerevisiae, Torulopsis spp. } \\
\text { Tricholsporon pullulans, Streptococcus lactis, Streptococcus faecalis } \\
\text { and yeast }\end{array}$ & $\begin{array}{l}\text { India, Malaysia, } \\
\text { Singapore, Sri Lanka }\end{array}$ & $\begin{array}{l}\text { Frias et al. [82]; } \\
\text { Sridevi et al. [91] }\end{array}$ \\
\hline Iru & Locust bean & Condiment & $\begin{array}{l}\text { Bacillus amyloliquefaciens, Bacillus atrophaeus, Bacillus fumus, } \\
\text { Bacillus licheniformis, Bacillus megaterium, Bacillus mojavensis, } \\
\text { Bacillus pumilus, Bacillus subtilis, Lysininbacillus sphaericus and } \\
\text { Staphylococcus saprophyticus }\end{array}$ & West Africa & $\begin{array}{l}\text { Odunfa and Oyewole [19]; } \\
\text { Meerak et al. [92] }\end{array}$ \\
\hline Kanjang & $\begin{array}{l}\text { Soybean, meju, salt } \\
\text { and water }\end{array}$ & Sauce & $\begin{array}{l}\text { Aspergillus oryzae, Bacillus citreus, Bacillus pumillus, Bacillus } \\
\text { subtilis, Saccharomyces rouxii and Sarcina mazima }\end{array}$ & Korea & Shin et al. [79] \\
\hline Kawal & $\begin{array}{l}\text { Leaves of legume } \\
\text { (Cassia spp.) }\end{array}$ & Meat substitute & $\begin{array}{l}\text { Bacillus subilis, Lactiplantibacillus plantarum, Propionibacterium spp. } \\
\text { and Staphylococcus sciuri, Yeasts } \\
\text { Aspergillus oryzae, Candida spp., Debaromyces spp., Pediococcus }\end{array}$ & Sudan & Dirar et al. [93] \\
\hline Kecap & Soybean and wheat & Sauce & $\begin{array}{l}\text { halophilus, Rhizopus oligosporus, Rhizopus oryzae, Staphylococcus } \\
\text { spp. and Sterigmatomyces spp. }\end{array}$ & Indonesia & Alexandraki et al. [94] \\
\hline Ketjap & Black soybean & Syrup & $\begin{array}{l}\text { Aspergillus flavus, Aspergillus oryzae, Rhizopus arrhizus, Rhizopus } \\
\text { oligosporus }\end{array}$ & Indonesia & Alexandraki et al. [94] \\
\hline Kinda & Locust bean & Condiment & $\begin{array}{l}\text { Bacillus amyloliquefaciens, Bacillus atrophaeus, Bacillus licheniformis, } \\
\text { Bacillus mojavensis, Bacillus pumilus, Bacillus subtilis and } \\
\text { Lysininbacillus sphaericus }\end{array}$ & Sierra Leone & Meerak et al. [92] \\
\hline Kinema & Soybean & Meal, dish & $\begin{array}{l}\text { Bacillus cereus, Bacillus circulans, Bacillus licheniformis, Bacillus } \\
\text { pumilus, Bacillus subtilis, Bacillus thuringiensis, Bacillus sphaericus, } \\
\text { Candida parapsilosis, Corynebacterium glutamicum, Enterococcus } \\
\text { faecium, Geotrichum candidum and Lactococcus lactis }\end{array}$ & Bhutan, India, Nepal & $\begin{array}{l}\text { Tamang [95]; } \\
\text { Kumar et al. [96] }\end{array}$ \\
\hline
\end{tabular}


Table 2. Cont.

\begin{tabular}{|c|c|c|c|c|c|}
\hline Product & Raw Materials & Product Form & Microorganisms Involved * & Country/Region & Reference \\
\hline \multicolumn{6}{|l|}{ Legume-Based } \\
\hline Khaman & $\begin{array}{l}\text { Bengal gram and } \\
\text { chickpeas }\end{array}$ & Snack & $\begin{array}{l}\text { Bacillus spp., Lactobacillus fermentum, Lactobacillus lactis, } \\
\text { Leuconostoc mesenteroides and Pediococcus acidilactici }\end{array}$ & India & Ramakrishnan [97] \\
\hline Koikuchi Shoyu & $\begin{array}{l}\text { Defatted soybean } \\
\text { flake, wheat, brine } \\
\text { and tane-koji }\end{array}$ & Soy sauce & $\begin{array}{l}\text { Aspergillus oryzae, Aspergillus sojae, Bacillus spp., Enterococcus } \\
\text { faecalis, Pediococcus halophilus, Torulopsis echellsii, Torulopsis } \\
\text { versatilis, Saccharomyces halomembransis and Saccharomyces rouxii }\end{array}$ & Japan & Sugawara [98] \\
\hline Maseura & Black gram & $\begin{array}{l}\text { Dry, ball-like, } \\
\text { brittle, condiment }\end{array}$ & $\begin{array}{l}\text { Bacllus laterosporus, Bacillus mycondes, Bacillus pumilida castellii, Enterococcus durans, Ligilactobacillus } \\
\text { salivarius, Limosilactobacillus fermentum, Pediococcus acidilactici, } \\
\text { Pediococcus pentosaceous, Pichia burtonii and Saccharomyces } \\
\text { cerevisiae }\end{array}$ & India, Nepal & Chettri and Tamang [99] \\
\hline Mashbari & Black gram and spices & Meal, dish & Bacillus spp. $\mathrm{A}_{94}$, Lactobacillus spp. and Saccharomyces cerevisiae & India & Sharma et al. [100] \\
\hline Masyaura & $\begin{array}{l}\text { Black gram or green } \\
\text { gram }\end{array}$ & Side dish & $\begin{array}{l}\text { Aspergillus niger, Candida versatilis, Cladosporium spp., } \\
\text { Lactobacillus spp., Pediococcus acidilactici, Pediococcus pentosaceus, } \\
\text { Penicillium spp. and Saccharomyces cerevisiae }\end{array}$ & India, Nepal & $\begin{array}{l}\text { Dahal et al. [101]; } \\
\text { Dahal et al. [102] }\end{array}$ \\
\hline Meitauza & Soybean & Meal, dish & $\begin{array}{l}\text { Actinomucor elegans, Aspergillus oryzae, Bacillus subtilis, Mucor } \\
\text { meitauza and Rhizopus oligosporus }\end{array}$ & China, Taiwan & Zhu et al. [103] \\
\hline Меји & Soybean & Condiment & $\begin{array}{l}\text { Aspergillus flavus, Aspergillus fumigatus, Aspergillus niger, } \\
\text { Aspergillus oryzae, Aspergillus retricus, Aspergillus spinosa, } \\
\text { Aspergillus terreus, Aspergillus wentii, Bacillus citreus, Bacillus } \\
\text { circulans, Bacillus licheniformis, Bacillus megaterium, Bacillus } \\
\text { mesentricus, Bacillus subtilis, Bacillus pumilis, Botrytis cineara, } \\
\text { Candida edax, Candida incommenis, Candida utilis, Hansenula } \\
\text { anomala, Hansenula capsulata, Hansenula holstii, Lactobacillus spp., } \\
\text { Mucor adundans, Mucor circinelloides, Mucor griseocyanus, Mucor } \\
\text { hiemalis, Mucor jasseni, Mucor racemosus, Pediococcus acidilactici, } \\
\text { Penicillium citrinum, Penicillium griseopurpureum, Penicillium } \\
\text { griesotula, Penicillium kaupscinskii, Penicillium lanosum, Penicillium } \\
\text { thomii, Penicillium turalense, Rhizopus chinensis, Rhizopus nigricans, } \\
\text { Rhizopus oryzae, Rhizopus sotronifer, Rhodotorula flaca, Rhodotorula } \\
\text { glutinis, Saccharomyces exiguus, Saccharomyces cerevisiae, } \\
\text { Saccharomyces kluyveri, Zygosaccharomyces japonicus and } \\
\text { Zygosaccharomyces rouxii }\end{array}$ & Korea & Choi et al. [104] \\
\hline Miso & Soybean & Seasoning & $\begin{array}{l}\text { Aspergillus oryzae, Leuconostoc paramesenteroides, Micrococcus } \\
\text { halobius, Pediococcus acidilactici and Zygosaccharomyces rouxii }\end{array}$ & Japan & Asahara et al. [105] \\
\hline
\end{tabular}


Table 2. Cont.

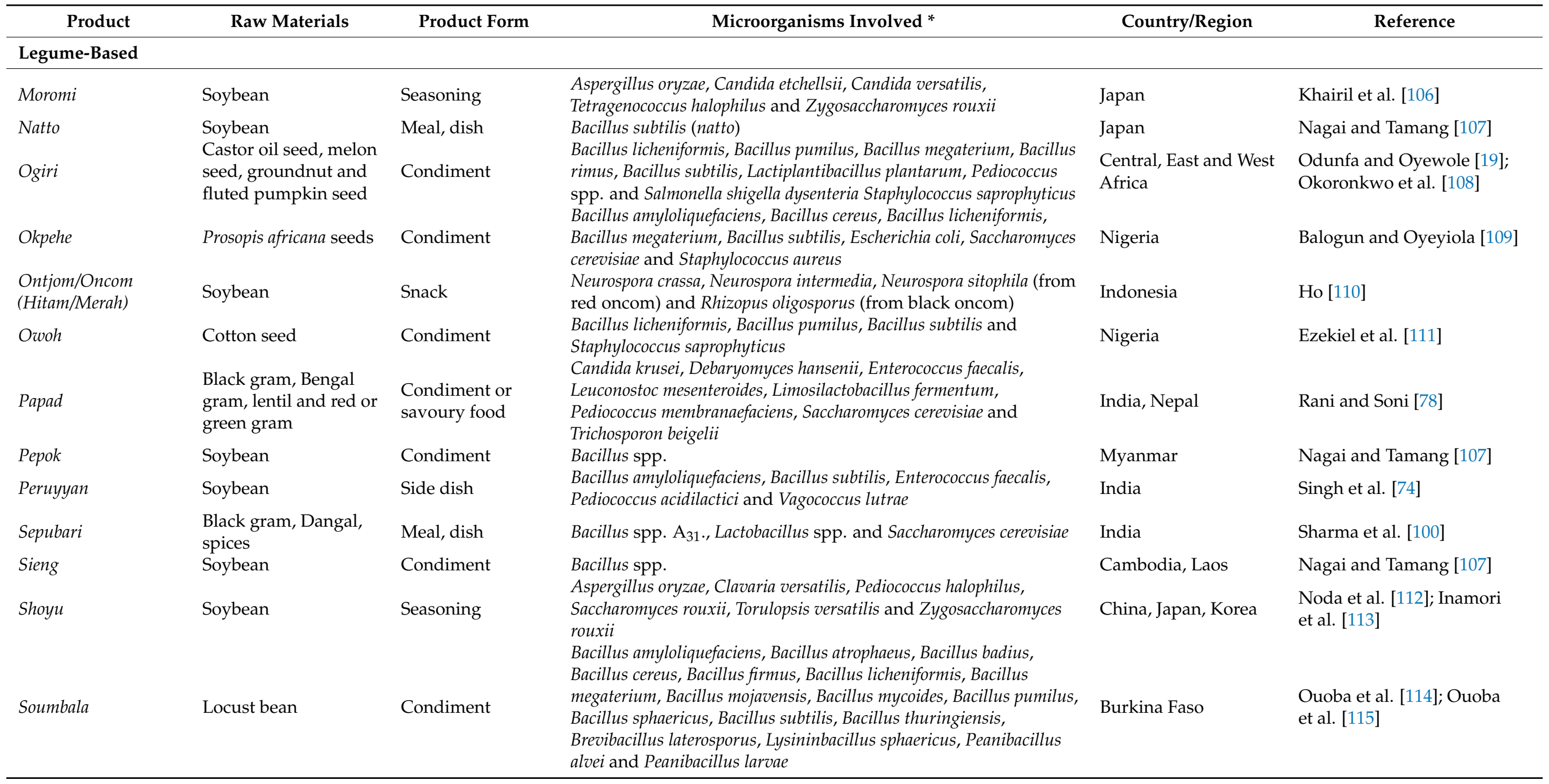


Table 2. Cont.

\begin{tabular}{|c|c|c|c|c|c|}
\hline Product & Raw Materials & Product Form & Microorganisms Involved * & Country/Region & Reference \\
\hline \multicolumn{6}{|l|}{ Legume-Based } \\
\hline Sufu & Soybean curd & Side dish & $\begin{array}{l}\text { Actinomucor elenans, Mucor corticolus, Mucor hiemalis, Mucor } \\
\text { praini, Monascus purpureus, Mucor racemosus, Mucor silvatixus, } \\
\text { Mucor subtilissimus and Rhizopus chinensis }\end{array}$ & China, Taiwan & $\begin{array}{l}\text { Han et al. [116]; Kanlayakrit } \\
\text { and Phromsak [117] }\end{array}$ \\
\hline Tauco & Soybean & Paste & $\begin{array}{l}\text { Aspergillus oryzae, Hansenula spp., Lactobacillus delbrueckii, } \\
\text { Rhizopus ologosporus, Rhizopus oryzae and Zygosaccharomyces soyae }\end{array}$ & Indonesia & Winarno et al. [118] \\
\hline Teliye mah & Black gram & Semi solid & Not reported & India & Thakur et al. [119] \\
\hline Tempe/Tempeh & Soybean & Side dish & $\begin{array}{l}\text { Aspergillus niger, Aspergillus oryzae, Citrobacter freundii, } \\
\text { Enterobacter cloacae, Klebsiella pneumoniae, Klebsiella pneumoniae } \\
\text { subspp. ozaenae, Lactiplantibacillus plantarum, Lactobacillus lactis, } \\
\text { Limosilactobacillus fermentum, Limosilactobacillus reuteri, Pseudomas } \\
\text { fluorescens as vitamin B12-producing bacteria, Rhizopus arrhizus, } \\
\text { Rhizopus oligosporus, Rhizopus oryzae and Rhizopus stolonifer }\end{array}$ & $\begin{array}{l}\text { Indonesia, Japan, } \\
\text { Korea, the } \\
\text { Netherlands, New } \\
\text { Guinea, Surinam }\end{array}$ & $\begin{array}{l}\text { Frias et al. [82]; Nout and } \\
\text { Kiers [120]; Jennessen et al. } \\
\text { [121] }\end{array}$ \\
\hline Tianmianjiang & Soybean & Sauce & Not reported & China, Korea & Kwon et al. [122] \\
\hline Thu nao & Soybean & $\begin{array}{l}\text { Condiment, side } \\
\text { dish }\end{array}$ & Bacillus pumilus, Bacillus subtilis and Lactobacillus spp. & Thailand & Chunhachart et al. [123] \\
\hline Tofu (stinky tofu) & Soybean & & $\begin{array}{l}\text { Bacillus spp., Enterococcus hermanniensis, Lactobacillus agilis, } \\
\text { Lactobacillus brevis, Lactobacillus buchneri, Lactobacillus crispatus, } \\
\text { Lactobacillus curvatus, Lactobacillus delbrueckii, Lactobacillus } \\
\text { farciminis, Lactobacillus fermentum, Lactobacillus pantheris, } \\
\text { Lactobacillus salivarius, Lactobacillus vaccinostercus, Lactococcus } \\
\text { lactis, Lactococcus spp., Leuconostoc camosum, Leuconostoc citreum, } \\
\text { Leuconostoc fallax, Leuconostoc lactis, Leuconostoc mesenteroides, } \\
\text { Leuconostoc pseudomesenteroides, Pediococcus acidilactici, } \\
\text { Streptococcus bovis, Streptococcus macedonicus, Weissella cibaria, } \\
\text { Weissella confusa, Weissella paramesenteroides and Weissella soli }\end{array}$ & China, Japan & Chao et al. [124] \\
\hline Toyo & $\begin{array}{l}\text { Soybean, salt, brown } \\
\text { sugar and wheat } \\
\text { starter }\end{array}$ & Cowpea sauce & $\begin{array}{l}\text { Aspergillus oryzae, Lactobacillus delbrueckii Hansenula anomala and } \\
\text { Hansenula subpelliculosa }\end{array}$ & Philippines & Alexandraki et al. [94] \\
\hline Tungrymbai & Soybean & Side dish & $\begin{array}{l}\text { Bacillus amyloliquefaciens, Bacillus licheniformis, Bacillus pumilus, } \\
\text { Bacillus subtilis, Enterococcus cecorum, Enterococcus durans, } \\
\text { Enterococcus faecium, Enterococcus hirae, Enterococcus raffinossus, } \\
\text { Levilactobacillus brevis, Debaryomyces hansenii, Pichia burtonii, } \\
\text { Saccharomyces cerevisiae and Vagococcus carniphilus }\end{array}$ & India & Singh et al. [74]; Chettri [77] \\
\hline Ugba & African oil bean & Condiment & $\begin{array}{l}\text { Bacillus spp., Micrococcus spp., Proteus spp., Pseudomonas spp. } \\
\text { and Staphylococcus spp. }\end{array}$ & Nigeria & Okorie and Olasupo [125] \\
\hline
\end{tabular}


Table 2. Cont.

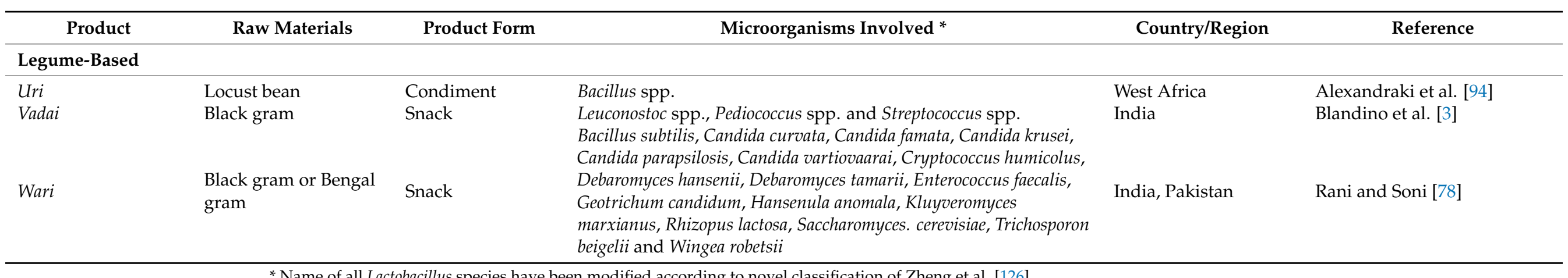

* Name of all Lactobacillus species have been modified according to novel classification of Zheng et al. [126]. 


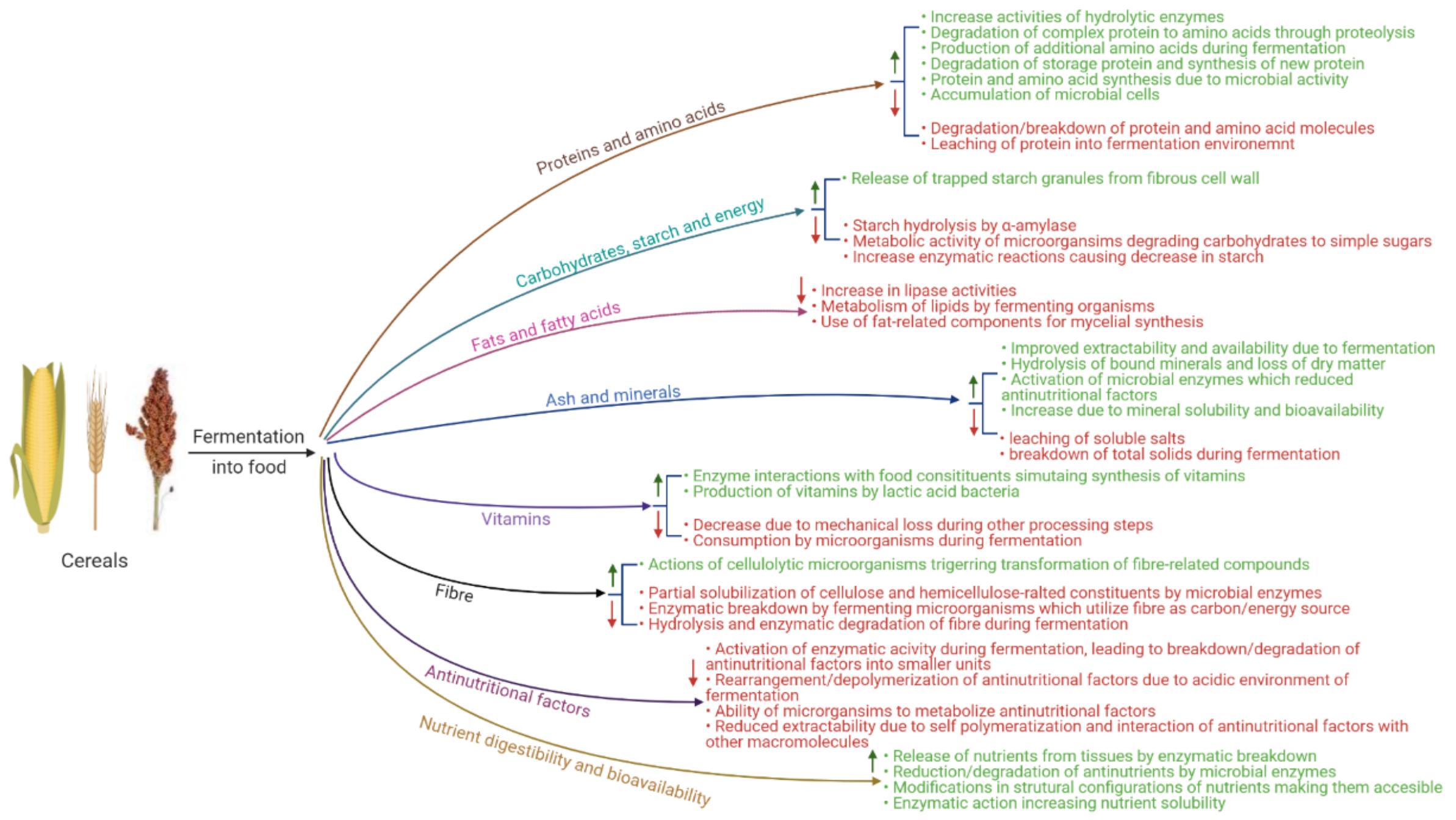

Figure 1. A summarized mechanisms of nutrient modifications in fermented cereals. 


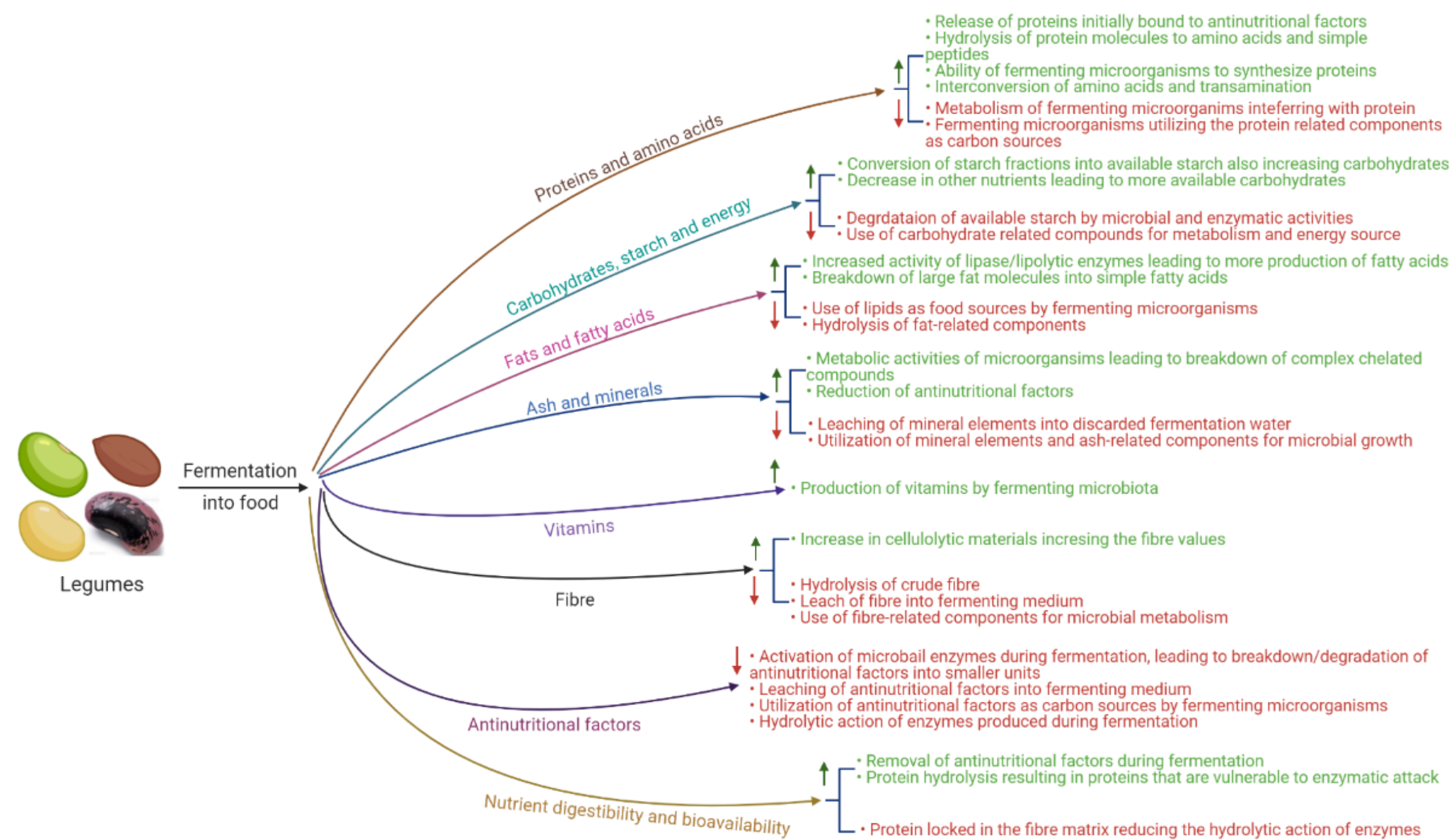

Figure 2. A summarized mechanisms of nutrient modifications in fermented legumes. 
Legumes are excellent sources of good-quality proteins and are rich in essential AAs. Fermentation increases the amount of free AA contents in legume-based products, depending on the legume species and cultivars [141], and such an increase could be of advantage in supplementing the nutrients obtained from other food crops and assisting people suffering from protein deficiency attributed to the maintenance and growth of the body. The fermentation of Bambara groundnuts into unhulled dawadawa (a fermented condiment) increased the protein content by approximately $18 \%$, and this was attributed to the release of proteins initially bound to the antinutritional factors [142]. The mechanism of the protein increase in this study was also ascribed to an increase in the microbial mass resulting in an extensive hydrolysis of the protein molecules to AAs and other simple peptides. Additionally, in the same study, fermentation was observed to significantly increase all the essential AAs except for lysine and histidine. The trend observed for histidine and lysine was attributed to their distinct basic side chains (which contain nitrogen and resemble ammonia), possibly causing them to have reacted differently during fermentation [142]. Peas (Pisum sativum) fermented with Aspergillus niger NRRL 334 and Aspergillus oryzae NRRL 5590 for $6 \mathrm{~h}$ at $40{ }^{\circ} \mathrm{C}$ to obtain fermented pea protein-enriched flour through SSF led to an increase in protein $(0.5-15 \%)$ and AA $(1.8-29 \%)$ levels [11,143]. It was postulated that the increase in the level of protein was due to the fungi utilizing lipids and starch as well as the ability of these fungi species to produce proteins [11,143]. An increase in the protein (3-25\%) through the SSF of legume flours has also been previously reported [144-149], with these studies ascribing such increases to the synthesis of new proteins during fermentation, yeast proliferation, the loss of dry matter, net synthesis of protein by fermenting seeds, increase in fungal biomass that was produced from the fermenting microorganism and partial protein denaturation and $\mathrm{pH}$ decrease during fermentation. The mechanism of an increase in the protein content of lupin flours fermented with Aspergillus ficuum, Aspergillus sojae and their co-cultures could be linked to the microorganisms using the substrate as carbon and energy sources during SSF to produce fungal protein [150]. The formation of soluble products and monomers after fermentation, as well as the interconversion of AAs, was reported to have also enhanced AA levels by up to $13 \%$, though an AA decrease of between $0.3 \%$ and $16 \%$ was equally reported during the fermentation of African yam bean flour [149]. The increase in AAs might also be attributed to transamination or synthesis taking place during the SSF process $[11,143]$. Some anabolic processes leading to the build-up of polymer or microbial cell proliferation were also reported to have increased the protein content (5-94\%) of soymilk from soybeans [151].

Some studies have reported both an increase and a decrease in protein and AA levels during the fermentation of legumes. Difo et al. [146] recorded both an increase (12\%) as well as a decrease of $10 \%$ in protein in fermented Vigna racemose flour. Such a decrease was suggested to have been due to the metabolism of Aspergillus niger with respect to other compounds present in $V$. racemosa, and such a metabolism might have produced some compounds capable of interfering with the protein content. The decrease in AAs in a study by Kumitch et al. [143] over the fermentation time ( $6 \mathrm{~h})$ could have been due to the fungi utilizing these AAs and reducing the essential AAs further. Another study was conducted on the common bean (Phaseolus vulgaris) fermented with Limosilactobacillus fermentum for $72 \mathrm{~h}$ at $37^{\circ} \mathrm{C}$ to obtain fermented bean powder through $\mathrm{SmF}$, leading to an increase in protein (1\%) as well as an increase (1-20\%) and decrease (3-7\%) in AAs [152]. While the increase in AAs was linked to the synthesis of substances by bacteria present in the substrate, the decrease suggested their utilization by the bacteria [152]. The modification of nutritional constituents usually occurs simultaneously with one another. For example, the slight decrease in the crude protein of Aspergillus ficuum fermented lupin was suggested to be interrelated to the observed increase in soluble carbohydrate and starch [150]. Noting that food constituents exist together in a food matrix, it could be postulated that a greater dissolution of carbohydrate and starch led the "exposed" proteins to the fermenting organisms, leading to this reported decrease. Asensio-Grau et al. [153] attributed the modification of protein levels to the bioconversion of some carbohydrates 
into protein. The differences in the trend of modification (increase/decrease) of protein and AA compositions in fermented cereals and legumes could be associated with factors such as the fermentation conditions used (which differs), growth rate and metabolic capabilities of the microbiota, initial protein content and AA composition of the grains as well as the solubility and molecular structure of the inherent protein and AAs.

\subsection{Carbohydrate, Energy and Starch Fractions}

Fermentation is an exothermic metabolic process which involves the consumption of food nutrients through the activities of microorganisms (either native or deliberately introduced) that serve as fermenters. These organisms rely on the different nutrients of foods and favourable environmental conditions for their growth and metabolic activities, leading to their survival, proliferation and synthesis of by-products. Fermentation enriches cereal-based food in protein by removing part of the carbohydrates and helping in energy reduction during cooking $[153,200,201]$. The effect of fermentation on the carbohydrate, energy and starch contents of some cereal-based foods are presented in Table 3. Nnam and Obiakor [137] reported a progressive increase $(1.1-2.4 \%)$ and decrease $(0.3 \%)$ in carbohydrate contents of spontaneously fermented rice for $72 \mathrm{~h}\left(24 \mathrm{~h}\right.$ interval) at $28{ }^{\circ} \mathrm{C}$ and ascribed this to changes in the population of the fermenting organism, which could be as a result of continuously changing the fermentation environment, enabled through changes in acidity and chemical balances. A significant increase in the carbohydrate content was also reported in fermented pearl millet flour (3\%) [128], fermented oat flour (1\%) [130], fermented sorghum flour (0.9\%) [139] and ogi (5-6\%) [140]. Decreases in carbohydrate levels have also been reported in fura (0.7\%) [129], fermented sorghum flour (0.3-1\%) [132], fermented rice flour $(0.5-7 \%)$ [134], fermented sorghum flour [136], fermented maize flour (4\%) [156] and fermented pearl millet flour (3\%) [158], with the studies attributing these to the metabolic activity of microorganisms degrading carbohydrates into simple sugars for their growth, as well as hydrolyses of starch by $\alpha$-amylase. Increases in energy levels have been reported in fermented pearl millet flour (2\%) [128] as well as decreases in fermented maize dough (1.6\%) [138] and fermented sorghum flour (1.6\%) [139] with no mechanisms reported. An increase in the total starch of a fermented cereal starter (from barley and pea) through SSF was ascribed to the decline in amylase activity and the release of trapped starch granules from the fibrous cell wall structure (by crude multienzyme composed of non-starch polysaccharide-hydrolysing enzymes) [18]. Decreases in resistant (20.6-72.9\%) and total (12.2-16.8\%) starches in fermented sorghum flour were also associated with the natural fermentation of sorghum that led to increased enzymatic reactions [166]. 
Table 3. Influence of fermentation on the nutritional composition of some cereal-based products.

\begin{tabular}{|c|c|c|c|c|c|c|c|c|}
\hline Raw Material & $\begin{array}{c}\text { Fermentation } \\
\text { Type }\end{array}$ & $\begin{array}{l}\text { Fermentation } \\
\text { Form }\end{array}$ & $\begin{array}{l}\text { Fermentation } \\
\text { Conditions }\end{array}$ & Product & $\begin{array}{c}\text { Modification(s) in } \\
\text { Nutritional } \\
\text { Constituents }\end{array}$ & $\begin{array}{l}\text { Percentage } \\
\text { Difference }\end{array}$ & Key Mechanism(s) Involved & Reference \\
\hline $\begin{array}{l}\text { Barley (Hordeum } \\
\text { vulgare) and pea } \\
\text { (Pisum sativum) }\end{array}$ & SSF & Spontaneous & $\begin{array}{l}24 \mathrm{~h} \text { at room } \\
\text { temperature }(\mathrm{RT}) \\
\text { for } 24 \mathrm{~h}, 72 \mathrm{~h} \text { at } \\
35-38^{\circ} \mathrm{C}, 168 \mathrm{~h} \text { at } \\
40-50{ }^{\circ} \mathrm{C}, 312 \mathrm{~h} \text { at } \\
53-60^{\circ} \mathrm{C}, 456 \mathrm{~h} \text { at } \\
35-40^{\circ} \mathrm{C}, 600 \mathrm{~h} \text { at } \\
28-34^{\circ} \mathrm{C} \text { and } \\
720 \mathrm{~h} \text { at } \mathrm{RT}\end{array}$ & $\begin{array}{l}\text { Cereal } \\
\text { starter }\end{array}$ & $\begin{array}{l}\text { Initial decrease in } \\
\text { reducing sugar, } \\
\text { increase and } \\
\text { afterwards decrease. } \\
\text { Initial decrease in } \\
\text { total starch and } \\
\text { subsequent increase } \\
\text { afterwards. }\end{array}$ & $\begin{array}{l}63 \% \downarrow \text { in reducing sugar } \\
\text { and } 3 \% \uparrow \text { in total starch. }\end{array}$ & $\begin{array}{l}\text { Increase in total starch } \\
\text { ascribed to decline in amylase } \\
\text { activity and release of } \\
\text { trapped starch granules from } \\
\text { the fibrous cell wall structure. }\end{array}$ & Li et al. [18] \\
\hline $\begin{array}{l}\text { Linseed (Linum } \\
\text { usitatissimum) }\end{array}$ & $\mathrm{SmF}$ & $\begin{array}{l}\text { Controlled using } \\
\text { Lactobacillus } \\
\text { acidophilus } \\
\text { MTCC-10307, } \\
\text { Bacillus } \\
\text { mesentericus, } \\
\text { Saccharomyces } \\
\text { boulardii, S. } \\
\text { ellipsoideus and } \\
\text { LAB isolate }\end{array}$ & $48 \mathrm{~h}$ at $30^{\circ} \mathrm{C}$ & $\begin{array}{l}\text { Fermented } \\
\text { linseed } \\
\text { beverage }\end{array}$ & $\begin{array}{l}\text { Reduction in tannins } \\
\text { and cyanogenic } \\
\text { glycosides. }\end{array}$ & $\begin{array}{l}22-66 \% \downarrow \text { in tannins and } \\
8-66 \% \downarrow \text { in cyanogenic } \\
\text { glycosides. }\end{array}$ & $\begin{array}{l}\text { Reduction in cyanogenic } \\
\text { glycosides due to the } \\
\text { breakdown and degradation } \\
\text { of ANFs into smaller units by } \\
\text { the action of enzymes. }\end{array}$ & $\begin{array}{l}\text { Nivetha } \\
\text { et al. [154] }\end{array}$ \\
\hline $\begin{array}{l}\text { Maize (Zea mays } \\
\text { L.) Hudeiba } 1 \text { and } \\
\text { Mugtama } 45 \\
\text { cultivars }\end{array}$ & SmF & Spontaneous & $\begin{array}{l}0-32 \mathrm{~h}(8 \mathrm{~h} \\
\text { interval }) \text { at } 37{ }^{\circ} \mathrm{C}\end{array}$ & $\begin{array}{l}\text { Fermented } \\
\text { maize flour }\end{array}$ & $\begin{array}{l}\text { Increase in crude } \\
\text { protein, some } \\
\text { essential AAs and } \\
\text { IVPD. }\end{array}$ & $\begin{array}{l}0.5-5 \% \uparrow \text { and } 0.1 \% \downarrow \text { in } \\
\text { crude protein, } \\
0.95-44 \% \uparrow \text { and } 9-16 \% \downarrow \\
\text { in essential AAs, } \\
3-21 \% \uparrow \text { in IVPD for } \\
\text { Hudeiba } 1 . \\
0.41-5 \% \uparrow \text { in crude } \\
\text { protein, } 0.4-38 \% \uparrow \text { and } \\
3-47 \% \downarrow \text { in essential AAs } \\
\text { and } 19-45 \% \uparrow \text { in IVPD } \\
\text { for Mugtama } 45 .\end{array}$ & Not reported. & $\begin{array}{l}\text { Mohiedeen } \\
\text { et al. [155] }\end{array}$ \\
\hline
\end{tabular}


Table 3. Cont.

\begin{tabular}{|c|c|c|c|c|c|c|c|c|}
\hline Raw Material & $\begin{array}{c}\text { Fermentation } \\
\text { Type }\end{array}$ & $\begin{array}{l}\text { Fermentation } \\
\text { Form }\end{array}$ & $\begin{array}{l}\text { Fermentation } \\
\text { Conditions }\end{array}$ & Product & $\begin{array}{c}\text { Modification(s) in } \\
\text { Nutritional } \\
\text { Constituents }\end{array}$ & $\begin{array}{l}\text { Percentage } \\
\text { Difference }\end{array}$ & Key Mechanism(s) Involved & Reference \\
\hline Maize (Z. mays) & SmF & $\begin{array}{l}\text { LAB consortium } \\
\text { from maize and } \\
\text { sorghum }\end{array}$ & $\begin{array}{l}0-48 \mathrm{~h}(12 \mathrm{~h} \\
\text { interval) at RT }\end{array}$ & $\begin{array}{l}\text { Fermented } \\
\text { maize flour }\end{array}$ & $\begin{array}{l}\text { Decrease in lipid, } \\
\text { fibre and CHO. } \\
\text { Increase in ash, } \\
\text { protein, IVSD and } \\
\text { IVPD. }\end{array}$ & $\begin{array}{l}74 \% \downarrow \text { in crude fibre, } \\
11 \% \downarrow \text { in lipid, } 4 \% \downarrow \text { in } \\
\mathrm{CHO}, 67 \% \uparrow \text { in ash, } \\
37 \% \uparrow \text { in protein, } \\
114-146 \% \uparrow \text { in IVSD and } \\
34-44.7 \% \uparrow \text { in IVPD. }\end{array}$ & $\begin{array}{l}\text { Lipid reduction due to } \\
\text { metabolism of fatty acids and } \\
\text { glycerol by fermenting } \\
\text { organisms. Fibre reduction } \\
\text { due to enzymatic breakdown } \\
\text { utilization as carbon source. } \\
\text { Increase in IVSD attributed to } \\
\text { changes in endosperm } \\
\text { protein which increased } \\
\text { starch accessibility to } \\
\text { digestive enzymes. }\end{array}$ & $\begin{array}{l}\text { Ogodo } \\
\text { et al. [156] }\end{array}$ \\
\hline $\begin{array}{l}\text { Maize (Z. mays) } \\
\text { varieties } \\
\text { yellow-coloured } \\
\text { quality protein } \\
\text { maize and } \\
\text { yellow-coloured } \\
\text { normal maize }\end{array}$ & SmF & Spontaneous & $72 \mathrm{~h}$ at $\mathrm{RT}$ & $\begin{array}{l}\text { Maize ogi } \\
\text { flour }\end{array}$ & $\begin{array}{l}\text { Decrease in crude } \\
\text { protein, fat, fibre, } \\
\text { ash and most } \\
\text { minerals. } \\
\text { Increase in } \mathrm{CHO} \text {. }\end{array}$ & $\begin{array}{l}15-24 \% \downarrow \text { in protein, } \\
4.6-18 \% \downarrow \text { in fat, } \\
27.3-32 \% \downarrow \text { in ash, } \\
46-49.2 \% \downarrow \text { in crude } \\
\text { fibre, } 5.5-5.8 \% \uparrow \text { in } \mathrm{CHO}, \\
7-548 \% \uparrow \text { and } 21-96 \% \downarrow \\
\text { in minerals. }\end{array}$ & $\begin{array}{l}\text { Protein degradation of due to } \\
\text { leaching of protein into the } \\
\text { fermenting water and/or } \\
\text { action of degrading enzymes. }\end{array}$ & $\begin{array}{l}\text { Oladeji } \\
\text { et al. [140] }\end{array}$ \\
\hline $\begin{array}{l}\text { Maize (Z. mays) } \\
\text { ZM } 607 \text { and } \\
\text { Tamira Pool A9 } \\
\text { varieties }\end{array}$ & SmF & Spontaneous & $8 \mathrm{~h}$ at $\mathrm{RT}$ & $\begin{array}{l}\text { Fermented } \\
\text { maize flour }\end{array}$ & $\begin{array}{l}\text { Increase in vitamins } \\
\text { and protein. } \\
\text { Decrease in fat and } \\
\text { fibre content. }\end{array}$ & $\begin{array}{l}51-141 \% \uparrow \text { in protein, } \\
20-30 \% \downarrow \text { in fat, } 24-31 \% \downarrow \\
\text { in fibre and } 10 \text {-fold } \uparrow \text { in } \\
\text { niacin. }\end{array}$ & Not reported. & $\begin{array}{l}\text { Ongol et al. } \\
\text { [157] }\end{array}$ \\
\hline Oat (Avena sativa) & SSF & $\begin{array}{l}\text { Starter culture } \\
\text { with Pleurotus } \\
\text { ostreatus CS155 } \\
\text { strain }\end{array}$ & $\begin{array}{l}336 \text { h (14 days) at } \\
\text { RT }\end{array}$ & $\begin{array}{l}\text { Fermented } \\
\text { oat flour }\end{array}$ & $\begin{array}{l}\text { Decrease in } \\
\text { minerals, fibre and } \\
\text { tannin. Increase in } \\
\text { protein, fat, CHO, } \\
\text { IVPD, soluble } \\
\text { nitrogen and some } \\
\text { AAs. }\end{array}$ & $\begin{array}{l}6.6 \% \uparrow \text { in protein, } 97 \% \uparrow \\
\text { in fat, } 48 \% \downarrow \text { in minerals, } \\
22 \% \downarrow \text { in fibre, } 1 \% \uparrow \text { in } \\
\mathrm{CHO}, 11 \% \uparrow \text { in IVPD, } \\
49 \% \uparrow \text { in soluble } \\
\text { nitrogen, } 50 \% \downarrow \text { in } \\
\text { tannin, } 0.12-90 \% \uparrow \text { and } \\
2.4-33 \% \downarrow \text { in AAs. }\end{array}$ & $\begin{array}{l}\text { Protein increase attributed to } \\
\text { increase in AA synthesis. } \\
\text { Decrease in fibre due to } \\
\text { enzymatic action. Decrease in } \\
\text { tannin was due to action of a } \\
\text { tannase. }\end{array}$ & $\begin{array}{l}\text { Espinosa- } \\
\text { Páez et al. } \\
\text { [130] }\end{array}$ \\
\hline
\end{tabular}


Table 3. Cont.

\begin{tabular}{|c|c|c|c|c|c|c|c|c|}
\hline Raw Material & $\begin{array}{c}\text { Fermentation } \\
\text { Type }\end{array}$ & $\begin{array}{l}\text { Fermentation } \\
\text { Form }\end{array}$ & $\begin{array}{c}\text { Fermentation } \\
\text { Conditions }\end{array}$ & Product & $\begin{array}{c}\text { Modification(s) in } \\
\text { Nutritional } \\
\text { Constituents }\end{array}$ & $\begin{array}{l}\text { Percentage } \\
\text { Difference }\end{array}$ & Key Mechanism(s) Involved & Reference \\
\hline $\begin{array}{l}\text { Pearl millet } \\
\text { (Pennisetum } \\
\text { glaucum) }\end{array}$ & SmF & Spontaneous & $72 \mathrm{~h}$ at $28^{\circ} \mathrm{C}$ & $\begin{array}{l}\text { Fermented } \\
\text { pearl millet } \\
\text { flour }\end{array}$ & $\begin{array}{l}\text { Decrease in crude } \\
\text { fat and ash. Increase } \\
\text { in crude protein, } \\
\text { AAs, most minerals, } \\
\text { CHO, energy and } \\
\text { fibre. }\end{array}$ & $\begin{array}{l}24 \% \downarrow \text { in fat, } 10 \% \uparrow \text { in ash, } \\
6 \% \uparrow \text { in protein, } 6-78 \% \uparrow \\
\text { in amino acids, } 3 \% \uparrow \text { in } \\
\mathrm{CHO}, 2 \% \uparrow \text { in energy, } \\
6 \% \uparrow \text { in fibre, } 10-92 \% \uparrow \\
\text { and } 2-43 \% \downarrow \text { in minerals. }\end{array}$ & $\begin{array}{l}\text { Breakdown of lipids and } \\
\text { leaching of soluble inorganic } \\
\text { salts. Accumulation of } \\
\text { proteins, increased activities } \\
\text { of hydrolytic enzymes, } \\
\text { degradation of complex } \\
\text { proteins to AAs and } \\
\text { production of additional AAs. } \\
\text { Improvement in the } \\
\text { extractability of minerals via } \\
\text { synthesis and cell wall } \\
\text { solubilization. }\end{array}$ & $\begin{array}{l}\text { Adebiyi } \\
\text { et al. [128] }\end{array}$ \\
\hline $\begin{array}{l}\text { Pearl millet } \\
\text { (P. glaucum })\end{array}$ & SmF & Spontaneous & $72 \mathrm{~h}$ at $\mathrm{RT}$ & $\begin{array}{l}\text { Fermented } \\
\text { pearl millet } \\
\text { flour }\end{array}$ & $\begin{array}{l}\text { Decrease in ash, } \\
\text { fibre and CHO. } \\
\text { Increase in fat and } \\
\text { protein. }\end{array}$ & $\begin{array}{l}21 \% \downarrow \text { in ash, } 55 \% \downarrow \text { in } \\
\text { fibre, } 3 \% \downarrow \text { in } \mathrm{CHO}, \\
103 \% \uparrow \text { in fat and } 24 \% \uparrow \\
\text { in protein. }\end{array}$ & $\begin{array}{l}\text { Ash reduction due to } \\
\text { leaching of soluble inorganic } \\
\text { salts. Low crude fibre due to } \\
\text { enzymatic degradation. } \\
\text { Metabolic activity of } \\
\text { microorganisms and enzymes } \\
\text { on sugars caused CHO } \\
\text { decrease. }\end{array}$ & $\begin{array}{l}\text { Akinola } \\
\text { et al. [158] }\end{array}$ \\
\hline $\begin{array}{l}\text { Pearl millet } \\
\text { (P. glaucum })\end{array}$ & SmF & Spontaneous & $48 \mathrm{~h}$ at $32^{\circ} \mathrm{C}$ & $\begin{array}{l}\text { Fermented } \\
\text { instant fura }\end{array}$ & $\begin{array}{l}\text { Increase in crude fat, } \\
\text { protein, fibre and } \\
\text { most minerals. } \\
\text { Decrease in ash, } \\
\text { CHO and PA. }\end{array}$ & $\begin{array}{l}3 \% \uparrow \text { in fat, } 4 \% \uparrow \text { in } \\
\text { protein, } 8 \% \downarrow \text { in ash, } \\
0.9 \% \uparrow \text { in fibre, } 0.7 \% \downarrow \text { in } \\
\mathrm{CHO}, 100 \% \downarrow \text { in PA, } \\
3-33 \% \uparrow \text { and } 99 \% \downarrow \text { in } \\
\text { minerals. }\end{array}$ & $\begin{array}{l}\text { Decrease in CHO due to } \\
\text { increase in } \alpha \text {-amylase activity. } \\
\text { Increase in protein due to } \\
\text { excess production of some } \\
\text { AAs, degradation of storage } \\
\text { protein. Mineral increase } \\
\text { attributed to breakdown of } \\
\text { protein-mineral bonds. }\end{array}$ & $\begin{array}{l}\text { Inyang and } \\
\text { Zakari [129] }\end{array}$ \\
\hline
\end{tabular}


Table 3. Cont.

\begin{tabular}{|c|c|c|c|c|c|c|c|c|}
\hline Raw Material & $\begin{array}{c}\text { Fermentation } \\
\text { Type }\end{array}$ & $\begin{array}{l}\text { Fermentation } \\
\text { Form }\end{array}$ & $\begin{array}{c}\text { Fermentation } \\
\text { Conditions }\end{array}$ & Product & $\begin{array}{c}\text { Modification(s) in } \\
\text { Nutritional } \\
\text { Constituents }\end{array}$ & $\begin{array}{l}\text { Percentage } \\
\text { Difference }\end{array}$ & Key Mechanism(s) Involved & Reference \\
\hline $\begin{array}{l}\text { Pearl millet } \\
\text { (P. glaucum) }\end{array}$ & $\mathrm{SmF}$ & $\begin{array}{l}\text { Inoculated with } \\
\text { mixed culture } \\
\text { combinations of } \\
\text { yeasts and bacteria } \\
\text { (S. cerevisiae, S. } \\
\text { diastaticus, L. brevis } \\
\text { and L. fermentum) }\end{array}$ & $72 \mathrm{~h}$ at $30^{\circ} \mathrm{C}$ & $\begin{array}{l}\text { Fermented } \\
\text { pearl millet } \\
\text { flour }\end{array}$ & $\begin{array}{l}\text { Increase in IVSD } \\
\text { and IVPD. }\end{array}$ & $\begin{array}{l}247-362 \% \uparrow \text { in IVSD and } \\
54-77 \% \uparrow \text { in IVPD. }\end{array}$ & Not reported. & $\begin{array}{l}\text { Khetarpaul } \\
\text { and } \\
\text { Chauhan } \\
\text { [159] }\end{array}$ \\
\hline $\begin{array}{l}\text { Pearl millet } \\
\text { (P. glaucum) }\end{array}$ & $\mathrm{SmF}$ & Spontaneous & $\begin{array}{l}0-96 \mathrm{~h}(24 \mathrm{~h} \\
\text { interval) at } 20,30 \text {, } \\
40 \text { and } 50^{\circ} \mathrm{C}\end{array}$ & $\begin{array}{l}\text { Fermented } \\
\text { pearl millet } \\
\text { flour }\end{array}$ & $\begin{array}{l}\text { Initial decrease in } \\
\text { reducing minerals } \\
\text { increase and } \\
\text { afterwards decrease } \\
\text { in fermentation } \\
\text { conditions. }\end{array}$ & $\begin{array}{l}14-63 \% \uparrow \text { in calcium, } \\
7-159 \% \uparrow \text { in iron, } \\
9-102 \% \uparrow \text { in zinc, } 118 \% \uparrow \\
\text { in copper and } 49-102 \% \uparrow \\
\text { in manganese. }\end{array}$ & Not reported. & $\begin{array}{l}\text { Mahajan } \\
\text { and } \\
\text { Chauhan } \\
\text { [160] }\end{array}$ \\
\hline Rice (Oryza sativa) & $\mathrm{SmF}$ & $\begin{array}{l}\text { Spontaneous } \\
\text { using } 1 \% \text { baker's } \\
\text { yeast }\end{array}$ & $\begin{array}{l}\text { Optimum } \\
\text { conditions of } \mathrm{pH} \\
5.5 \text { for } 6.26 \mathrm{~h} \\
\text { at } 32{ }^{\circ} \mathrm{C}\end{array}$ & $\begin{array}{l}\text { Fermented } \\
\text { rice flour }\end{array}$ & $\begin{array}{l}\text { Increase in protein, } \\
\text { ash, minerals, some } \\
\text { vitamins, total } \\
\text { starch, resistant } \\
\text { starch, amylose } \\
\text { content, insoluble } \\
\text { and soluble fibre. } \\
\text { Decrease in lipids } \\
\text { and PA. }\end{array}$ & $\begin{array}{l}13 \% \uparrow \text { in protein, } 7 \% \uparrow \text { in } \\
\text { ash, } 0.8 \% \downarrow \text { in lipid, } \\
108 \% \uparrow \text { in soluble fibre, } \\
16 \% \uparrow \text { in insoluble fibre, } \\
39 \% \uparrow \text { in resistant starch, } \\
11 \% \downarrow \text { in total starch, } \\
1.8 \% \downarrow \text { in amylose } \\
\text { content, } 13-34 \% \uparrow \text { in } \\
\text { minerals, 3-3617\% } \% \text { and } \\
0.99-3.4 \% \downarrow \text { in vitamins } \\
\text { and } 41 \% \downarrow \text { in PA. }\end{array}$ & $\begin{array}{l}\text { Protein increase due to } \\
\text { accumulation of microbial } \\
\text { cells. Increase in ash related } \\
\text { to increased mineral } \\
\text { solubility and bioavailability. } \\
\text { Vitamin B increase due to } \\
\text { enzyme interactions and } \\
\text { release of the bound forms of } \\
\text { the vitamins. Decrease in } \\
\text { amylose content due to the } \\
\text { breakdown of its chain by } \\
\alpha \text {-amylase. }\end{array}$ & $\begin{array}{l}\text { Ilowefah } \\
\text { et al. [133] }\end{array}$ \\
\hline
\end{tabular}


Table 3. Cont.

\begin{tabular}{|c|c|c|c|c|c|c|c|c|}
\hline Raw Material & $\begin{array}{c}\text { Fermentation } \\
\text { Type }\end{array}$ & $\begin{array}{l}\text { Fermentation } \\
\text { Form }\end{array}$ & $\begin{array}{c}\text { Fermentation } \\
\text { Conditions }\end{array}$ & Product & $\begin{array}{c}\text { Modification(s) in } \\
\text { Nutritional } \\
\text { Constituents }\end{array}$ & $\begin{array}{l}\text { Percentage } \\
\text { Difference }\end{array}$ & Key Mechanism(s) Involved & Reference \\
\hline Rice (O. sativa) & SmF & $\begin{array}{l}\text { Controlled using } \\
1 \% \text { baker's yeast }\end{array}$ & $\begin{array}{l}\text { Optimum } \\
\text { conditions of } \mathrm{pH} \\
5.5 \text { for } 6.23 \mathrm{~h} \\
\text { at } 32{ }^{\circ} \mathrm{C}\end{array}$ & $\begin{array}{l}\text { Fermented } \\
\text { rice flour }\end{array}$ & $\begin{array}{l}\text { Increase in protein, } \\
\text { ash, minerals, some } \\
\text { vitamins and } \\
\text { insoluble and } \\
\text { soluble fibre. } \\
\text { Decrease in lipids } \\
\text { and PA. }\end{array}$ & $\begin{array}{l}9 \% \uparrow \text { in ash, } 13 \% \uparrow \text { in } \\
\text { protein, } 0.8 \% \downarrow \text { in lipid, } \\
17 \% \uparrow \text { in insoluble fibre, } \\
106 \% \uparrow \text { in soluble fibre, } \\
39 \% \downarrow \text { in PA, } 13-34 \% \uparrow \text { in } \\
\text { minerals, } \\
1.3-3617 \% \uparrow \text { and } \\
1.4-21 \% \downarrow \text { in vitamins. }\end{array}$ & $\begin{array}{l}\text { Increase in mineral contents } \\
\text { to reduction in PA. }\end{array}$ & $\begin{array}{l}\text { Ilowefah } \\
\text { et al. [161] }\end{array}$ \\
\hline $\begin{array}{l}\text { Rice (O. sativa) } \\
\text { bran }\end{array}$ & SSF & $\begin{array}{l}\text { Controlled using } \\
\text { Rhizopus oryzae } \\
\text { CCT } 7560\end{array}$ & $\begin{array}{l}0-120 \mathrm{~h}(24 \mathrm{~h} \\
\text { interval }) \text { at } 30^{\circ} \mathrm{C}\end{array}$ & $\begin{array}{l}\text { Fermented } \\
\text { rice bran }\end{array}$ & $\begin{array}{l}\text { Increase in ash, } \\
\text { protein fibre and a } \\
\text { decrease in lipids } \\
\text { after } 48 \mathrm{~h} \\
\text { fermentation. }\end{array}$ & $\begin{array}{l}1.1-56 \% \uparrow \text { in ash, } \\
11-57 \% \uparrow \text { in fibre, } \\
6.1-49 \% \uparrow \text { in protein, } \\
1.3-3.3 \% \uparrow \text { and } 23-51 \% \downarrow \\
\text { in lipid. }\end{array}$ & $\begin{array}{l}\text { Decrease in lipid was due to } \\
\text { use of fat-related components } \\
\text { for mycelial synthesis. }\end{array}$ & $\begin{array}{l}\text { Kupski } \\
\text { et al. [162] }\end{array}$ \\
\hline Rice (O. sativa) & SmF & $\begin{array}{l}\text { Spontaneous } \\
\text { (microflora) }\end{array}$ & $\begin{array}{l}24-72 \mathrm{~h}(24 \mathrm{~h} \\
\text { interval }) \text { at } 28^{\circ} \mathrm{C}\end{array}$ & $\begin{array}{l}\text { Fermented } \\
\text { rice flour }\end{array}$ & $\begin{array}{l}\text { Increase in protein } \\
\text { at } 24 \mathrm{~h} \text { and decrease } \\
\text { afterwards. } \\
\text { Decrease in } \mathrm{CHO} \text { at } \\
24 \mathrm{~h} \text { and increase } \\
\text { afterwards. } \\
\text { Decrease in fat, ash, } \\
\text { tannin and phytate. } \\
\text { Decrease and } \\
\text { increase in minerals } \\
\text { in fermentation } \\
\text { time. }\end{array}$ & $\begin{array}{l}36.6 \% \uparrow \text { and } 8.6-19.1 \% \downarrow \\
\text { in protein, } 0.3 \% \downarrow \text { and } \\
1.1-2.4 \% \uparrow \text { in CHO, } \\
16.4-81 \% \downarrow \text { in fat, } \\
16-75 \% \downarrow \text { in ash, } 50 \% \downarrow \text { in } \\
\text { tannin, } 19-69 \% \downarrow \text { in } \\
\text { phytate, } 3.8-100 \% \uparrow \text { and } \\
14-97.9 \% \downarrow \text { in minerals. }\end{array}$ & $\begin{array}{l}\text { Fat decrease related to } \\
\text { increase in lipase activity, ash } \\
\text { decrease due to loss of dry } \\
\text { matter. The increase and } \\
\text { decrease in the mineral linked } \\
\text { to metabolic activities of } \\
\text { fermenting organisms which } \\
\text { hydrolysed metal-phytate } \\
\text { complexes to release free } \\
\text { minerals. Tannin decrease } \\
\text { attributed to milling which } \\
\text { removed most of the } \\
\text { tannin-related fractions while } \\
\text { phytate reduction ascribed to } \\
\text { increased phytase activities. }\end{array}$ & $\begin{array}{l}\text { Nnam and } \\
\text { Obiakor } \\
\text { [137] }\end{array}$ \\
\hline
\end{tabular}


Table 3. Cont.

\begin{tabular}{|c|c|c|c|c|c|c|c|c|}
\hline Raw Material & $\begin{array}{c}\text { Fermentation } \\
\text { Type }\end{array}$ & $\begin{array}{l}\text { Fermentation } \\
\text { Form }\end{array}$ & $\begin{array}{c}\text { Fermentation } \\
\text { Conditions }\end{array}$ & Product & $\begin{array}{c}\text { Modification(s) in } \\
\text { Nutritional } \\
\text { Constituents }\end{array}$ & $\begin{array}{l}\text { Percentage } \\
\text { Difference }\end{array}$ & Key Mechanism(s) Involved & Reference \\
\hline $\begin{array}{l}\text { Rice }(O \text {. sativa }) \\
\text { Mentik wangi } \\
\text { susu, red cempo } \\
\text { merah and black } \\
\text { jowo melik } \\
\text { varieties }\end{array}$ & SSF & $\begin{array}{l}\text { Controlled using } \\
\text { R. oligosporus }\end{array}$ & $\begin{array}{l}0-72 \mathrm{~h}(24 \mathrm{~h} \\
\text { interval) at RT }\end{array}$ & $\begin{array}{l}\text { Fermented } \\
\text { de-husked } \\
\text { rice flour }\end{array}$ & $\begin{array}{l}\text { Initial increase in } \\
\text { ash, protein and fat } \\
\text { with a decrease and } \\
\text { increase afterwards. } \\
\text { Decrease in CHO. }\end{array}$ & 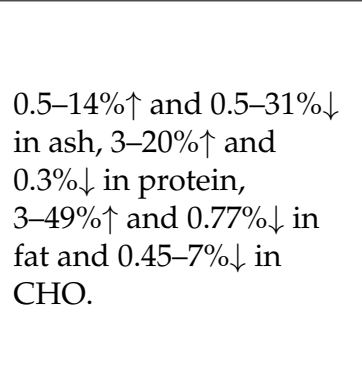 & $\begin{array}{l}\text { Protein increase due to } \\
\text { metabolic activity of fungi } \\
\text { while decrease due to protein } \\
\text { degradation to support } \\
\text { fungal growth. Increase in } \\
\text { ash due to phytase activation } \\
\text { and reduction in PA. } \\
\text { Decrease in fat and CHO due } \\
\text { to lipid and CHO } \\
\text { degradation, respectively. }\end{array}$ & $\begin{array}{l}\text { Suarti et al } \\
\text { [134] }\end{array}$ \\
\hline $\begin{array}{l}\text { Sorghum (Sorghum } \\
\text { bicolor) }\end{array}$ & SSF & $\begin{array}{l}\text { Spontaneous and } \\
\text { controlled using } L \text {. } \\
\text { Fermentum }\end{array}$ & $\begin{array}{l}72 \mathrm{~h} \text { at } 28^{\circ} \mathrm{C} \text { and } \\
24 \mathrm{~h} \text { at } 34^{\circ} \mathrm{C}\end{array}$ & Ting & $\begin{array}{l}\text { Decrease in tannin } \\
\text { contents. }\end{array}$ & 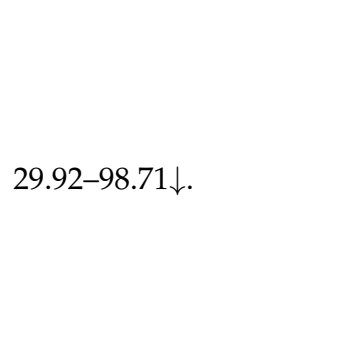 & $\begin{array}{l}\text { Tannin decrease due to } \\
\text { rearrangement and } \\
\text { depolymerization, reduced } \\
\text { extractability due to } \\
\text { self-polymerization, } \\
\text { interaction of tannin with } \\
\text { other macromolecules and } \\
\text { ability of LABs to metabolize } \\
\text { tannins. }\end{array}$ & $\begin{array}{l}\text { Adebo } \\
\text { et al. } \\
{[163-165]}\end{array}$ \\
\hline $\begin{array}{l}\text { Sorghum } \\
\text { (S. bicolor) }\end{array}$ & SSF & $\begin{array}{l}\text { Induced } \\
\text { fermentation (i.e., } \\
\text { back-slopping or } \\
\text { inoculum } \\
\text { enrichment) }\end{array}$ & $\begin{array}{l}0-36 \mathrm{~h}(4 \mathrm{~h} \\
\text { interval }) \text { at } 37^{\circ} \mathrm{C}\end{array}$ & $\begin{array}{l}\text { Fermented } \\
\text { sorghum } \\
\text { flour }\end{array}$ & $\begin{array}{l}\text { Increase in IVSD. } \\
\text { Decrease in total } \\
\text { starch and resistance } \\
\text { starch. }\end{array}$ & $\begin{array}{l}1.6-54 \% \uparrow \text { in IVSD, } \\
12.2-16.8 \% \downarrow \text { in total } \\
\text { starch and } 20.6-72.9 \% \downarrow \\
\text { in resistance starch. }\end{array}$ & $\begin{array}{l}\text { IVSD increase attributed to } \\
\text { changes in endosperm } \\
\text { protein fractions, while } \\
\text { decrease in total and resistant } \\
\text { starches due to natural } \\
\text { increased enzymatic } \\
\text { reactions. }\end{array}$ & $\begin{array}{l}\text { Elkhalifa } \\
\text { et al. [166] }\end{array}$ \\
\hline $\begin{array}{l}\text { Sorghum } \\
\text { (S. bicolor) } \\
\text { (HS-B67-2) }\end{array}$ & $\mathrm{SmF}$ & $\begin{array}{l}\text { Probiotic } \\
\text { micro-organism L. } \\
\text { acidophilus }\end{array}$ & $12 \mathrm{~h}$ at $37^{\circ} \mathrm{C}$ & $\begin{array}{l}\text { Sorghum } \\
\text { flour for } \\
\text { sorghum- } \\
\text { based food } \\
\text { mixture }\end{array}$ & $\begin{array}{l}\text { Decrease and } \\
\text { increase fibre } \\
\text { content. Increase in } \\
\text { vitamins content. }\end{array}$ & $\begin{array}{l}10 \% \downarrow \text { in total and } \\
\text { insoluble dietary fibre; } \\
49-69 \% \uparrow \text { in soluble fibre; } \\
21-50 \% \downarrow \text { in } \beta \text {-glucan. } \\
\uparrow 53,67 \text { and } 29 \% \text { in } \\
\text { thiamine, riboflavin and } \\
\text { niacin, respectively. }\end{array}$ & $\begin{array}{l}\text { Fibre decrease due to } \\
\text { increased activity of } \\
\text { hydrolysing enzymes. }\end{array}$ & $\begin{array}{l}\text { Jood et al. } \\
\text { [167] }\end{array}$ \\
\hline
\end{tabular}


Table 3. Cont.

\begin{tabular}{|c|c|c|c|c|c|c|c|c|}
\hline Raw Material & $\begin{array}{c}\text { Fermentation } \\
\text { Type }\end{array}$ & $\begin{array}{l}\text { Fermentation } \\
\text { Form }\end{array}$ & $\begin{array}{c}\text { Fermentation } \\
\text { Conditions }\end{array}$ & Product & $\begin{array}{c}\text { Modification(s) in } \\
\text { Nutritional } \\
\text { Constituents }\end{array}$ & $\begin{array}{l}\text { Percentage } \\
\text { Difference }\end{array}$ & Key Mechanism(s) Involved & Reference \\
\hline $\begin{array}{l}\text { Sorghum } \\
\text { (S. bicolor) (Gobiye } \\
\text { and 76T1\#23 } \\
\text { cultivars) }\end{array}$ & SmF & Spontaneous & $\begin{array}{l}0-48 \mathrm{~h}(12 \mathrm{~h} \\
\text { interval) at RT } \\
\text { at RT }\end{array}$ & $\begin{array}{l}\text { Fermented } \\
\text { sorghum } \\
\text { flours }\end{array}$ & $\begin{array}{l}\text { Increase in protein. } \\
\text { Decrease in fat, fibre, } \\
\text { ash, } \mathrm{CHO} \text {, phytate, } \\
\text { tannin and most } \\
\text { minerals. }\end{array}$ & $\begin{array}{l}4.2-16.3 \% \uparrow \text { in protein, } \\
2.5-16 \% \downarrow \text { in fat, } \\
20.8-40.4 \% \downarrow \text { in fibre, } \\
13.1-41.1 \% \downarrow \text { in ash, } \\
0.32-1.4 \% \downarrow \text { in CHO, } \\
12-70 \% \downarrow \text { in phytate, } \\
7.4-59 \% \downarrow \text { in tannin, } \\
0.13 \% \uparrow \text { and } 0.02-7.2 \% \downarrow \\
\text { in minerals. }\end{array}$ & $\begin{array}{l}\text { Protein increase attributed to } \\
\text { cells of fermenting } \\
\text { microorganisms, while } \\
\text { decrease in fibre was due to } \\
\text { partial solubilisation of } \\
\text { cellulose and hemicellulosic } \\
\text { type of material by microbial } \\
\text { enzymes. Reduction in } \\
\text { minerals ascribed to } \\
\text { utilization of hydrolysed } \\
\text { elements for their metabolic } \\
\text { activities and losses during } \\
\text { decantation. }\end{array}$ & $\begin{array}{l}\text { Mihiret } \\
\text { [132] }\end{array}$ \\
\hline $\begin{array}{l}\text { Sorghum } \\
\text { (S. bicolor) }\end{array}$ & SSF & Starter inoculum & $72 \mathrm{~h}$ at $\mathrm{RT}$ & $\begin{array}{l}\text { Fermented } \\
\text { sorghum } \\
\text { flour }\end{array}$ & $\begin{array}{l}\text { Reduction in ash, } \\
\text { protein, fat, energy, } \\
\text { polyphenols, } \\
\text { phytate and AAs. } \\
\text { Increase in IVPD, } \\
\text { CHO and some } \\
\text { minerals. }\end{array}$ & $\begin{array}{l}6 \% \downarrow \text { in ash, } 13 \% \downarrow \text { in } \\
\text { protein, } 7 \% \downarrow \text { in fat, } \\
0.9 \% \uparrow \text { in CHO, } 1.6 \% \downarrow \text { in } \\
\text { energy, } 6 \% \uparrow \text { in fibre, } \\
18 \% \downarrow \text { in polyphenols, } \\
22 \% \downarrow \text { in phytate, } 21 \% \uparrow \\
\text { in IVPD, } 0.15-63 \% \uparrow \text { and } \\
8.3-48 \% \downarrow \text { in minerals, } \\
4.2-54 \% \downarrow \text { in AAs, no } \\
\text { increase or decrease } \\
\text { in tannin }\end{array}$ & $\begin{array}{l}\text { IVPD increase due to ANF } \\
\text { reduction. }\end{array}$ & $\begin{array}{l}\text { Mohammed } \\
\text { et al. [139] }\end{array}$ \\
\hline
\end{tabular}


Table 3. Cont.

\begin{tabular}{|c|c|c|c|c|c|c|c|c|}
\hline Raw Material & $\begin{array}{c}\text { Fermentation } \\
\text { Type }\end{array}$ & $\begin{array}{l}\text { Fermentation } \\
\text { Form }\end{array}$ & $\begin{array}{l}\text { Fermentation } \\
\text { Conditions }\end{array}$ & Product & $\begin{array}{l}\text { Modification(s) in } \\
\text { Nutritional } \\
\text { Constituents }\end{array}$ & $\begin{array}{l}\text { Percentage } \\
\text { Difference }\end{array}$ & Key Mechanism(s) Involved & Reference \\
\hline $\begin{array}{l}\text { Sorghum } \\
\text { (S. bicolor) }\end{array}$ & SSF & $\begin{array}{l}\text { Controlled using } \\
\text { LAB consortium } \\
\text { from fermented } \\
\text { maize and } \\
\text { sorghum }\end{array}$ & $\begin{array}{l}0-48 \mathrm{~h}(12 \mathrm{~h} \\
\text { interval) at } \mathrm{RT}\end{array}$ & $\begin{array}{l}\text { Fermented } \\
\text { sorghum } \\
\text { flours }\end{array}$ & $\begin{array}{l}\text { Decrease in fat, } \\
\mathrm{CHO} \text { and fibre. } \\
\text { Increase in ash and } \\
\text { protein. }\end{array}$ & $\begin{array}{l}0.78-6.40 \% \uparrow \text { in ash, } \\
7.03-34.45 \% \uparrow \text { in protein, } \\
2.93-9.36 \% \downarrow \text { in fat, } \\
1.01-5.25 \% \downarrow \text { in CHO } \\
\text { and } \\
33-72 \% \downarrow \text { in crude fibre } \\
\text { for sorghum sample; } \\
1.84-5.62 \% \uparrow \text { in ash, } \\
7-32 \% \uparrow \text { in protein, } \\
4-10 \% \downarrow \text { in fat, } 1.22-5 \% \downarrow \\
\text { in CHO and } 19 \% \uparrow \text { and } \\
50-70 \% \downarrow \text { in crude fibre } \\
\text { for maize. }\end{array}$ & $\begin{array}{l}\text { Fat decrease could be } \\
\text { attributed to its use as energy } \\
\text { source and production of } \\
\text { aroma compounds through } \\
\text { the breakdown of fatty acids } \\
\text { and glycerol. Decrease in } \\
\text { CHO due to starch hydrolysis } \\
\text { by amylases, while protein } \\
\text { increase can be attributed to } \\
\text { activities of proteolytic } \\
\text { enzymes. Increase in ash } \\
\text { related to mineral increase. }\end{array}$ & $\begin{array}{l}\text { Ogodo } \\
\text { et al. [136] }\end{array}$ \\
\hline $\begin{array}{l}\text { Sorghum } \\
\text { (S. bicolor) }\end{array}$ & SSF & $\begin{array}{l}\text { Controlled using } \\
\text { L. plantarum }\end{array}$ & $48 \mathrm{~h}$ at $30^{\circ} \mathrm{C}$ & $\begin{array}{l}\text { Fermented } \\
\text { sorghum } \\
\text { flour }\end{array}$ & $\begin{array}{l}\text { Reduction in } \\
\text { phytates, tannins, } \\
\text { oxalate and HCN. }\end{array}$ & $\begin{array}{l}77 \% \downarrow \text { in phytate, } 96.7 \% \downarrow \\
\text { in tannin, } 67.85 \% \downarrow \text { in } \\
\text { oxalate and } 52.3 \% \downarrow \text { in } \\
\text { HCN }\end{array}$ & $\begin{array}{l}\text { Phytate and tannin reduction } \\
\text { due to microbial and } \\
\text { enzymatic activity. }\end{array}$ & $\begin{array}{l}\text { Ojha et al. } \\
\text { [168] }\end{array}$ \\
\hline $\begin{array}{l}\text { Sorghum } \\
\text { (S. bicolor) }\end{array}$ & SmF & Spontaneous & $72 \mathrm{~h}$ at $\mathrm{RT}$ & $\begin{array}{l}\text { Fermented } \\
\text { sorghum } \\
\text { flour }\end{array}$ & $\begin{array}{l}\text { Increase in protein, } \\
\text { ash and fat. } \\
\text { Decrease in } \mathrm{CHO}, \\
\text { fibre, tannin and } \\
\text { phytate. }\end{array}$ & $\begin{array}{l}34.2 \% \uparrow \text { in protein, } \\
25.7 \% \uparrow \text { in ash, } 13 \% \uparrow \text { in } \\
\text { fat, } 49 \% \downarrow \text { in fibre, } 17 \% \downarrow \\
\text { in CHO, } 45 \% \downarrow \text { in } \\
\text { phytate and } 56 \% \downarrow \text { in } \\
\text { tannin. }\end{array}$ & $\begin{array}{l}\text { ANF reduction due to the } \\
\text { ability of microbial action. }\end{array}$ & $\begin{array}{l}\text { Ojokoh } \\
\text { and } \\
\text { Eromosele } \\
{[169]}\end{array}$ \\
\hline $\begin{array}{l}\text { Sorghum } \\
\text { (S. bicolor) }\end{array}$ & SSF & Spontaneous & $\begin{array}{l}840 \mathrm{~h} \text { ( } 5 \text { weeks) } \\
\text { at RT }\end{array}$ & $\begin{array}{l}\text { Fermented } \\
\text { sorghum } \\
\text { spent } \\
\text { grains }\end{array}$ & $\begin{array}{l}\text { Increase in protein, } \\
\text { lipids and decrease } \\
\text { in fibre and ash. } \\
\text { Increase in } \\
\text { nitrogen-free extract } \\
\text { and minerals } \\
\text { (phosphorus and } \\
\text { calcium) and a } \\
\text { decrease afterwards. }\end{array}$ & $\begin{array}{l}28.7-34.8 \% \uparrow \text { in protein, } \\
66-69 \% \downarrow \text { in fibre, } \\
36-41.5 \% \uparrow \text { in lipid, } \\
13.6-23 \% \downarrow \text { in ash, } \\
42-47.8 \% \uparrow \text { in nitrogen } \\
\text { extract, } 19 \% \downarrow \text { and } 12 \% \uparrow \\
\text { in phosphorus and } \\
7.5 \% \downarrow \text { and } 50-97.5 \% \uparrow \text { in } \\
\text { calcium. }\end{array}$ & $\begin{array}{l}\text { Fibre decrease due to } \\
\text { breakdown of the cellulose } \\
\text { components by } \\
\text { microorganisms to utilizable } \\
\text { sugars. Protein increase due } \\
\text { to protein synthesis. }\end{array}$ & $\begin{array}{l}\text { Onyimba } \\
\text { et al. [135] }\end{array}$ \\
\hline
\end{tabular}


Table 3. Cont.

\begin{tabular}{|c|c|c|c|c|c|c|c|c|}
\hline Raw Material & $\begin{array}{c}\text { Fermentation } \\
\text { Type }\end{array}$ & $\begin{array}{l}\text { Fermentation } \\
\text { Form }\end{array}$ & $\begin{array}{l}\text { Fermentation } \\
\text { Conditions }\end{array}$ & Product & $\begin{array}{c}\text { Modification(s) in } \\
\text { Nutritional } \\
\text { Constituents }\end{array}$ & $\begin{array}{l}\text { Percentage } \\
\text { Difference }\end{array}$ & Key Mechanism(s) Involved & Reference \\
\hline $\begin{array}{l}\text { Sorghum } \\
\text { (S. bicolor) } \\
\text { Karamaka and } \\
\text { Mugud cultivar }\end{array}$ & SSF & Starter inoculum & $\begin{array}{l}0-16 \mathrm{~h}(2 \mathrm{~h} \\
\text { interval }) \text { at } \mathrm{RT}\end{array}$ & $\begin{array}{l}\text { Fermented } \\
\text { sorghum } \\
\text { flour }\end{array}$ & $\begin{array}{l}\text { Decrease in phytate } \\
\text { and tannin. Increase } \\
\text { in IVPD. }\end{array}$ & $\begin{array}{l}12.4-67.8 \% \downarrow \text { in phytate, } \\
12.7-67.3 \% \downarrow \text { in tannin } \\
\text { and } 0.49-31.3 \% \uparrow \text { in } \\
\text { IVPD. }\end{array}$ & $\begin{array}{l}\text { Phytate reduction due to } \\
\text { microbial and phytase } \\
\text { activity. }\end{array}$ & $\begin{array}{l}\text { Wedad } \\
\text { et al. [170] }\end{array}$ \\
\hline $\begin{array}{l}\text { Stale rice } \\
(\text { O. sativa })\end{array}$ & SSF & $\begin{array}{l}\text { Fermented using } \\
\text { Cordyceps sinensis }\end{array}$ & $\begin{array}{l}168 \mathrm{~h} \text { (7 days) } \\
\text { at } 25^{\circ} \mathrm{C}\end{array}$ & $\begin{array}{l}\text { Fermented } \\
\text { rice flour }\end{array}$ & $\begin{array}{l}\text { Increase in protein, } \\
\text { lipids, } C H O, A A s, \\
\text { vitamin } E \text {, dietary } \\
\text { fibre and } \beta \text { glucan. }\end{array}$ & $\begin{array}{l}60.7 \% \uparrow \text { in protein, } \\
252 \% \uparrow \text { in lipid, } 4.2 \% \uparrow \text { in } \\
\mathrm{CHO}, 576 \% \uparrow \text { in dietary } \\
\text { fibre, } 900 \% \uparrow \text { in } \beta \text { glucan, } \\
133 \% \uparrow \text { in vitamin E and } \\
83-28,471 \% \uparrow \text { in AAs. }\end{array}$ & $\begin{array}{l}\text { Increase in bioactivity and } \\
\text { AAs was attributed to } \\
\text { transformation of inherent } \\
\text { constituents and some } \\
\text { mycelia of } C \text {. sinensis. }\end{array}$ & $\begin{array}{l}\text { Zhang et al. } \\
\text { [171] }\end{array}$ \\
\hline Tef (Eragrostis tef) & $\mathrm{SmF}$ & $\begin{array}{l}\text { Back-slopping } \\
\text { using leftover } \\
\text { (ersho: produced } \\
\text { from spontaneous } \\
\text { traditional } \\
\text { fermentation) }\end{array}$ & $\begin{array}{l}\text { 1st stage: at RT for } \\
\text { 3-4 days; } 2 \text { nd } \\
\text { stage: } 2-3 \mathrm{~h}\end{array}$ & $\begin{array}{l}\text { Fermented } \\
\text { flour to } \\
\text { prepare } \\
\text { batter and } \\
\text { injera }\end{array}$ & $\begin{array}{l}\text { Decrease in vitamin } \\
\text { (folate content). }\end{array}$ & $\begin{array}{l}12 \% \downarrow \text { in folate content } \\
\text { in batter and } 34 \% \downarrow \text { in } \\
\text { folate content in injera. }\end{array}$ & $\begin{array}{l}\text { Reduced folate content due to } \\
\text { folate consumption by other } \\
\text { microorganisms or losses } \\
\text { during discarding the } \\
\text { supernatant. }\end{array}$ & $\begin{array}{l}\text { Tamene } \\
\text { et al. [172] }\end{array}$ \\
\hline
\end{tabular}


Table 4. Influence of fermentation on the nutritional composition of some legume-based products.

\begin{tabular}{|c|c|c|c|c|c|c|c|c|}
\hline Raw Material & $\begin{array}{c}\text { Fermentation } \\
\text { Type }\end{array}$ & $\begin{array}{l}\text { Fermentation } \\
\text { Form }\end{array}$ & $\begin{array}{c}\text { Fermentation } \\
\text { Conditions }\end{array}$ & Product & $\begin{array}{l}\text { Modification(s) in } \\
\text { Nutritional } \\
\text { Constituents }\end{array}$ & $\begin{array}{l}\text { Percentage } \\
\text { Difference }\end{array}$ & Key Mechanism(s) Involved & Reference \\
\hline $\begin{array}{l}\text { African oil bean } \\
\text { (Pentaclethra } \\
\text { macrophylla) }\end{array}$ & SSF & Spontaneous & $72 \mathrm{~h}$ at $\mathrm{RT}$ & $\begin{array}{l}\text { Fermented } \\
\text { African oil } \\
\text { bean flour }\end{array}$ & $\begin{array}{l}\text { Decrease in fibre, fat, } \\
\text { ash, } \mathrm{CHO} \text { and } \\
\text { energy. Increase in } \\
\text { protein. }\end{array}$ & $\begin{array}{l}20 \% \downarrow \text { in fibre, } 5 \% \downarrow \text { in fat, } \\
19.4 \% \downarrow \text { in ash, } 7 \% \downarrow \text { in } \\
\mathrm{CHO}, 26 \% \downarrow \text { in energy } \\
\text { and } 22 \% \uparrow \text { in protein. } \\
60-73 \% \downarrow \text { in } \mathrm{HCN} \text {, }\end{array}$ & $\begin{array}{l}\text { Protein increase due to } \\
\text { synthesis of new proteins. }\end{array}$ & $\begin{array}{l}\text { Akubor } \\
\text { and } \\
\text { Chukwu } \\
\text { [144] }\end{array}$ \\
\hline $\begin{array}{l}\text { African oil bean } \\
\text { (P. macrophylla) }\end{array}$ & SSF & Spontaneous & $12-48 \mathrm{~h}$ at $\mathrm{RT}$ & $\begin{array}{l}\text { Fermented } \\
u g b a\end{array}$ & $\begin{array}{l}\text { Decrease in ANFs, } \\
\text { some saturated and } \\
\text { unsaturated fatty } \\
\text { acids. }\end{array}$ & $\begin{array}{l}24-46 \% \downarrow \text { in phytate, } \\
71-79 \% \downarrow \text { in tannin, } \\
62-77 \% \downarrow \text { in oxalate, } \\
2-24 \% \uparrow \text { and } 2-18 \% \downarrow \text { in } \\
\text { fatty acids. }\end{array}$ & $\begin{array}{l}\text { ANFs' decrease attributed to } \\
\text { leaching during soaking and } \\
\text { enzymatic activities in the } \\
\text { microflora. }\end{array}$ & $\begin{array}{l}\text { Onwuliri } \\
\text { et al. [173] }\end{array}$ \\
\hline $\begin{array}{l}\text { African yam bean } \\
\text { (Sphenostylis } \\
\text { stenocarpa) }\end{array}$ & SSF & $\begin{array}{l}\text { Controlled using } \\
\text { S. cerevisiae }\end{array}$ & $24 \mathrm{~h}$ at $45^{\circ} \mathrm{C}$ & $\begin{array}{l}\text { Fermented } \\
\text { African } \\
\text { yam bean } \\
\text { flour }\end{array}$ & $\begin{array}{l}\text { Increase in crude } \\
\text { protein, ash, } \\
\text { minerals, some AAs } \\
\text { and IVPD. Decrease } \\
\text { in fat content, fibre, } \\
\text { CHO and ANFs (PA } \\
\text { and tannin). }\end{array}$ & $\begin{array}{l}17 \% \uparrow \text { in protein, } 14 \% \uparrow \\
\text { in ash, } 2-52 \% \uparrow \text { in } \\
\text { minerals, } 0.2-13 \% \uparrow \text { and } \\
0.3-16 \% \downarrow \text { in AAs, } \\
10 \% \uparrow \text { in IVPD, } \\
25 \% \downarrow \text { in fat, } 15 \% \downarrow \text { in } \\
\text { fibre, } 4 \% \downarrow \text { in CHO, } \\
40 \% \downarrow \text { in PA, } 21 \% \downarrow \text { in } \\
\text { tannin and } 58 \% \downarrow \text { in TIA. }\end{array}$ & $\begin{array}{l}\text { Enhanced AA levels due to } \\
\text { formation of soluble products } \\
\text { and monomers as well as } \\
\text { interconversion of AAs. IVPD } \\
\text { increase ascribed to proteolysis, } \\
\text { increased availability of AAs } \\
\text { and reduced ANFs. Decrease in } \\
\text { fat attributed to lipase activity } \\
\text { and use of lipids as food source } \\
\text { by fermenting organisms. } \\
\text { Decrease in fibre and CHO due } \\
\text { to enzymatic degradation of } \\
\text { fibre and use of CHO-related } \\
\text { compounds as energy source, } \\
\text { respectively. }\end{array}$ & $\begin{array}{l}\text { Chinma } \\
\text { et al. [149] }\end{array}$ \\
\hline
\end{tabular}


Table 4. Cont.

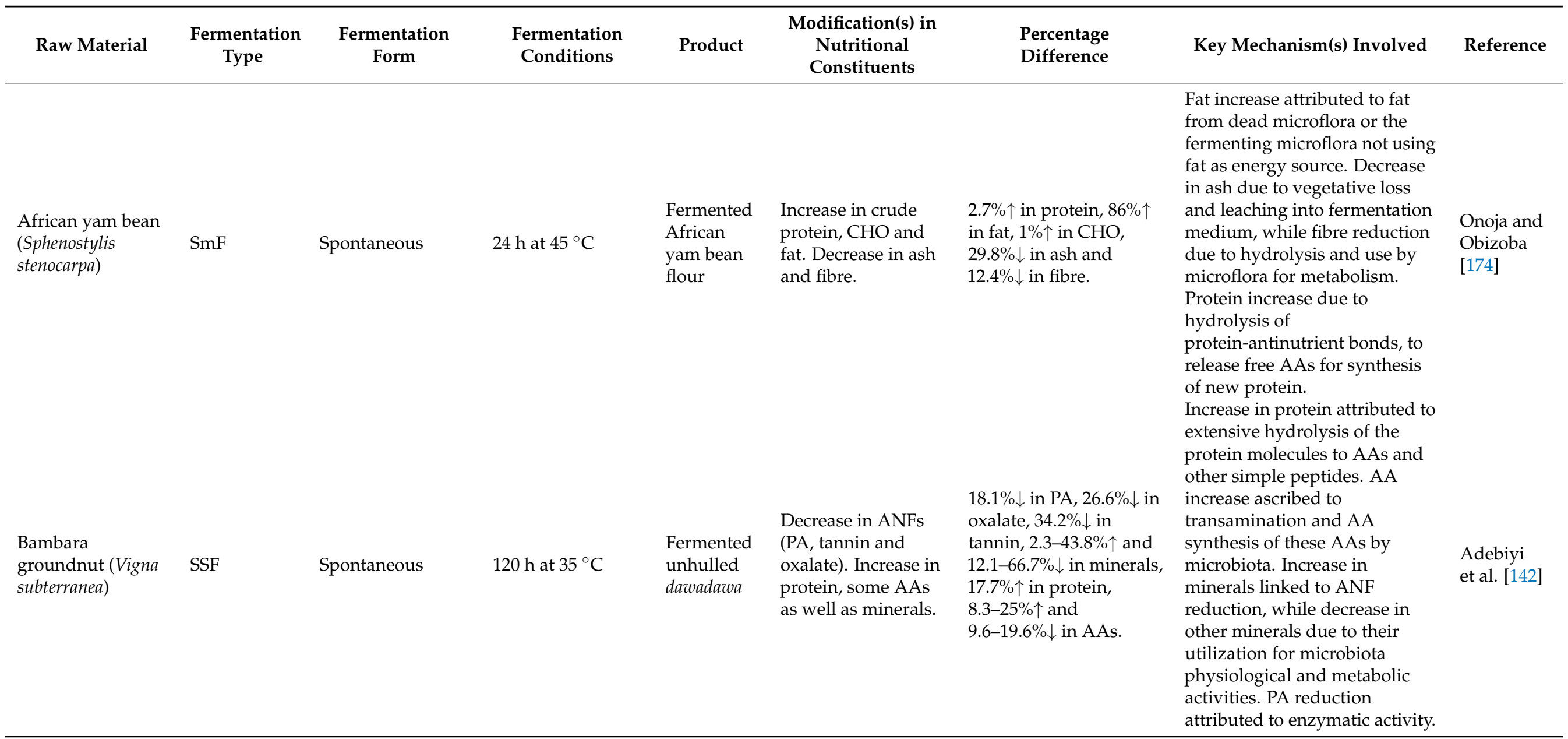


Table 4. Cont.

\begin{tabular}{|c|c|c|c|c|c|c|c|c|}
\hline Raw Material & $\begin{array}{c}\text { Fermentation } \\
\text { Type }\end{array}$ & $\begin{array}{l}\text { Fermentation } \\
\text { Form }\end{array}$ & $\begin{array}{c}\text { Fermentation } \\
\text { Conditions }\end{array}$ & Product & $\begin{array}{l}\text { Modification(s) in } \\
\text { Nutritional } \\
\text { Constituents }\end{array}$ & $\begin{array}{l}\text { Percentage } \\
\text { Difference }\end{array}$ & Key Mechanism(s) Involved & Reference \\
\hline $\begin{array}{l}\text { Bambara } \\
\text { groundnut }(V . \\
\text { subterranea) }\end{array}$ & SmF & Spontaneous & $48 \mathrm{~h}$ at $60^{\circ} \mathrm{C}$ & $\begin{array}{l}\text { Fermented } \\
\text { Bambara } \\
\text { groundnut } \\
\text { flour }\end{array}$ & $\begin{array}{l}\text { Increase in crude } \\
\text { protein, ash, fibre, } \\
\text { fat, } \mathrm{CHO} \text {, some AAs } \\
\text { and minerals } \\
\text { (except for sodium } \\
\text { and phosphorus). } \\
\text { Decrease in ANFs. }\end{array}$ & $\begin{array}{l}1.2 \% \uparrow \text { in protein, } 4.2 \% \downarrow \\
\text { in ash, } 4.1 \% \uparrow \text { in fibre, } \\
2 \% \uparrow \text { in fat, } 0.32 \% \uparrow \text { in } \\
\mathrm{CHO}, 0.96 \% \uparrow \text { in energy, } \\
6-107 \% \uparrow \text { and } 3-47 \% \downarrow \text { in } \\
\text { AAs, } 16 \% \downarrow \text { in oxalate, } \\
26 \% \downarrow \text { in TA, 39\% } \downarrow \text { in PA, } \\
42 \% \downarrow \text { in PP, 37\% } \downarrow \text { in } \\
\text { trypsin, } 4-27 \% \uparrow \text { and } \\
29-33 \% \downarrow \text { in minerals. }\end{array}$ & $\begin{array}{l}\text { ANF reduction ascribed to } \\
\text { biodegradation caused by } \\
\text { microbiota. }\end{array}$ & $\begin{array}{l}\text { Ijarotimi } \\
\text { and Esho } \\
{[175]}\end{array}$ \\
\hline $\begin{array}{l}\text { Bambara } \\
\text { groundnut } \\
\text { (V. subterranea) }\end{array}$ & SmF & $\begin{array}{l}\text { Controlled using } \\
\text { spore suspension } \\
\text { of } R \text {. oligosporous }\end{array}$ & $\begin{array}{l}0-72 \mathrm{~h}(12 \mathrm{~h} \\
\text { interval }) \text { at } 32{ }^{\circ} \mathrm{C}\end{array}$ & $\begin{array}{l}\text { Fermented } \\
\text { Bambara } \\
\text { groundnut } \\
\text { flour }\end{array}$ & Decrease in ANFs. & $\begin{array}{l}28-75 \% \downarrow \text { in tannin, } \\
36-52 \% \downarrow \text { in oxalate, } \\
22-96 \% \downarrow \text { in PT and } \\
42-87 \% \downarrow \text { in TIA. }\end{array}$ & $\begin{array}{l}\text { Tannin reduction caused by the } \\
\text { activity of polyphenol oxidase } \\
\text { and microflora. }\end{array}$ & $\begin{array}{l}\text { Ola and } \\
\text { Opaleye } \\
{[176]}\end{array}$ \\
\hline $\begin{array}{l}\text { Black beans } \\
\text { (Phaseolus vulgaris) }\end{array}$ & SSF & $\begin{array}{l}\text { Controlled using } P . \\
\text { ostreatus CS155 } \\
\text { strain }\end{array}$ & $\begin{array}{l}336 \mathrm{~h} \text { (14 days) } \\
\text { at } \mathrm{RT}\end{array}$ & $\begin{array}{l}\text { Fermented } \\
\text { black } \\
\text { beans flour }\end{array}$ & $\begin{array}{l}\text { Decrease in protein, } \\
\text { fat, minerals, fibre } \\
\text { and some AAs. } \\
\text { Increase in CHO, } \\
\text { IVPD, tannin and } \\
\text { soluble nitrogen. }\end{array}$ & $\begin{array}{l}3.5 \% \downarrow \text { in protein, } 20 \% \downarrow \\
\text { in fat, } 7 \% \downarrow \text { in minerals, } \\
59 \% \downarrow \text { in fibre, } 146 \% \uparrow \text { in } \\
\text { CHO, } 20 \% \downarrow \text { in IVPD, } \\
123 \% \uparrow \text { in soluble } \\
\text { nitrogen, } 20 \% \downarrow \text { in } \\
\text { tannin, } 2-139 \% \uparrow \text { and } \\
0.85-14 \% \downarrow \text { in AAs. }\end{array}$ & $\begin{array}{l}\text { Fibre decrease due to } \\
\text { enzymatic activity, which led to } \\
\text { conversion of resistant starches } \\
\text { to available starches and } \\
\text { subsequent increase in } \mathrm{CHO} \\
\text { contents. Tannin decrease } \\
\text { ascribed to fungus-producing } \\
\text { tannase. }\end{array}$ & $\begin{array}{l}\text { Espinosa- } \\
\text { Páez et al. } \\
{[130]}\end{array}$ \\
\hline $\begin{array}{l}\text { Black-eyed pea } \\
\text { (V. unguiculata) }\end{array}$ & SSF & $\begin{array}{l}\text { Controlled using } \\
\text { Aspergillus oryzae } \\
\text { (MTCC 3107) }\end{array}$ & $\begin{array}{l}0-96 \mathrm{~h}(24 \mathrm{~h} \\
\text { interval }) \text { at } 30{ }^{\circ} \mathrm{C}\end{array}$ & $\begin{array}{l}\text { Fermented } \\
\text { black-eyed } \\
\text { pea flour }\end{array}$ & $\begin{array}{l}\text { Increase in iron, zinc } \\
\text { and in vitro } \\
\text { bioavailability of } \\
\text { minerals (iron and } \\
\text { zinc). }\end{array}$ & $\begin{array}{l}11-16.8 \% \uparrow \text { in iron, } \\
24-36 \% \uparrow \text { in zinc, } \\
6-75 \% \uparrow \text { and } 8-106 \% \uparrow \text { in } \\
\text { in vitro bioavailability } \\
\text { of iron and zinc, } \\
\text { respectively. }\end{array}$ & $\begin{array}{l}\text { Increased mineral digestibility } \\
\text { and bioavailability attributed to } \\
\text { reduction in ANF and toxic } \\
\text { factors. }\end{array}$ & $\begin{array}{l}\text { Chawla } \\
\text { et al. [177] }\end{array}$ \\
\hline
\end{tabular}


Table 4. Cont.

\begin{tabular}{|c|c|c|c|c|c|c|c|c|}
\hline Raw Material & $\begin{array}{c}\text { Fermentation } \\
\text { Type }\end{array}$ & $\begin{array}{l}\text { Fermentation } \\
\text { Form }\end{array}$ & $\begin{array}{c}\text { Fermentation } \\
\text { Conditions }\end{array}$ & Product & $\begin{array}{l}\text { Modification(s) in } \\
\text { Nutritional } \\
\text { Constituents }\end{array}$ & $\begin{array}{l}\text { Percentage } \\
\text { Difference }\end{array}$ & Key Mechanism(s) Involved & Reference \\
\hline $\begin{array}{l}\text { Chickpea (Cicer } \\
\text { arietinum L.) }\end{array}$ & SSF & $\begin{array}{l}\text { Controlled using } \\
\text { R. oligosporus }\end{array}$ & $\begin{array}{l}\text { Optimum } \\
\text { conditions of } \\
51.3 \text { h at } 34.9{ }^{\circ} \mathrm{C}\end{array}$ & $\begin{array}{l}\text { Fermented } \\
\text { tempeh } \\
\text { flour }\end{array}$ & $\begin{array}{l}\text { Increase in crude } \\
\text { protein, true protein, } \\
\text { available lysine and } \\
\text { IVPD. Decrease in } \\
\text { lipid, ash, CHO, PA } \\
\text { and tannins. }\end{array}$ & $\begin{array}{l}25 \% \uparrow \text { in crude protein, } \\
15.2 \% \uparrow \text { in IVPD, } 30.5 \% \uparrow \\
\text { in true protein, } 40.5 \% \uparrow \\
\text { in available lysine, } \\
5.7 \% \downarrow \text { in lipid, } 39.4 \% \downarrow \\
\text { in ash, } 0.72 \% \downarrow \text { in CHO, } \\
89.9 \% \downarrow \text { in PA and } 88 \% \downarrow \\
\text { in tannin. }\end{array}$ & $\begin{array}{l}\text { Increase in IVPD and lysine } \\
\text { due to ANF elimination and } \\
\text { protein hydrolysis. }\end{array}$ & $\begin{array}{l}\text { Reyes- } \\
\text { Moreno } \\
\text { et al. [178] }\end{array}$ \\
\hline $\begin{array}{l}\text { Chickpea (Cicer } \\
\text { arietinum L.) }\end{array}$ & SSF & $\begin{array}{l}\text { Controlled using } \\
\text { Cordyceps militaris }\end{array}$ & $\begin{array}{l}168 \mathrm{~h} \text { (7 days) } \\
\text { at } 25^{\circ} \mathrm{C}\end{array}$ & $\begin{array}{l}\text { Fermented } \\
\text { chickpea } \\
\text { flour }\end{array}$ & $\begin{array}{l}\text { Increase in crude } \\
\text { protein, true protein, } \\
\text { fat, ash, IVPD and } \\
\text { AAs, except for } \\
\text { arginine. Decrease } \\
\text { in CHO. }\end{array}$ & $\begin{array}{l}19.4 \% \uparrow \text { in crude protein, } \\
20 \% \uparrow \text { in true protein, } \\
1.8 \% \uparrow \text { in fat, } 6.1 \% \uparrow \text { in } \\
\text { ash, } 6.7 \% \downarrow \text { in } \mathrm{CHO}, \\
4.4 \% \uparrow \text { in IVPD, } 3.7 \% \downarrow \\
\text { and } 7-27.6 \% \uparrow \text { in AAs. }\end{array}$ & $\begin{array}{l}\text { Protein increase due to } \\
\text { accumulation during } \\
\text { fermentation as well as } \\
\text { synthesis or transamination. } \\
\text { Increase in IVPD ascribed to } \\
\text { the unfolding of the proteins } \\
\text { and hydrolysis by proteases. } \\
\text { CHO reduction due to use for } \\
\text { fungal growth. }\end{array}$ & $\begin{array}{l}\text { Xiao et al. } \\
{[147]}\end{array}$ \\
\hline
\end{tabular}


Table 4. Cont.

\begin{tabular}{|c|c|c|c|c|c|c|c|c|}
\hline Raw Material & $\begin{array}{c}\text { Fermentation } \\
\text { Type }\end{array}$ & $\begin{array}{l}\text { Fermentation } \\
\text { Form }\end{array}$ & $\begin{array}{c}\text { Fermentation } \\
\text { Conditions }\end{array}$ & Product & $\begin{array}{c}\text { Modification(s) in } \\
\text { Nutritional } \\
\text { Constituents }\end{array}$ & $\begin{array}{l}\text { Percentage } \\
\text { Difference }\end{array}$ & Key Mechanism(s) Involved & Reference \\
\hline $\begin{array}{l}\text { Cowpea } \\
\text { (V. unguiculata) }\end{array}$ & SSF & $\begin{array}{l}\text { Spontaneous and } \\
\text { controlled using } \\
\text { A. niger }\end{array}$ & $48 \mathrm{~h}$ at $\mathrm{RT}$ & $\begin{array}{l}\text { Fermented } \\
\text { cowpea } \\
\text { flours }\end{array}$ & $\begin{array}{l}\text { Increase in protein. } \\
\text { Decrease in lipid, } \\
\text { ash, fibre, ANFs, } \\
\text { minerals, raffinose } \\
\text { and stachyose, } \\
\text { except for decrease } \\
\text { and increase } \\
\text { in CHO. }\end{array}$ & $\begin{array}{l}21.8-24.9 \% \uparrow \text { in protein, } \\
25.3-58.7 \% \downarrow \text { in lipid, } \\
11.8-63.3 \% \downarrow \text { in ash, } \\
17.3-28.8 \% \downarrow \text { in fibre, } \\
3.15 \% \downarrow \text { and } 6.9 \% \uparrow \text { in } \\
\text { CHO, 3.8-98.5\% } \downarrow \text { in } \\
\text { minerals, 28-99\% } \downarrow \text { in } \\
\text { ANFs, } 74.6-85 \% \downarrow \text { in } \\
\text { raffinose and } \\
59.5-99.3 \% \downarrow \text { in } \\
\text { stachyose. }\end{array}$ & $\begin{array}{l}\text { Increase in protein attributed to } \\
\text { increase in biomass and partial } \\
\text { protein denaturation. Decrease } \\
\text { in ash, lipid, CHO and fibre } \\
\text { linked to microbial metabolism. } \\
\text { ANF reduction attributed to } \\
\text { degradation by } \\
\text { microorganisms. }\end{array}$ & $\begin{array}{l}\text { Difo et al. } \\
\text { [146] }\end{array}$ \\
\hline $\begin{array}{l}\text { Cowpea }(V . \\
\text { sinensis L. var. } \\
\text { carilla) }\end{array}$ & $\mathrm{SmF}$ & $\begin{array}{l}\text { Spontaneous and } \\
\text { controlled using } L . \\
\text { plantarum }\end{array}$ & $48 \mathrm{~h}$ at $37^{\circ} \mathrm{C}$ & $\begin{array}{l}\text { Fermented } \\
\text { cowpea } \\
\text { flour }\end{array}$ & $\begin{array}{l}\text { Increase in } \\
\text { riboflavin, decrease } \\
\text { in ANFs (raffinose, } \\
\text { TIA and stachyose), } \\
\text { total starch, } \\
\text { available starch and } \\
\text { thiamine. }\end{array}$ & $\begin{array}{l}80 \% \downarrow \text { in raffinose, } 50 \% \downarrow \\
\text { in TIA, } 96 \% \downarrow \text { in } \\
\text { stachyose, } 5.8 \% \downarrow \text { in total } \\
\text { starch, } 5 \% \downarrow \text { in available } \\
\text { starch, } 69 \% \downarrow \text { in thiamine } \\
\text { and } 106 \% \uparrow \text { in riboflavin } \\
\text { for spontaneous } \\
\text { fermented sample; } \\
94 \% \uparrow \text { in riboflavin, } \\
43 \% \downarrow \text { in thiamine, } \\
6.2 \% \downarrow \text { in total starch, } \\
12 \% \downarrow \text { in available starch, } \\
27 \% \downarrow \text { in TIA, } 88.8 \% \downarrow \text { in } \\
\text { stachyose and } 68.6 \% \downarrow \text { in } \\
\text { raffinose for controlled } \\
\text { fermented sample. }\end{array}$ & Not reported. & $\begin{array}{l}\text { Doblado } \\
\text { et al. [179] }\end{array}$ \\
\hline $\begin{array}{l}\text { Cowpea }(V . \\
\text { sinensis var. } \\
\text { Orutico and } V \text {. } \\
\text { sinensis var. Tuy) }\end{array}$ & SSF & Spontaneous & $48 \mathrm{~h}$ at $42{ }^{\circ} \mathrm{C}$ & $\begin{array}{l}\text { Fermented } \\
\text { cowpea } \\
\text { seeds }\end{array}$ & $\begin{array}{l}\text { Decrease in } \\
\text { available starch and } \\
\text { mineral elements. }\end{array}$ & $\begin{array}{l}4.5-22.8 \% \downarrow \text { in starch, } \\
42.1 \% \downarrow \text { in ash and } \\
4.4-68.8 \% \downarrow \text { in mineral } \\
\text { contents. }\end{array}$ & $\begin{array}{l}\text { Degradation of available starch } \\
\text { by microbial and enzymatic } \\
\text { activities, water solubilization } \\
\text { and leaching of minerals into } \\
\text { steep water. }\end{array}$ & $\begin{array}{l}\text { Granito } \\
\text { et al. [180] }\end{array}$ \\
\hline
\end{tabular}


Table 4. Cont.

\begin{tabular}{|c|c|c|c|c|c|c|c|c|}
\hline Raw Material & $\begin{array}{c}\text { Fermentation } \\
\text { Type }\end{array}$ & $\begin{array}{l}\text { Fermentation } \\
\text { Form }\end{array}$ & $\begin{array}{l}\text { Fermentation } \\
\text { Conditions }\end{array}$ & Product & $\begin{array}{l}\text { Modification(s) in } \\
\text { Nutritional } \\
\text { Constituents }\end{array}$ & $\begin{array}{l}\text { Percentage } \\
\text { Difference }\end{array}$ & Key Mechanism(s) Involved & Reference \\
\hline $\begin{array}{l}\text { Cowpea }(V \text {. } \\
\text { unguiculata) }\end{array}$ & SSF & $\begin{array}{l}\text { Controlled using } \\
\text { R. microspoms }\end{array}$ & $\begin{array}{l}0-24 \mathrm{~h}(3 \mathrm{~h} \\
\text { interval }) \text { at } \mathrm{RT}\end{array}$ & $\begin{array}{l}\text { Fermented } \\
\text { cowpea } \\
\text { flour }\end{array}$ & $\begin{array}{l}\text { Increase in protein, } \\
\text { fat, ash and CHO. }\end{array}$ & $\begin{array}{l}2.3-8.8 \% \uparrow \text { in protein, } \\
100-133 \% \uparrow \text { in fat, } \\
30.8-33 \% \uparrow \text { in ash and } \\
1.7-5 \% \uparrow \text { in CHO. }\end{array}$ & $\begin{array}{l}\text { Ash increase linked to increase } \\
\text { in B vitamins. }\end{array}$ & $\begin{array}{l}\text { Prinyawiw- } \\
\text { atkul et al. } \\
{[181]}\end{array}$ \\
\hline $\begin{array}{l}\text { Guanacaste } \\
\text { (Enterolobium } \\
\text { cyclocarpum (Jacq.) } \\
\text { Griseb.) }\end{array}$ & SSF & $\begin{array}{l}\text { Controlled using } \\
\text { A. niger }\end{array}$ & $\begin{array}{l}0-28 \mathrm{~h}(7 \mathrm{~h} \\
\text { interval }) \text { at } 30{ }^{\circ} \mathrm{C}\end{array}$ & $\begin{array}{l}\text { Fermented } \\
\text { whole } \\
\text { leaves of } \\
\text { Enterolo- } \\
\text { bium } \\
\text { cyclo- } \\
\text { carpum }\end{array}$ & $\begin{array}{l}\text { Decrease in tannin, } \\
\text { saponin, PA, oxalate, } \\
\text { neutral detergent } \\
\text { fibre and acid } \\
\text { detergent fibre. } \\
\text { Increase in crude } \\
\text { protein and a } \\
\text { decrease afterwards. }\end{array}$ & $\begin{array}{l}13.3-42.7 \% \downarrow \text { in tannin, } \\
11.7-28.8 \% \downarrow \text { in saponin, } \\
10.1-25.4 \% \downarrow \text { in PA, } \\
6.6-26.5 \% \downarrow \text { in oxalate, } \\
7.2-14.4 \% \downarrow \text { in acid } \\
\text { detergent fibre, } \\
21.7-25.5 \% \downarrow \text { in neutral } \\
\text { detergent fibre, } \\
10.2-16.3 \% \uparrow \text { and } \\
1.3-8.7 \% \downarrow \text { in protein. }\end{array}$ & $\begin{array}{l}\text { Protein increase attributed to } \\
\text { addition of microbial protein } \\
\text { during fermentation. Decrease } \\
\text { in fibres is an indication of cell } \\
\text { wall presence. ANF decrease } \\
\text { ascribed to enzymatic activities. }\end{array}$ & $\begin{array}{l}\text { Ayuk et al. } \\
{[182]}\end{array}$ \\
\hline $\begin{array}{l}\text { Horse gram } \\
\text { (Macrotyloma } \\
\text { uniflorum) }\end{array}$ & $\mathrm{SmF}$ & Spontaneous & $48 \mathrm{~h}$ at $\mathrm{RT}$ & $\begin{array}{l}\text { Fermented } \\
\text { horse gram } \\
\text { flour }\end{array}$ & $\begin{array}{l}\text { Reduction in ANFs } \\
\text { (PA, tannin and } \\
\text { oxalate). }\end{array}$ & $\begin{array}{l}69.5 \% \downarrow \text { in PA, } 69.4 \% \downarrow \text { in } \\
\text { tannin and } 66.8 \% \downarrow \text { in } \\
\text { oxalate. }\end{array}$ & $\begin{array}{l}\text { ANF reduction attributed to } \\
\text { leaching, degradation through } \\
\text { enzyme activity and utilization } \\
\text { of ANF as a carbon source. }\end{array}$ & $\begin{array}{l}\text { Ojha et al. } \\
\text { [183] }\end{array}$ \\
\hline $\begin{array}{l}\text { Kidney bean } \\
\text { (Phaseolus vulgaris) }\end{array}$ & SSF & $\begin{array}{l}\text { Controlled using } P . \\
\text { ostreatus CS155 } \\
\text { strain }\end{array}$ & $\begin{array}{l}336 \mathrm{~h} \text { (14 days) } \\
\text { at RT }\end{array}$ & $\begin{array}{l}\text { Fermented } \\
\text { kidney } \\
\text { bean flour }\end{array}$ & $\begin{array}{l}\text { Decrease in fat, } \\
\text { minerals, CHO, } \\
\text { tannin and fibre. } \\
\text { Increase in protein, } \\
\text { IVPD, soluble } \\
\text { nitrogen and some } \\
\text { AAs. }\end{array}$ & $\begin{array}{l}13 \% \uparrow \text { in protein, } 10 \% \downarrow \\
\text { in fat, } 13 \% \downarrow \text { in minerals, } \\
16 \% \uparrow \text { in fibre, } 57 \% \uparrow \text { in } \\
\text { IVPD, } 100 \% \uparrow \text { in soluble } \\
\text { nitrogen, } 17 \% \downarrow \text { in CHO, } \\
34 \% \downarrow \text { in tannin, } \\
0.1-41 \% \uparrow \text { and } 0.4-18 \% \downarrow \\
\text { in AAs. }\end{array}$ & $\begin{array}{l}\text { Protein increase was attributed } \\
\text { to AA synthesis. Decrease in } \\
\text { tannin attributed to fungal } \\
\text { tannase. }\end{array}$ & $\begin{array}{l}\text { Espinosa- } \\
\text { Páez et al. } \\
{[130]}\end{array}$ \\
\hline
\end{tabular}


Table 4. Cont.

\begin{tabular}{|c|c|c|c|c|c|c|c|c|}
\hline Raw Material & $\begin{array}{c}\text { Fermentation } \\
\text { Type }\end{array}$ & $\begin{array}{l}\text { Fermentation } \\
\text { Form }\end{array}$ & $\begin{array}{c}\text { Fermentation } \\
\text { Conditions }\end{array}$ & Product & $\begin{array}{l}\text { Modification(s) in } \\
\text { Nutritional } \\
\text { Constituents }\end{array}$ & $\begin{array}{l}\text { Percentage } \\
\text { Difference }\end{array}$ & Key Mechanism(s) Involved & Reference \\
\hline $\begin{array}{l}\text { Kidney bean } \\
\text { (Phaseolus vulgaris) }\end{array}$ & SmF & Spontaneous & $16 \mathrm{~h}$ at $\mathrm{RT}$ & $\begin{array}{l}\text { Fermented } \\
\text { kidney } \\
\text { bean flours }\end{array}$ & $\begin{array}{l}\text { Decrease in protein, } \\
\text { ashes, fat, total } \\
\text { starch, available } \\
\text { starch, soluble fibre, } \\
\text { insoluble fibre, } \\
\text { minerals, TIA, } \\
\text { tannin and vitamin } \\
\text { B1 (thiamine). } \\
\text { Increase in resistant } \\
\text { starch, vitamin B2 } \\
\text { (riboflavin) and } \\
\text { IVPD. }\end{array}$ & $\begin{array}{l}1.7-14.5 \% \downarrow \text { in protein, } \\
3.8-7.7 \% \uparrow \text { in IVPD, } \\
0.63-2 \% \downarrow \text { in fat, } \\
5.4-16 \% \downarrow \text { in total starch, } \\
10-26.6 \% \downarrow \text { in available } \\
\text { starch, } 4.2-10.6 \% \uparrow \text { in } \\
\text { resistant starch, } \\
53-64 \% \downarrow \text { in ashes, } \\
4.5-25.8 \% \downarrow \text { in insoluble } \\
\text { fibre, 61-94\% } \% \text { in } \\
\text { soluble fibre, } 15-35 \% \downarrow \\
\text { in vitamin B1 } \\
\text { (thiamine), 16.7-33\%个 in } \\
\text { vitamin B2 (riboflavin), } \\
56-70.9 \% \downarrow \text { in TIA, } \\
60.6-69.7 \% \downarrow \text { in tannin } \\
\text { and } 1.8-68 \% \downarrow \text { in } \\
\text { minerals. }\end{array}$ & $\begin{array}{l}\text { Increase in vitamin due to } \\
\text { synthesis during fermentation. } \\
\text { Decrease in insoluble fibre } \\
\text { attributed to use of cellulose } \\
\text { and arabinoxilnase. }\end{array}$ & $\begin{array}{l}\text { Granito } \\
\text { et al. [184] }\end{array}$ \\
\hline $\begin{array}{l}\text { Lentils } \\
\text { (Lens culinaris) }\end{array}$ & SSF & $\begin{array}{l}\text { Controlled using } P \text {. } \\
\text { ostreatus strain }\end{array}$ & $\begin{array}{l}336 \mathrm{~h} \text { (14 days) at } \\
28^{\circ} \mathrm{C}\end{array}$ & $\begin{array}{l}\text { Fermented } \\
\text { lentils flour }\end{array}$ & $\begin{array}{l}\text { Increase in protein } \\
\text { and energy. } \\
\text { Decrease in } \mathrm{CHO} \\
\text { and lipid. }\end{array}$ & $\begin{array}{l}18.5 \% \uparrow \text { in protein, } 15 \% \uparrow \\
\text { in energy, } 8 \% \downarrow \text { in lipid } \\
\text { and } 6 \% \downarrow \text { in CHO. }\end{array}$ & $\begin{array}{l}\mathrm{CHO} \text { decrease due to use as } \\
\text { carbon source. Protein increase } \\
\text { ascribed to bioconversion of } \\
\text { some compounds into protein. }\end{array}$ & $\begin{array}{l}\text { Asensio- } \\
\text { Grau et al. } \\
{[153]}\end{array}$ \\
\hline $\begin{array}{l}\text { Lentils (Lens } \\
\text { culinaris L.) HM-1, } \\
\text { LL-931 and Sapna }\end{array}$ & SSF & $\begin{array}{l}\text { Controlled using } \\
\text { A. awamori (MTCC } \\
\text { 548) }\end{array}$ & $\begin{array}{l}168 \mathrm{~h}(7 \text { days }) \text { at } \\
25^{\circ} \mathrm{C}\end{array}$ & $\begin{array}{l}\text { Aspergillus- } \\
\text { fermented } \\
\text { lentil flour }\end{array}$ & $\begin{array}{l}\text { Increase in minerals } \\
\text { and in vitro } \\
\text { bioavailability of } \\
\text { iron and zinc. }\end{array}$ & $\begin{array}{l}0.07-60 \% \downarrow \text { in minerals, } \\
68.3-90.6 \% \uparrow \text { and } \\
86.7-100.6 \% \uparrow \text { in in vitro } \\
\text { bioavailability of iron } \\
\text { and zinc. }\end{array}$ & $\begin{array}{l}\text { Higher digestibility of iron and } \\
\text { zinc attributed to reduced } \\
\text { presence of ANFs. }\end{array}$ & $\begin{array}{l}\text { Dhull et al. } \\
\text { [185] }\end{array}$ \\
\hline
\end{tabular}


Table 4. Cont.

\begin{tabular}{|c|c|c|c|c|c|c|c|c|}
\hline Raw Material & $\begin{array}{c}\text { Fermentation } \\
\text { Type }\end{array}$ & $\begin{array}{l}\text { Fermentation } \\
\text { Form }\end{array}$ & $\begin{array}{c}\text { Fermentation } \\
\text { Conditions }\end{array}$ & Product & $\begin{array}{c}\text { Modification(s) in } \\
\text { Nutritional } \\
\text { Constituents }\end{array}$ & $\begin{array}{l}\text { Percentage } \\
\text { Difference }\end{array}$ & Key Mechanism(s) Involved & Reference \\
\hline $\begin{array}{l}\text { Lima bean } \\
\text { (Phaseolus lunatus) }\end{array}$ & SmF & Spontaneous & $72 \mathrm{~h}$ at $32^{\circ} \mathrm{C}$ & $\begin{array}{l}\text { Fermented } \\
\text { lima bean } \\
\text { flour }\end{array}$ & $\begin{array}{l}\text { Increase in CHO. } \\
\text { Decrease in crude } \\
\text { protein, fibre, fat } \\
\text { content, ash, } \\
\text { minerals and ANFs. }\end{array}$ & $\begin{array}{l}3 \% \uparrow \text { in } \mathrm{CHO}, 3 \% \downarrow \text { in } \\
\text { protein, } 25 \% \downarrow \text { in fibre, } \\
4 \% \downarrow \text { in fat, } 17 \% \downarrow \text { in ash, } \\
5-13 \% \downarrow \text { in minerals, } \\
78 \% \downarrow \text { in tannin, } 89 \% \downarrow \text { in } \\
\text { PT, } 97 \% \downarrow \text { in TIA, } 75 \% \downarrow \\
\text { in lectin, } 95 \% \downarrow \text { in } \\
\text { oxalate and } 91 \% \downarrow \text { in } \\
\text { cyanide. }\end{array}$ & $\begin{array}{l}\text { Decrease in protein due to } \\
\text { previous heat treatment during } \\
\text { processing. Reduced fat } \\
\text { attributed to loss of total solids } \\
\text { and fat denaturation. Decrease } \\
\text { in minerals contents was due to } \\
\text { leaching and reduced ANFs } \\
\text { ascribed to microbial } \\
\text { degradation. }\end{array}$ & $\begin{array}{l}\text { Farinde } \\
\text { et al. [186] }\end{array}$ \\
\hline $\begin{array}{l}\text { Lupin (Lupinus } \\
\text { albus and Lupinus } \\
\text { luteus) }\end{array}$ & SSF & $\begin{array}{l}\text { Spontaneous and } \\
\text { controlled using } \\
\text { LABs (L. sakei, } \\
\text { Pediococcus } \\
\text { acidilactici and } \\
\text { Pediococcus } \\
\text { pentosaceus) }\end{array}$ & $\begin{array}{l}24 \mathrm{~h} \text { at } 30^{\circ} \mathrm{C} \text { for } \mathrm{L} \text {. } \\
\text { sakei, } 32^{\circ} \mathrm{C} \text { for } \\
\text { Pediococcus } \\
\text { acidilactici and } \\
35^{\circ} \mathrm{C} \text { for } \\
\text { Pediococcus } \\
\text { pentosaceus }\end{array}$ & $\begin{array}{l}\text { Fermented } \\
\text { whole meal }\end{array}$ & Increase in IVPD. & $\begin{array}{l}3.5-17.7 \% \uparrow \text { in IVPD for } \\
\text { Lupinus albus. and } \\
7.8-19 \% \uparrow \text { in IVPD for } \\
\text { Lupinus luteus. }\end{array}$ & Not reported. & $\begin{array}{l}\text { Bartkiene } \\
\text { et al. [187] }\end{array}$ \\
\hline
\end{tabular}


Table 4. Cont.

\begin{tabular}{|c|c|c|c|c|c|c|c|c|}
\hline Raw Material & $\begin{array}{c}\text { Fermentation } \\
\text { Type }\end{array}$ & $\begin{array}{l}\text { Fermentation } \\
\text { Form }\end{array}$ & $\begin{array}{l}\text { Fermentation } \\
\text { Conditions }\end{array}$ & Product & $\begin{array}{c}\text { Modification(s) in } \\
\text { Nutritional } \\
\text { Constituents }\end{array}$ & $\begin{array}{l}\text { Percentage } \\
\text { Difference }\end{array}$ & Key Mechanism(s) Involved & Reference \\
\hline $\begin{array}{l}\text { Lupins (Lupinus } \\
\text { angustifolius L.) }\end{array}$ & SSF & $\begin{array}{l}\text { Controlled using } \\
\text { A. sojae, A. ficuum } \\
\text { and their } \\
\text { co-cultures }\end{array}$ & $\begin{array}{l}168 \mathrm{~h} \text { (7 days) at } \\
30^{\circ} \mathrm{C}\end{array}$ & $\begin{array}{l}\text { Fermented } \\
\text { lupin } \\
\text { flours }\end{array}$ & $\begin{array}{l}\text { Increase in fat, ash, } \\
\text { crude fibre fractions, } \\
\text { protein, starch, } \\
\text { calcium and } \\
\text { phosphorus. } \\
\text { Decrease in IVPD } \\
\text { and PA. A decrease } \\
\text { and increase in } \\
\text { soluble CHO. }\end{array}$ & $\begin{array}{l}53.3-73.2 \% \downarrow \text { in PA, } \\
1.40 \% \downarrow \text { and } 0.64-1.8 \% \uparrow \\
\text { in crude protein, } \\
3-11 \% \uparrow \text { in fat, } 3-7 \% \uparrow \text { in } \\
\text { ash, } 9 \% \downarrow \text { and } 7-10 \% \uparrow \text { in } \\
\text { crude fibre, } 0.3-15.3 \% \uparrow \\
\text { in acid detergent fibre, } \\
11.4-35.2 \% \uparrow \text { in neutral } \\
\text { detergent fibre, } \\
40-87 \% \uparrow \text { in } \\
\text { hemicellulose, } 21-56 \% \uparrow \\
\text { in lignin, } 6 \% \downarrow \text { and } \\
1.8-14 \% \uparrow \text { in cellulose, } \\
7-16.8 \downarrow \text { and } 5.6 \uparrow \text { in } \\
\text { soluble CHO, } 98-700 \% \uparrow \\
\text { in starch, } 16-32.5 \% \downarrow \text { in } \\
\text { IVPD, } 14-29 \% \uparrow \text { in } \\
\text { calcium and } 10-13 \% \uparrow \text { in } \\
\text { phosphorus. }\end{array}$ & $\begin{array}{l}\text { Increase protein attributed to } \\
\text { production of fungal protein. } \\
\text { Reduction in IVPD due to } \\
\text { protein being locked within the } \\
\text { fibre matrix, reducing the } \\
\text { hydrolytic action of enzymes. }\end{array}$ & $\begin{array}{l}\text { Olukomaiya } \\
\text { et al. [150] }\end{array}$ \\
\hline $\begin{array}{l}\text { Lupin (Lupinus } \\
\text { angustifolius L.) } \\
\text { var. 'Vilniai' and } 6 \\
\text { hybrid lines (1700, } \\
\text { 1701, 1703, 1072, } \\
\text { 1734, 1800) }\end{array}$ & SmF and SSF & $\begin{array}{l}\text { Controlled using } \\
\text { L. sakei KTU05-6 }\end{array}$ & $48 \mathrm{~h}$ at $30^{\circ} \mathrm{C}$ & $\begin{array}{l}\text { Fermented } \\
\text { lupin seeds }\end{array}$ & Increase in AAs. & $\begin{array}{l}2.7-1287 \% \uparrow \text { in AAs for } \\
\text { SmF samples and } \\
0.7-613 \% \uparrow \text { in AAs for } \\
\text { SSF samples. }\end{array}$ & Not reported. & $\begin{array}{l}\text { Starkute } \\
\text { et al. [189] }\end{array}$ \\
\hline
\end{tabular}


Table 4. Cont.

\begin{tabular}{|c|c|c|c|c|c|c|c|c|}
\hline Raw Material & $\begin{array}{c}\text { Fermentation } \\
\text { Type }\end{array}$ & $\begin{array}{l}\text { Fermentation } \\
\text { Form }\end{array}$ & $\begin{array}{c}\text { Fermentation } \\
\text { Conditions }\end{array}$ & Product & $\begin{array}{l}\text { Modification(s) in } \\
\text { Nutritional } \\
\text { Constituents }\end{array}$ & $\begin{array}{l}\text { Percentage } \\
\text { Difference }\end{array}$ & Key Mechanism(s) Involved & Reference \\
\hline $\begin{array}{l}\text { Lyon bean } \\
\text { (Mucuna } \\
\text { cochinchinensis) }\end{array}$ & SSF & Spontaneous & $\begin{array}{l}0-72 \mathrm{~h}(24 \mathrm{~h} \\
\text { interval }) \text { at } 30{ }^{\circ} \mathrm{C}\end{array}$ & $\begin{array}{l}\text { Fermented } \\
\text { Lyon bean } \\
\text { flour }\end{array}$ & $\begin{array}{l}\text { Reduction in oxalate, } \\
\text { PA, tannin and } \\
\mathrm{CHO} \text {. Increase in } \\
\text { protein. Increase in } \\
\text { fat and decrease at } \\
72 \mathrm{~h} \text {. Increase in ash } \\
\text { and decrease at } 48 \mathrm{~h} \text {. } \\
\text { Increase in fibre. }\end{array}$ & $\begin{array}{l}1.1-60.1 \% \uparrow \text { and } 0.41 \% \downarrow \\
\text { in protein, } 51.6-111 \% \uparrow \\
\text { in fat, } 7.1-49.9 \% \uparrow \text { and } \\
8.5-13 \% \downarrow \text { in ash, } \\
54.3-179.3 \% \uparrow \text { in fibre, } \\
5.4-25.9 \% \downarrow \text { in CHO, } \\
16.5-68 \% \downarrow \text { in oxalate, } \\
13.7-26 \% \downarrow \text { in PA and } \\
9.2-25.7 \% \downarrow \text { in tannin. }\end{array}$ & Not reported. & $\begin{array}{l}\text { Olaleye } \\
\text { et al. [190] }\end{array}$ \\
\hline $\begin{array}{l}\text { Mahogany Bean } \\
\text { (Afzelia africana) }\end{array}$ & SmF & Spontaneous & $\begin{array}{l}0,24,48,72 \mathrm{~h} \\
\text { at } 30^{\circ} \mathrm{C}\end{array}$ & $\begin{array}{l}\text { Fermented } \\
\text { mahogany } \\
\text { bean flour }\end{array}$ & $\begin{array}{l}\text { Increase in protein, } \\
\text { fat, fibre, ash and } \\
\text { CHO. }\end{array}$ & $\begin{array}{l}3-15 \% \uparrow \text { in protein, } \\
3-39 \% \uparrow \text { in fat, } 2.6-7 \% \uparrow \\
\text { in fibre, } 3-18 \% \downarrow \text { in ash } \\
\text { and } 12-61 \% \downarrow \text { in CHO. }\end{array}$ & $\begin{array}{l}\text { Increased protein attributed to } \\
\text { increase in microbial mass and } \\
\text { extensive protein hydrolysis to } \\
\text { AA and other simple peptides. } \\
\text { Fat increase ascribed to } \\
\text { extensive breakdown of large } \\
\text { fat molecules into simple fatty } \\
\text { acids. Loss in ash due to } \\
\text { leaching of soluble minerals } \\
\text { into the processing water. CHO } \\
\text { reduction attributed to } \\
\text { conversion of oligosaccharides } \\
\text { to simple sugars or utilization } \\
\text { of CHO for growth and } \\
\text { metabolism. }\end{array}$ & $\begin{array}{l}\text { Igbabul } \\
\text { et al. [191] }\end{array}$ \\
\hline $\begin{array}{l}\text { Mung bean } \\
\text { (Vigna radiata) }\end{array}$ & SmF & $\begin{array}{l}\text { Spontaneous and } \\
\text { back-slopping }\end{array}$ & $72 \mathrm{~h}$ at $\mathrm{RT}$ & $\begin{array}{l}\text { Fermented } \\
\text { mung bean } \\
\text { flour }\end{array}$ & $\begin{array}{l}\text { Decrease in fat, } \\
\mathrm{CHO} \text { and vitamin A. } \\
\text { Increase in fibre, in } \\
\text { ash and some } \\
\text { minerals. }\end{array}$ & $\begin{array}{l}\text { Fermented and } \\
\text { back-slopping: } 33 \text { and } \\
38 \% \downarrow \text { in fat; } 60 \% \downarrow \text { in } \\
\text { vitamin A of both, } 50 \\
\text { and } 35 \% \uparrow \text { in fibre, } \\
7.2 \% \downarrow \text { in CHO, } 51.2 \% \downarrow \\
\text { and } 6.3 \% \uparrow \text { in ash and } \\
8.8-22.6 \% \uparrow \text { in calcium } \\
\text { and iron. }\end{array}$ & $\begin{array}{l}\text { Decreased fat due to activities } \\
\text { of lipolytic enzymes. Reduction } \\
\text { in CHOs due to its use as } \\
\text { energy source. }\end{array}$ & $\begin{array}{l}\text { Onwurafor } \\
\text { et al. [192] }\end{array}$ \\
\hline
\end{tabular}


Table 4. Cont.

\begin{tabular}{|c|c|c|c|c|c|c|c|c|}
\hline Raw Material & $\begin{array}{c}\text { Fermentation } \\
\text { Type }\end{array}$ & $\begin{array}{l}\text { Fermentation } \\
\text { Form }\end{array}$ & $\begin{array}{c}\text { Fermentation } \\
\text { Conditions }\end{array}$ & Product & $\begin{array}{l}\text { Modification(s) in } \\
\text { Nutritional } \\
\text { Constituents }\end{array}$ & $\begin{array}{l}\text { Percentage } \\
\text { Difference }\end{array}$ & Key Mechanism(s) Involved & Reference \\
\hline $\begin{array}{l}\text { Pea (Pisum } \\
\text { sativum) }\end{array}$ & SSF & $\begin{array}{l}\text { Controlled using } \\
\text { A. niger NRRL } 334 \\
\text { and A. oryzae } \\
\text { NRRL } 5590\end{array}$ & $\begin{array}{l}0,2,4 \text { and } 6 \mathrm{~h} \\
\text { at } 40^{\circ} \mathrm{C}\end{array}$ & $\begin{array}{l}\text { Fermented } \\
\text { pea } \\
\text { protein- } \\
\text { enriched } \\
\text { flour }\end{array}$ & $\begin{array}{l}\text { Increase in AAs, } \\
\text { protein and IVPD of } \\
\text { the fermented } \\
\text { samples over } \\
\text { fermentation time } \\
\text { but a decrease in } \\
\text { AAs of the } A \text {. niger. } \\
\text { Decrease in ash at } 6 \\
\text { h fermentation for } A \text {. } \\
\text { oryzae and increase } \\
\text { in lipid at } 2 \mathrm{~h} \\
\text { fermentation for } \\
\text { A. niger. }\end{array}$ & $\begin{array}{l}4-32 \% \downarrow \text { in TIA, } \\
0.5-14 \% \uparrow \text { in protein, } \\
0.2-8.7 \% \uparrow \text { and } \\
0.6-0.9 \% \downarrow \text { in ash, } \\
0.6-94 \% \downarrow \text { and } 20 \% \uparrow \text { in } \\
\text { lipid, } \\
0.93 \% \downarrow \text { and } 0.67-8 \% \uparrow \text { in } \\
\text { IVPD and } \\
0.7-10 \% \downarrow \text { and } 1.8-29 \% \uparrow \\
\text { in AAs. }\end{array}$ & $\begin{array}{l}\text { Increase in protein content } \\
\text { attributed to increase in fungal } \\
\text { biomass. Decrease in AAs due } \\
\text { to fungi utilizing the AAs as } \\
\text { food source. }\end{array}$ & $\begin{array}{l}\text { Kumitch } \\
\text { [11]; } \\
\text { Kumitch } \\
\text { et al. [143] }\end{array}$ \\
\hline $\begin{array}{l}\text { Pigeon pea } \\
\text { (Cajanus cajan) }\end{array}$ & SSF & Spontaneous & $\begin{array}{l}168 \mathrm{~h} \text { ( } 7 \text { days at } \\
1 \mathrm{~h} \text { interval }) \text { at } \mathrm{RT}\end{array}$ & $\begin{array}{l}\text { Fermented } \\
\text { pigeon pea } \\
\text { seed flour }\end{array}$ & $\begin{array}{l}\text { Increase in protein } \\
\text { and ash. Decrease in } \\
\text { fat, fibre, nitrogen } \\
\text { free extract and } \\
\text { energy. }\end{array}$ & $\begin{array}{l}3.7-9.6 \% \uparrow \text { in protein, } \\
16-38 \% \downarrow \text { in fat, } \\
6.7-19.7 \% \uparrow \text { in ash, } \\
22.5-37.7 \% \downarrow \text { in fibre, } \\
0.4-4.3 \% \downarrow \text { in } \\
\text { nitrogen-free extract } \\
\text { and } 0.5-3 \% \downarrow \text { in energy. }\end{array}$ & $\begin{array}{l}\text { Increase in protein ascribed to } \\
\text { synthesis of protein and AAs. } \\
\text { Fat reduction due to increased } \\
\text { activities of lipolytic enzymes } \\
\text { causing fat hydrolysis. }\end{array}$ & $\begin{array}{l}\text { Adebowale } \\
\text { and Maliki } \\
{[145]}\end{array}$ \\
\hline $\begin{array}{l}\text { Pigeon pea } \\
\text { (Cajanus cajan) }\end{array}$ & SSF & $\begin{array}{l}\text { Spontaneous and } \\
\text { back-slopping }\end{array}$ & $72 \mathrm{~h}$ at $\mathrm{RT}$ & $\begin{array}{l}\text { Fermented } \\
\text { pigeon } \\
\text { peas flour }\end{array}$ & $\begin{array}{l}\text { Increase and } \\
\text { decrease in ash, fat, } \\
\text { fibre, protein and } \\
\text { CHO. Increase in } \\
\text { energy. }\end{array}$ & $\begin{array}{l}0.2 \% \uparrow \text { and } 17-36.8 \% \downarrow \text { in } \\
\text { ash, } 0.32-8.6 \uparrow \text { and } \\
7-18.6 \% \downarrow \text { in fat, } \\
2.2-6.4 \% \uparrow \text { and } 12-20 \% \downarrow \\
\text { in fibre, } 5-20.8 \% \uparrow \text { and } \\
9.4 \% \downarrow \text { in protein, } \\
3.3-7.8 \% \uparrow \text { and } 1 \% \downarrow \text { in } \\
C H O \text { and } 50.6-57.4 \% \uparrow \\
\text { in energy. }\end{array}$ & $\begin{array}{l}\text { Increase in protein attributed to } \\
\text { activities of extracellular } \\
\text { enzymes. }\end{array}$ & $\begin{array}{l}\text { Odion- } \\
\text { Owase } \\
\text { et al. [193] }\end{array}$ \\
\hline
\end{tabular}


Table 4. Cont.

\begin{tabular}{|c|c|c|c|c|c|c|c|c|}
\hline Raw Material & $\begin{array}{l}\text { Fermentation } \\
\text { Type }\end{array}$ & $\begin{array}{l}\text { Fermentation } \\
\text { Form }\end{array}$ & $\begin{array}{l}\text { Fermentation } \\
\text { Conditions }\end{array}$ & Product & $\begin{array}{l}\text { Modification(s) in } \\
\text { Nutritional } \\
\text { Constituents }\end{array}$ & $\begin{array}{l}\text { Percentage } \\
\text { Difference }\end{array}$ & Key Mechanism(s) Involved & Reference \\
\hline $\begin{array}{l}\text { Red bean } \\
\text { (Phaseolus } \\
\text { angularis (Willd.) } \\
\text { W.F. Wight.) }\end{array}$ & SSF & $\begin{array}{l}\text { Controlled using } \\
\text { Cordyceps militaris }\end{array}$ & $\begin{array}{l}168 \mathrm{~h} \text { (7 days) } \\
\text { at } 25^{\circ} \mathrm{C}\end{array}$ & $\begin{array}{l}\text { Fermented } \\
\text { red bean } \\
\text { flour }\end{array}$ & $\begin{array}{l}\text { Increase in protein, } \\
\text { ash and some AAs. } \\
\text { Decrease in fat and } \\
\text { CHO. }\end{array}$ & $\begin{array}{l}9.3 \% \uparrow \text { in crude protein, } \\
2.7 \% \downarrow \text { in fat, } 5.6 \% \uparrow \text { in } \\
\text { ash, } 3.2 \% \downarrow \text { in } \mathrm{CHO} \text { and } \\
4.8-43.9 \% \downarrow \text { and } \\
7-230 \% \uparrow \text { in AAs. }\end{array}$ & $\begin{array}{l}\text { Reduction in CHO due to its } \\
\text { use as energy source for fungal } \\
\text { growth. Increase in AAs due to } \\
\text { synthesis or transamination. }\end{array}$ & $\begin{array}{l}\text { Xiao et al. } \\
\text { [148] }\end{array}$ \\
\hline $\begin{array}{l}\text { Soybean } \\
\text { (Glycine max) }\end{array}$ & SSF & $\begin{array}{l}\text { Controlled using } \\
\text { L. plantarum Lp6 }\end{array}$ & $72 \mathrm{~h}$ at $37^{\circ} \mathrm{C}$ & $\begin{array}{l}\text { Fermented } \\
\text { soybean } \\
\text { protein } \\
\text { meal and } \\
\text { fermented } \\
\text { soybean } \\
\text { protein } \\
\text { meal with } \\
\text { added } \\
\text { protease }\end{array}$ & $\begin{array}{l}\text { Increase in IVPD } \\
\text { and nitrogen } \\
\text { solubility. }\end{array}$ & $\begin{array}{l}9 \% \uparrow \text { in IVPD and } 4.4 \% \uparrow \\
\text { in nitrogen solubility for } \\
\text { fermented soybean } \\
\text { protein meal; } 12 \% \uparrow \text { in } \\
\text { IVPD and } 2.2 \% \uparrow \text { in } \\
\text { nitrogen solubility for } \\
\text { fermented soybean } \\
\text { protein meal with } \\
\text { added protease. }\end{array}$ & $\begin{array}{l}\text { Increase in IVPD related to } \\
\text { positive influence of protein } \\
\text { degradation by proteases. }\end{array}$ & $\begin{array}{l}\text { Amadou } \\
\text { et al. [194] }\end{array}$ \\
\hline $\begin{array}{l}\text { Soybean (G. max) } \\
\text { Rudoji and } \\
\text { progress varieties }\end{array}$ & SSF & $\begin{array}{l}\text { Spontaneous and } \\
\text { controlled using } \\
\text { LABs (L. sakei, } \\
\text { Pediococcus } \\
\text { acidilactici and } \\
\text { Pediococcus } \\
\text { pentosaceus) }\end{array}$ & $\begin{array}{l}24 \mathrm{~h} \text { at } 30^{\circ} \mathrm{C} \text { for } L \text {. } \\
\text { sakei, } 32^{\circ} \mathrm{C} \text { for } \\
\text { Pediococcus } \\
\text { acidilactici and } \\
35^{\circ} \mathrm{C} \text { for } \\
\text { Pediococcus } \\
\text { pentosaceus }\end{array}$ & $\begin{array}{l}\text { Fermented } \\
\text { whole meal }\end{array}$ & Increase in IVPD. & $\begin{array}{l}9-17 \% \uparrow \text { in IVPD for } \\
\text { Rudoji and } 10-15 \% \uparrow \text { in } \\
\text { IVPD for progress. }\end{array}$ & Not reported. & $\begin{array}{l}\text { Bartkiene } \\
\text { et al. [187] }\end{array}$ \\
\hline Soybean (G. max) & $\mathrm{SmF}$ & $\begin{array}{l}\text { Controlled using } \\
\text { starter organisms } \\
\text { Streptococcus } \\
\text { thermophilus CCRC } \\
14,085 \text { and } \\
\text { Bifidobacterium } \\
\text { infantis CCRC } \\
14,603\end{array}$ & $24 \mathrm{~h}$ at $37^{\circ} \mathrm{C}$ & $\begin{array}{l}\text { Fermented } \\
\text { soymilk }\end{array}$ & $\begin{array}{l}\text { Decrease in saponin } \\
\text { and PA. }\end{array}$ & $\begin{array}{l}46.9 \% \downarrow \text { in saponin and } \\
28.9 \% \downarrow \text { in PA. }\end{array}$ & $\begin{array}{l}\text { Reduction in PA due to phytase } \\
\text { and } \beta \text {-glucosidase activities. }\end{array}$ & $\begin{array}{l}\text { Lai et al. } \\
\text { [195] }\end{array}$ \\
\hline
\end{tabular}


Table 4. Cont.

\begin{tabular}{|c|c|c|c|c|c|c|c|c|}
\hline Raw Material & $\begin{array}{c}\text { Fermentation } \\
\text { Type }\end{array}$ & $\begin{array}{l}\text { Fermentation } \\
\text { Form }\end{array}$ & $\begin{array}{c}\text { Fermentation } \\
\text { Conditions }\end{array}$ & Product & $\begin{array}{c}\text { Modification(s) in } \\
\text { Nutritional } \\
\text { Constituents }\end{array}$ & $\begin{array}{l}\text { Percentage } \\
\text { Difference }\end{array}$ & Key Mechanism(s) Involved & Reference \\
\hline Soybean (G. max) & $\mathrm{SmF}$ & Spontaneous & $\mathrm{Up}$ to $72 \mathrm{~h}$ at RT & $\begin{array}{l}\text { Fermented } \\
\text { soymilk }\end{array}$ & $\begin{array}{l}\text { Decrease in } \mathrm{CHO} \\
\text { and fat. Increase in } \\
\text { ash, protein and } \\
\text { minerals. Decrease } \\
\text { in energy value but } \\
\text { an increase at } 6 \text { and } \\
12 \mathrm{~h} \text { fermentation. }\end{array}$ & $\begin{array}{l}10-99 \% \downarrow \text { in } \mathrm{CHO}, \\
8.9-222 \% \uparrow \text { in ash, } \\
2.2-53 \% \uparrow \text { in minerals, } \\
5-94 \% \uparrow \text { in protein, } \\
2.3-60 \% \downarrow \text { in fat and } \\
7.5-15.5 \% \downarrow \text { and } \\
0.1-7.4 \% \uparrow \text { in energy } \\
\text { value. }\end{array}$ & $\begin{array}{l}\text { Reduction in CHO due to its } \\
\text { use as energy source. Release of } \\
\text { minerals from chelated } \\
\text { complexes, influenced its } \\
\text { increase. Protein increase due } \\
\text { to anabolic processes causing } \\
\text { build-up of protein-related } \\
\text { polymers and microbial cell } \\
\text { proliferation. Decrease in fat } \\
\text { connected to increased } \\
\text { activities of the lipolytic } \\
\text { enzymes which caused fat } \\
\text { hydrolysis. }\end{array}$ & $\begin{array}{l}\text { Obadina } \\
\text { et al. [151] }\end{array}$ \\
\hline $\begin{array}{l}\text { Soybean }(G . \text { max }) \\
\text { curd waste or } \\
\text { okara }\end{array}$ & SSF & $\begin{array}{l}\text { Controlled using } \\
\text { Candida albicans } \\
\text { NRRL Y-12, C. } \\
\text { guilliermondii } \\
\text { NRRL Y-2075, } \\
\text { Kluyveromyces } \\
\text { marxianus NRRL } \\
\text { Y-7571, } \\
\text { Kluyveromyces } \\
\text { marxianus NRRL } \\
\text { Y-8281, Pichia } \\
\text { pinus and S. } \\
\text { cerevisiae NRRL } \\
\text { Y-12632 }\end{array}$ & $72 \mathrm{~h}$ at $30^{\circ} \mathrm{C}$ & $\begin{array}{l}\text { Fermented } \\
\text { okara }\end{array}$ & $\begin{array}{l}\text { Decrease in fibre, fat } \\
\text { and CHO. Increase } \\
\text { in protein and ash. }\end{array}$ & $\begin{array}{l}7.4-45.5 \% \downarrow \text { in fibre, } \\
20.1-54.4 \% \uparrow \text { in protein, } \\
2.8-27.8 \% \uparrow \text { in ash, } \\
3.3-29.2 \% \downarrow \text { in fat and } \\
0.71-51.1 \% \downarrow \text { in CHO. }\end{array}$ & $\begin{array}{l}\text { Decrease in fibre linked to } \\
\text { secretion of } \\
\text { cellulose/hemicellulose- } \\
\text { degrading enzymes by } \\
\text { yeasts. }\end{array}$ & $\begin{array}{l}\text { Rashad } \\
\text { et al. [196] }\end{array}$ \\
\hline
\end{tabular}


Table 4. Cont.

\begin{tabular}{|c|c|c|c|c|c|c|c|c|}
\hline Raw Material & $\begin{array}{c}\text { Fermentation } \\
\text { Type }\end{array}$ & $\begin{array}{l}\text { Fermentation } \\
\text { Form }\end{array}$ & $\begin{array}{c}\text { Fermentation } \\
\text { Conditions }\end{array}$ & Product & $\begin{array}{c}\text { Modification(s) in } \\
\text { Nutritional } \\
\text { Constituents }\end{array}$ & $\begin{array}{l}\text { Percentage } \\
\text { Difference }\end{array}$ & Key Mechanism(s) Involved & Reference \\
\hline $\begin{array}{l}\text { Tamarind } \\
\text { (Tamarindus indica } \\
\text { L.) }\end{array}$ & SSF & Spontaneous & $\begin{array}{l}24,48 \text { and } 72 \mathrm{~h} \text { at } \\
\mathrm{RT}\end{array}$ & $\begin{array}{l}\text { daddawa- } \\
\text { type } \\
\text { condiment }\end{array}$ & $\begin{array}{l}\text { Initial increase in } \\
\text { CHO and ANFs } \\
\text { (phytate, trypsin } \\
\text { inhibitor and tannin) } \\
\text { and decrease } \\
\text { afterwards. } \\
\text { Initial decrease in } \\
\text { protein, fat, ash, } \\
\text { fibre and minerals } \\
\text { and subsequent } \\
\text { increase afterwards. }\end{array}$ & $\begin{array}{l}1.04-42 \% \downarrow \text { in CHO, } \\
6-49 \% \downarrow \text { in PT, } \\
0.66-86 \% \downarrow \text { in TI, } \\
25-75 \% \downarrow \text { in tannin, } \\
1-3 \% \uparrow \text { in protein, } \\
3-34 \% \uparrow \text { in fat, } 5-18 \% \uparrow \\
\text { in ash, } 2-41 \% \uparrow \text { in fibre } \\
\text { and } 4-33 \% \uparrow \text { and } \\
1-17 \% \downarrow \text { in minerals. }\end{array}$ & $\begin{array}{l}\text { Decrease in ANFs attributed to } \\
\text { enzymatic activity during } \\
\text { fermentation. The slight } \\
\text { increase in protein due to } \\
\text { synthesis of enzymes and } \\
\text { degradation of protein-related } \\
\text { substrates. }\end{array}$ & $\begin{array}{l}\text { Olagunju } \\
\text { et al. [197] }\end{array}$ \\
\hline $\begin{array}{l}\text { Tamarind } \\
\text { (Tamarindus indica } \\
\text { L.) }\end{array}$ & SSF & Spontaneous & $96 \mathrm{~h}$ (4 days) at $\mathrm{RT}$ & $\begin{array}{l}\text { Tamarind } \\
\text { seed flours }\end{array}$ & $\begin{array}{l}\text { Reduction in ash, } \\
\text { phytate, tannin, TIA } \\
\text { and CHO. Increase } \\
\text { in protein, fat and } \\
\text { fibre }\end{array}$ & $\begin{array}{l}2.3 \% \downarrow \text { in ash, 37-99\% } \downarrow \\
\text { in CHO, } 4.8-14.3 \% \downarrow \text { in } \\
\text { phytate, } 42.9-85.7 \% \downarrow \text { in } \\
\text { tannin, } 78.7-89.4 \% \downarrow \text { in } \\
\text { TIA, } 9.5-24.6 \% \uparrow \text { in } \\
\text { protein, } 17-48.9 \% \uparrow \text { in fat } \\
\text { and } 15-16.7 \% \uparrow \text { in fibre. }\end{array}$ & $\begin{array}{l}\text { Decrease in TIA and phytate } \\
\text { due to enzymatic activities. } \\
\text { Protein increased attributed to } \\
\text { enzyme synthesis and } \\
\text { compositional change } \\
\text { following degradation of other } \\
\text { constituents. Fat increase due } \\
\text { to increased activity of lipolytic } \\
\text { enzymes that led to production } \\
\text { of more fatty-related } \\
\text { compounds. CHO reduction } \\
\text { linked to their use as carbon } \\
\text { source (substrate) in order to } \\
\text { synthesize cell biomass. }\end{array}$ & $\begin{array}{l}\text { Oluseyi } \\
\text { and } \\
\text { Temitayo } \\
\text { [198] }\end{array}$ \\
\hline
\end{tabular}


Table 4. Cont.

\begin{tabular}{|c|c|c|c|c|c|c|c|c|}
\hline Raw Material & $\begin{array}{c}\text { Fermentation } \\
\text { Type }\end{array}$ & $\begin{array}{l}\text { Fermentation } \\
\text { Form }\end{array}$ & $\begin{array}{c}\text { Fermentation } \\
\text { Conditions }\end{array}$ & Product & $\begin{array}{c}\text { Modification(s) in } \\
\text { Nutritional } \\
\text { Constituents }\end{array}$ & $\begin{array}{l}\text { Percentage } \\
\text { Difference }\end{array}$ & Key Mechanism(s) Involved & Reference \\
\hline $\begin{array}{l}\text { Wild Vigna species } \\
\text { of legume } \\
(\text { V. racemosa) }\end{array}$ & SSF & $\begin{array}{l}\text { Spontaneous and } \\
\text { controlled using } \\
\text { A. niger }\end{array}$ & $48 \mathrm{~h}$ at $\mathrm{RT}$ & $\begin{array}{l}\text { Fermented } \\
V \text {. racemosa } \\
\text { flour }\end{array}$ & $\begin{array}{l}\text { Increase in protein } \\
\text { for spontaneous } \\
\text { sample and decrease } \\
\text { in the controlled } \\
\text { fermentation. } \\
\text { Decrease in lipid, } \\
\text { ash, fibre, CHO, } \\
\text { ANFs, minerals, } \\
\text { raffinose and } \\
\text { stachyose, except for } \\
\text { an increase in CHO } \\
\text { of the controlled } \\
\text { fermented sample. }\end{array}$ & $\begin{array}{l}12.4 \% \uparrow \text { in protein, } 9.7 \% \downarrow \\
\text { in lipid, } 12.3 \% \downarrow \text { in ash, } \\
18.4 \% \downarrow \text { in fibre, } 1.02 \% \downarrow \\
\text { in CHO, } 2.6-59 \% \downarrow \text { in } \\
\text { ANFs, } 12.5-98 \% \downarrow \text { in } \\
\text { minerals, } 33 \% \downarrow \text { in } \\
\text { raffinose and } 65 \% \downarrow \text { in } \\
\text { stachyose for the } \\
\text { spontaneous fermented } \\
\text { sample; } 29.4 \% \downarrow \text { in } \\
\text { protein, } 62.8 \% \downarrow \text { in lipid, } \\
31 \% \downarrow \text { in ash, } 0.7 \% \downarrow \text { in } \\
\text { fibre, } 22.9 \% \uparrow \text { in CHO, } \\
30-99 \% \downarrow \text { in ANFs, } \\
42.6-98.2 \% \downarrow \text { in minerals, } \\
59.5 \% \downarrow \text { in raffinose and } \\
87.7 \% \downarrow \text { in stachyose for } \\
\text { controlled fermented } \\
\text { sample. }\end{array}$ & $\begin{array}{l}\text { Increase in protein due to } \\
\text { increase in biomass brought } \\
\text { about by the fermenting } \\
\text { microorganisms. Protein } \\
\text { decrease attributed to } \\
\text { metabolism of } A \text {. niger. } \\
\text { Decrease in ash, fibre, lipid and } \\
\text { CHO due to their metabolism } \\
\text { by the microorganisms. } \\
\text { Reduction in ANFs attributed } \\
\text { to degradation by } \\
\text { microorganisms. Decrease in } \\
\text { mineral contents ascribed to } \\
\text { leaching of the minerals into } \\
\text { fermentation water and mineral } \\
\text { utilization by fermenting } \\
\text { microbiota. Raffinose and } \\
\text { stachyose reduction could be } \\
\text { due to their utilization as } \\
\text { energy sources. }\end{array}$ & $\begin{array}{l}\text { Difo et al. } \\
\text { [199] }\end{array}$ \\
\hline
\end{tabular}

$\downarrow$-decrease; $\uparrow$ —increase; ANFs—antinutritional factors; $\mathrm{CHO}$ - carbohydrate; HCN—hydrogen cyanide; IVPD—in vitro protein digestibility; IVSD—in vitro starch digestibility; PA—phytic acid; PP—phytin phosphorus; PT—phytate; RT—room temperature; SSF—solid-state fermentation; SmF—submerged fermentation; TA—tannic acid; TI—trypsin inhibitor; TIA-trypsin inhibitor activity. 
In legumes, fermentation has been observed to lead to both a decrease and increase in carbohydrate or starch contents (Table 3). A previous study on the determination of available starch contents of two fermented Vigna sinensis seed varieties revealed a reduction in the starch content from $24.3 \%$ to $22.33 \%$ in the orutico variety and from $29.7 \%$ to $22.9 \%$ in the tuy variety, [180] with the authors attributing this to the degradation of available starch by microbial and enzymatic activities. This trend was also reported by Doblado et al. [179] evident with the reduction in total starch, though with a corresponding increase in sugar contents of fermented Vigna sinensis (var carrila) samples. In contrast, an $8 \%$ increase in the starch content and a corresponding $0.5 \%$ decrease in the carbohydrate content was reported in fermented bean powder (using L. fermentum) [152]. Olagunju et al. [197] also reported a reduction in carbohydrate contents of tamarind seeds fermented for 3 days, with values of $1.04-42 \%$. The study related this decrease in carbohydrate content to the decrease in the carbohydrate ratio in the total mass, resulting in the redistribution of nutrient percentages [197]. A 3\% decrease in the carbohydrate content reported during the fermentation of red bean (Phaseolus angularis) was attributed to the use of carbohydrate as the energy source for fungal growth [148]. Different authors [130,144,146,149,153,178,190,191] have all equally reported reductions in carbohydrate levels during the fermentation of African oil bean $(7 \%)$, tempeh $(0.7 \%)$, cowpea (3\%), mahogany bean (up to 61\%), kidney bean (17\%), lentil (6\%), African yam bean (4\%) and Lyon bean (up to $26 \%$ ), and ascribing such reductions to the use of carbohydrate-related compounds as the energy source by fermenting microorganisms for growth and metabolism as well as the conversion of oligosaccharides to simple sugars. The observed varying decreases in the carbohydrate values of these legumes could be due to differences in the inherent composition (e.g., amylose, amylopectin and the structural composition of carbohydrates), plant varieties, species as well as fermenting microorganisms present during the fermentation process. Furthermore, Obadina et al. [151] reported a progressive reduction in carbohydrate contents (10-99\%) of fermented soymilk at $72 \mathrm{~h}$ as the fermentation time increased, attributing this to the activities of the fermenting microorganisms which transformed and utilized them into energy for growth and other cellular activities. According to Olagunju et al. [197], protein fermentation is mostly facilitated by Bacillus spp., and these organisms are notable producers of enzymes such as amylase, glucosidase, fructofuranosidase and lactanase, which could break down different components of carbohydrates in fermenting legumes, leading to their reduction.

Increases in carbohydrate levels of fermented cowpea (up to 5\%) [181], fermented Bambara groundnut (0.3\%) [175], fermented black bean (146\%) [130], fermented lima bean (3\%) [186] and fermented pigeon pea (up to 8\%) [193] were reported with such trends linked to activities of enzymes during fermentation that must have led to the conversion of resistant starches to available starches; subsequently, increasing the carbohydrate contents. Different studies have reported increases and decreases in the energy content during the fermentation of legumes (Table 4). An increase in the energy content of fermented pigeon pea flour (50.6-57.4\%) [193] and fermented lentil flour (15\%) [154] has been previously reported. Decreases in energy contents of fermented African oil bean flour (26\%) [144] and fermented pigeon pea flour (0.5-3\%) [145] have also been observed (Table 4). Obadina et al. [151] recorded both an increase (0.1-7.4\%) as well as a decrease of $7.5-15.5 \%$ in energy value in fermented soymilk. While most of these aforementioned studies did not describe the mechanisms of such modifications in energy values, Adebowale and Maliki [145] linked the decrease in the energy value of fermented pigeon pea flour to the decrease in both the nitrogen-free extract and fat values of the samples.

\subsection{Fats and Fatty Acids}

Most studies on fermented cereal, such as pearl millet and maize-based products $[128,156,157]$, reported a reduction $(6-34 \%)$ in the fat content. The decrease in the fat content has been associated with the metabolism of lipids by the fermenting organisms and the leaching of soluble inorganic salts. In the study conducted by Ejigui et al. [138], a decrease of $11 \%$ in the fat content of fermented maize at $30{ }^{\circ} \mathrm{C}$ for a period of 4 days 
was attributed to a variety of grains, fermentation conditions and steps, such as washing and sieving, which was involved in the production of dough. In addition, Nnam and Obiakor [137] reported about an $81 \%$ reduction in rice fermented for $72 \mathrm{~h}$, whereas in another study on fermented stale rice, Zhang et al. [171] reported an increase (252\%) in the fat content. Nnam and Obiakor [137] attributed the reduction in the fat content of fermented rice to an increase in the lipase activity in the fermenting medium. A decrease in the lipid of $6.1-49 \%$ was reported in rice bran fermented for $120 \mathrm{~h}$ at $30{ }^{\circ} \mathrm{C}$, and this was presumably due to the use of fat-related components for mycelial synthesis [162].

Additionally, in Table 3, most of the studies on the fermentation of legumes, such as African oil bean, African yam beans, black beans, cowpea, kidney beans and lima beans, revealed that fermentation reduced the fat content between $0.63 \%$ and $58.7 \%[130,144,146,149,178,184,186]$. Some of the authors attributed these reductions to the metabolism of microorganisms in the fermentation medium, the breakdown of lipids by lipase, the use of lipids as the food source by fermenting organisms, the loss of total solids during soaking and the denaturation of the fat by heat processing as well as the leaching of fat-related components into the processing water. Onwurafor et al. [192] also reported that fermenting mung bean flour using spontaneous and back-slopping methods for $72 \mathrm{~h}$ reduced the fat content by $33-38 \%$, and this was due to the activities of lipolytic enzymes during fermentation. A similar mechanism for the decrease in fat contents was reported by Adebowale and Maliki [145] in fermented pigeon peas and fermented soybeans [151], and was also attributed to increased activities of the lipolytic enzymes during fermentation, which hydrolysed fat components into fatty acid and glycerol. In contrast, increases in fat levels of fermented chickpea (1.8\%) [147], fermented lupin (3-11\%) [150], fermented African yam bean (86\%) [174], fermented Bambara groundnut (2\%) [175], fermented cowpea (100-133\%) [181], fermented mahogany bean (3-39\%), [191] and fermented tamarind (17-48.9\%) [198] have been reported (Table 4). The mechanisms involved in the increase in the fat content might be linked to the increased activity of lipolytic enzymes that may have produced more fatty acids during the fermentation, the extensive breakdown of large molecules of fat into simple fatty acids, the fat from dead microflora and/or the assumption that fermenting microflora did not use the fat as a source of energy $[174,191,198]$. In their study, Barampama and Simard [152] reported that fermentation reduced fatty acids (linoleic and linolenic fatty acids) in common bean by about $20 \%$. A decrease of $2-18 \%$ and an increase of $2-24 \%$ were also observed in fatty acids of $u g b a$ (fermented African oil bean), and the concentrations of some fatty acids did not change during fermentation. An observed increase as well as a decrease in these fat-related constituents after fermentation suggest selective lipase activities. While these lipolytic enzymes could have contributed to the lipid dissociation and increased the extractability of fat-related constituents, same enzymes could also have selective reductive activities, perhaps using these fat-related components as carbon sources [70,202,203]. Equally important and not highlighted in these studies are the role of other microorganisms involved in fermentation that could have promoted lipid hydrolysis [204,205].

\subsection{Ash and Mineral Composition}

Varying effects of fermentation on the ash and mineral contents of cereals and legumebased food products have been reported, and these effects are independent of the forms of these foods. For fermented pearl millet, Adebiyi et al. [128] reported a decrease in total ash contents from $1.86 \%$ to $1.36 \%$ after fermentation for 3 days; however, they reported an increase in mineral elements such as $\mathrm{Ca}, \mathrm{Na}, \mathrm{Cu}, \mathrm{Fe}, \mathrm{Zn}$ and $\mathrm{K}$. A reduction in ash was attributed to the leaching of soluble salts, while an increase in mineral elements was due to the improved extractability and availability of minerals as a result of fermentation. The study of Nnam and Obiakor [137] reported a reduction in the ash content of rice from 1.5\% at $0 \mathrm{~h}$ of fermentation to $1 \%$ after $72 \mathrm{~h}$, with irregular trends in the values of minerals such as $\mathrm{Ca}, \mathrm{P}, \mathrm{K}, \mathrm{Fe}, \mathrm{Zn}$ and $\mathrm{Cu}$ during time intervals. They attributed the loss in the ash content to a reduction in the dry matter, which was as a result of the breakdown of total solids 
during fermentation. A decrease (14-97.9\%) and increase (3.8-100\%) in minerals were also reported during the fermentation of rice [137]. Both opposing trends were linked to the metabolic activities of the fermenting microorganisms which hydrolyse the metal-phytate complexes to release free minerals for use and losses in dry matter, which led to apparent increases in minerals [137]. An increase of $0.5-14 \%$ in ash with a decrease of $0.5-31 \%$ were also reported during the fermentation of rice, and were attributed to the activation of phytase which reduces phytic acid [134]. The increase in mineral (13-34\%) and ash contents (7\%) of fermented rice was reported by Ilowefah et al. [133], and the increase in the ash content was due to the increase in the mineral solubility and bioavailability. In a similar study by the authors, an increase in mineral (13-34\%) and ash contents (9\%) of fermented rice at $6 \mathrm{~h}$ for $32{ }^{\circ} \mathrm{C}$ was reported as well as an increase in minerals linked to the reduction in phytic acid contents, which may have formed complexes with the minerals [161].

For legumes, an increase in ash contents (Table 4) was reported for fermented soymilk [151], mung beans flour [192] and tamarind seeds [197]. These products were subjected to different fermentation times and recorded a general progressive increase in ash contents as the fermentation time increased, except for the slight reduction in ash content from 0 to $24 \mathrm{~h}$ in fermented tamarind seeds [197]. With an increase in ash contents as the fermentation time increased, a corresponding increase in minerals, such as $\mathrm{Ca}, \mathrm{Mg}, \mathrm{P}, \mathrm{Zn}, \mathrm{Cu}, \mathrm{Mn}$ and $\mathrm{Fe}$, was also reported [197]. This was also similar to the findings of Obadina et al. [151] and Onwurafor et al. [192], who reported increases in $\mathrm{Ca}, \mathrm{Fe}, \mathrm{Mg}$ and $\mathrm{Zn}$ contents as the fermentation progressed. An increase in ash and mineral contents in these studies was ascribed to metabolic activities of microorganisms as well as the breakdown of complex chelated compounds within the fermenting lot, leading to an improved synthesis of minerals. On the other hand, Granito et al. $[180,184]$ reported a significant decrease in ash and mineral contents during the natural and submerged fermentation of Phaseolus vulgaris and two varieties of Vigna sinensis, respectively. They attributed this decrease to the leaching of mineral elements into discarded fermentation water and the utilization of mineral elements for the proper growth of microorganisms during fermentation. The decrease $(29.8 \%)$ in ash content in African yam bean fermented at $24 \mathrm{~h}$ was attributed to vegetative loss, leaching into the fermentation medium as well as the microflora which might have used the ash-related components for metabolism [174]. A decrease (12.1-66.7\%) in some minerals present in fermented Bambara groundnut was attributed to their utilization by fermenting microorganisms for their physiological and metabolic activities, while an increase (2.3-43.8\%) was linked to the reduction in phytic acids and other antinutritional factors [142].

\subsection{Vitamins}

Fermentation has been reported to exhibit varying effects on different vitamins such as $B$ vitamins and vitamin $E$ in cereals and legumes (Tables 3 and 4). In most of the studies, especially in the fermentation of maize, buckwheat, rice and sorghum using different starter cultures (LAB species, yeast and fungi), an increase in vitamin B1, B2, B3 and E were reported by up to 10 folds $[133,157,167,171]$. Ilowefah et al. [134] reported that vitamin B increased in fermented maize flour due to enzyme interactions with starch, protein and other key biosynthetic precursors, which stimulated their synthesis of bound forms of the vitamins. Contrary to these studies, Ejigui et al. [138] and Tamene et al. [172], on the fermentation of maize and tef, reported a reduction in vitamin B1, B2, $\beta$-carotene (as retinol equivalent) and the folate content of the resulting flour and their products. A decrease in vitamins was caused as a result of mechanical loss due to processes, fermentation and lipid solubilization, as well as consumption by other microorganisms or losses due to discarding the supernatant $[138,172]$. In some other studies, fermentation reportedly increased the vitamin B1, B2 and E ( $\alpha$-tocopherols) levels of fermented legumes (cowpea and kidney beans) by 17 to $94 \%[179,184]$. Likewise, levels of vitamin A, B1, B2, B3, $\alpha-, \gamma$ - and $\delta$ tocopherols reportedly reduced in fermented common bean, cowpea, lupin and mung bean by $5-106 \%[152,179,188,192]$. The level of vitamins after fermentation seemed to be 
dependent on the fermenting strain and metabolic activity of these strains. This could have impacted the varying reported trends in the vitamin content.

\subsection{Fibre}

Studies on rice showed that fermentation increased the fibre content in their resulting flours [171] and, likewise, the insoluble and soluble fibre fractions at $22^{\circ} \mathrm{C}$ for $72 \mathrm{~h}$ [133]. The increase in fibre in stale rice by Cordyceps sinensis was attributed to the transformation mechanisms of corresponding substances in the fermentation process, and some mycelia of Cordyceps sinensis possibly attached onto the surface of rice grain [171]. Jood et al. [167] reported about a 10\% reduction in the total and insoluble dietary fibre, and the authors suggested that an increase in the activity of hydrolysing enzymes such as cellulase, $\alpha$-galactosidase, etc., caused the rapid hydrolysis of the insoluble dietary fibre constituents, leading to their conversion into soluble dietary fibres. The mechanism of the decrease in fibre in fermented cereal was attributed to the partial solubilization of cellulose and hemicellulose type of materials by microbial enzymes [30]. Other authors ascribed the reduction in fibre of fermented maize flour $(74 \%)$ to an enzymatic breakdown by LAB, which utilized the fibre as a carbon source [156]. In addition, the authors explained that due to the enhanced activity of $\beta$-glucanases and carboxypeptidases, insoluble $\beta$-glucan could be degraded into soluble $\beta$-glucan and, further, due to the fermentation activity of other enzymes such as $\beta$-glucosidases, cellobiose, etc., it could hydrolyse the soluble $\beta$-glucan into glucose. A 55\% decrease in fibre was attributed to the enzymatic degradation of the fibre during the fermentation process of fermented pearl millet [158], while a decrease of $40 \%$ in fibre levels in fermented sorghum was attributed to the partial solubilisation of cellulose and hemicellulosic type of material by microbial enzymes [132]. Onyimba et al. [135] reported a decrease of 66-69\% in fermented sorghum and ascribed this to the action of cellulolytic microorganisms present in the fermenting substrate [135]. Likewise, a $22 \%$ decrease in fermented oats was ascribed to the action of enzymes from Pleurotus ostreatus such as hemicellulase, xylanases, cellulase and laccase [130].

The fermentation of various legume seeds and their effect on fibre levels have also been reported (Table 3). In legume seeds, such as African yam beans and Lima beans, fermentation reduced the crude fibre content, with other studies equally reporting that fermentation reduced the insoluble and soluble fibres of pigeon pea and kidney beans $[149,174,184,186]$. The decrease in crude fibre was attributed to hydrolysis and leaching into the fermentation medium, or the microflora used the fibre-related components for its metabolism [174], while a decrease in insoluble fibre was ascribed to the use of cellulose and arabinoxilnase by the fermenting microorganisms [184]. The decrease in the fibre content $(59 \%)$ in black bean fermented at $336 \mathrm{~h}$ (14 days) with the Pleurotus ostreatus CS155 strain was attributed to the action of enzymes from Pleurotus ostreatus, such as hemicellulase, xylanases, cellulase and laccase [130]. Additionally, a study on curd waste from soybeans fermented with two types of yeasts showed that a decrease in fibre (7.4-46\%) was an indication of the secretion of cellulose/hemicellulose-degrading enzymes by the yeasts during fermentation, and the individual preparation of yeast may have different enzyme activities as well as being able to interact differently with soluble and insoluble fibre components [196]. In common beans and lupin seeds, Barampama and Simard [152] and Olukomaiya et al. [150] reported that due to microbial actions, the acid detergent fibre increased about $86 \%$, and others, such as hemicellulose and lignin and cellulose, were approximately $2-14 \%$ of the fibre fractions. The increase in cellulose was ascribed to the build-up of acid, alkaline or neutral detergent-insoluble substances causing the fibre values to be overestimated [150].

\subsection{Antinutritional Factors}

Food fermentation has been shown to effectively increase the nutritional composition of foods as well as decrease the levels of antinutritional factors (ANFs) and toxic constituents, and might be a better alternative in minimizing the adverse effects of these compounds in diets $[197,206]$. The fermentation of sorghum flour reduced hydrogen cyanide by 
$52.3 \%$ [168], while Nivetha et al. [154] reported a 66\% reduction in the cyanogenic glycosides content of a linseed (Linum usitatissimum) fermented beverage using Lactobacillus acidophilus [154]. The reduction in cyanogenic glycosides was due to the breakdown and degradation of the ANFs into smaller units by the action of the enzymes mobilized during the fermentation period [154]. The inherent phytase activity of sorghum activated by LAB during fermentation degraded phytates, while the decrease in tannin content was due to microbial activity and phytate acyl hydrolases [168]. Likewise, decreases between 30\% and $98.7 \%$ in tannin levels were reported in ting (a fermented product from sorghum), and were attributed to the rearrangement and depolymerization of the tannin structure [163-165]. This can be linked to the acidic environment of the fermentation medium, reduced extractability, selfpolymerization, interaction of tannin with other macromolecules (such as starch and AAs) and the ability of LABs to possibly metabolize tannins [163-165]. Indications from these studies suggest that fermentation leads to the production of enzymes, such as tannase [130], that reduce and/or eliminate tannins during this process. In fermented rice, the decrease in tannin (50\%) was attributed to milling, which removed most of the tannin-related fractions, while phytate (19-69\%) was reduced due to the increased activities of phytases during fermentation [137], and the reduction in ANFs in sorghum fermented for $72 \mathrm{~h}$ at room temperature was due to the ability of microorganisms to use them up [169].

For legumes, the decrease in ANFs of fermented African oil bean (24-79\%) was attributed to soaking (which caused some of the ANFs to leach out), as well as microflora enzymes which degraded organic complexes to release antinutrients and the subsequent leach out of these components into the surrounding medium [173]. Adebiyi et al. [142] observed significant reductions in ANFs in unhulled dawadawa samples from Bambara groundnut - phytic acid (18.06\%), oxalate (59.12\%) and tannin $(34.16 \%)$ - with the reduction in phytic acid attributed to the enzymatic activity of fermenting microorganisms that degrade phytic acid or the complex(es) formed by them. In fermented Bambara groundnut flour, a decrease of $16-42 \%$ in ANFs was also observed, and this was due to the effect of the biodegradation of chemicals involved during fermentation [175]. Similarly, the traditional fermentation of tamarind seed for the production of iru (daddawa) resulted in a significant reduction in ANFs, tannin contents (75\%), phytic acid contents (50\%) and trypsin inhibitor activity (86\%), while Bacillus pumilus, B. subtilis and B. licheniformis were implicated as the organisms responsible for fermenting the legume [89]. A 29\% decrease in phytic acid in fermented soymilk was ascribed to the action of phytase and $\beta$-glucosidase produced by fermenting microbes [197]. Olaleye et al. [190] reported an increased nutritional content as well as a significant reduction in oxalate (16.5-68\%), phytate (13.7-26\%) and tannin (9.2-25.7\%), following the fermentation of beans for $72 \mathrm{~h}$ at $45^{\circ} \mathrm{C}$ with no reported mechanism. As described in various studies, the fermentation of cereals and legumes reduces tannins via hydrolysis by tannase, which catalyses the hydrolysis of ester and depside bonds, yielding gallic acid and glucose $[168,207,208]$. This enzymic degradation of tannins is facilitated by a lower $\mathrm{pH}$, such as that achieved during the fermentation of legumes and cereals. Some researchers have suggested that the reduction in tannins during fermentation may also be attributed to its water solubility; hence, leaching out into the fermenting media, just as all other polyphenolic compounds [207-209]. Elsewhere, the fermentation of tamarind seed for $72 \mathrm{~h}$ resulted in up to an $85.7 \%$ reduction in tannin, $89.4 \%$ reduction in trypsin inhibitor activity and $14.3 \%$ reduction in phytate [198]. The decrease in phytate was attributed to a wide range of microflora that is known to possess phytase activity and enzymatic hydrolysis that causes a decrease in trypsin inhibitor activity [198]. Some authors argue that phytate reduction during fermentation is a consequence of plant phytases activated during fermentation, although phytase activity is very variable depending on the plant species [210-212]. According to Licandro et al. [212], fermentation leads to the production of organic acids, decreasing the $\mathrm{pH}$ of the substrate and, thus, optimizing conditions for the activity of phytases.

A number of studies have reported reductions in oxalate concentrations after fermentation-27\% in dawadawa [142], 62-77\% in ugba [173], 36-52\% in fermented Bambara 
groundnut flour [176], 67\% in fermented horse gram flour [183] and 95\% in fermented lima bean [186], with such reductions attributed to the utilization of oxalate as a carbon source of microbes and the microbial degradation of ANF-related components [183,186]. It has also been suggested that the reduction in oxalate content following fermentation can be attributed to the hydrolytic action of enzymes produced during fermentation [213].

\subsection{Nutrient Digestibility and Bioavailability}

Fermentation is known to enhance nutrient bioaccessibility, bioavailability and digestibility, mainly via the disruption of plant cell wall structures/tissues and the release of enzymes and other bioactive components. Additionally, lower $\mathrm{pH}$ values of the food medium attained during fermentation may improve the absorption of certain nutrients, as well as facilitate the decrease in some ANFs which interfere with nutrient bioavailability and bioaccessibility. The quality of protein should not only consider the composition of AAs, but also the digestibility as well as the absorption of the produced hydrolysis products in the human gastrointestinal tract [214-216]. For example, protein might have a very good AA profile, but are unable to absorbed well and/or be digested in the body. Some studies have reported an increase in in vitro protein digestibility (IVPD) during the fermentation of cereals and legumes. An improved protein digestibility during fermentation was attributed to the release of protein from plant tissues by the enzymatic breakdown of dietary fibres, with a simultaneous reduction in/degradation of polyphenols, tannins and phytic acid by the action of microbial enzymes $[156,210,215]$. Polyphenols are known to bind to recognition/receptive sites of digestive enzymes, or crosslink with proteins; hence, limiting the hydrolysis reaction [211]. Furthermore, during fermentation, insoluble/complex storage proteins undergo perturbations in structural configurations, which render them more accessible and susceptible to attack by pepsin and endopeptidase that breaks down proteins into smaller peptides that are more soluble. Ogodo et al. [134] suggested that lower $\mathrm{pH}$ values obtained during fermentation may well promote the enzyme activity of peptidases and activate endogenous proteases, which increases peptides and the free AA concentration; hence, increasing protein solubility.

Wedad et al. [170] reported an IVPD increase of $0.49-31.3 \%$ in sorghum fermented with starter inoculum through SSF. Mohammed et al. [139] also reported an increase of $21 \%$ in fermented sorghum, and such an increase was due to the reduction in ANF during fermentation. An increase of 10\% was reported in IVPD of African yam bean (Table 4), and this was attributed to proteolysis, an increased availability of AAs and reduced ANFs [149]. An increase of $15.2 \%$ was reported in IVPD of chickpea fermented into tempeh flour and the authors attributed this to the elimination of undesirable factors (i.e., tannins during soaking and phytic acid during fermentation) as well as protein hydrolysis during fermentation, which resulted in proteins that were more vulnerable to enzyme action [178]. Additionally, an increase of $4.4 \%$ in IVPD of chickpea fermented with Cordyceps militaris was ascribed to the unfolding of the proteins during fermentation; thus, making them more accessible and easier to be hydrolysed by proteases [147]. On the contrary, during the fermentation of lupins into fermented lupin flour, Olukomaiya et al. [150] reported a 16-32.5\% decrease in IVPD, with the authors attributing this decrease to protein being locked within the fibre matrix and, thus, reducing the hydrolytic action of the enzymes as well as partial protein denaturation during drying, which might also lower protein dispersibility and solubility; thus, resulting in a reduced IVPD.

An increase in the in vitro bioavailability of iron (68.3-90.6\%) and zinc (86.7-100.6\%) was reported by Dhull et al. [185] in fermented lentils. The authors attributed this increase to the reduction in ANFs as well as compounds that formed complexes with zinc and iron in the unfermented flour. Significant increases in in vitro starch digestibility (IVSD) have been recorded for maize (Zea mays) flour fermentation with LAB-consortium from maize $(10.68-49.32 \%)$, LAB-consortium from sorghum (10.68-58\%) and natural fermentation (20.10-49.45\%) [156]. The enhanced digestibility was due to changes in the endosperm protein which allowed starch to become more accessible to the digestive enzymes [156]. 
The increase in IVSD in fermented sorghum (1.6-54\%) was equally attributed to changes in the endosperm protein fractions that allowed starch to become more accessible to the digestive enzymes [166].

\section{Conclusions and Future Perspectives}

It was evident from the various studies consulted in this review that fermentation, though being an ancient food processing practice, remains an important approach for increasing the level of nutrients, reducing antinutritional factors and enhancing nutrient bioaccessibility/bioavailability of cereals and legumes. Very often, fermentation does not only increase the availability and digestibility of nutrients, but also makes the food more appetizing and acceptable by improving its texture, aroma, flavour, etc., as well as rendering the food safer for consumption by reducing/degrading certain inherent toxins in the food crop. This established fermented foods an important part of diet and nutrition in many cultures around the world, particularly in developing countries, with limited access to sophisticated food processing techniques and infrastructure. Additionally, some of the microorganisms implicated in food fermentation have been linked with important health benefits. Based on inference from the reviewed literature, we see fermentation as an important process in the food production value chain. Indeed, fermentation is a complex process and food components do not necessarily exist in isolation, but as an entity. Accordingly, modifications in these constituents are influenced by the crop specie and cultivar, grain composition, fermenting microorganisms and the metabolism of these organisms. Additionally, important are the prior processing steps before and after fermentation. These intricacies tend to limit the understanding of food fermentation and insights into the mechanisms governing the modification in these components somewhat difficult. Hence, in order to fully exploit the benefits of fermentation, more research should be conducted, particularly focusing on modern microbial and biotechnological techniques, as well as the adoption of advanced techniques, including, but not limited to, metabolomics, metagenomics, metatranscriptomics, proteomics and artificial intelligence models to better optimize, standardize and describe the fermentation process for an overall improved food quality, enhanced nutrition and health as well as other associated socioeconomic benefits.

Author Contributions: J.A.A.: conceptualization, ideation and distribution of sections among authors, manuscript coordination and writing-original draft preparation; P.B.N.: conceptualization, supervision and review and editing of manuscript; S.G.: writing-section of the manuscript; A.B.O.: writing-section of the manuscript; O.M.O.: writing-section of the manuscript; S.A.O.: writing-section of the manuscript and editing of manuscript; O.A.A.: conceptualization, writing sections of the manuscript and review and editing of manuscript. All authors have read and agreed to the published version of the manuscript.

Funding: This work was supported via the National Research Foundation (NRF) of South Africa (120751), the University of Johannesburg Global Excellence and Stature (GES) 4.0 Catalytic Initiative Grant, the NRF Thuthuka Grant (121826) and the University of Johannesburg Research Committee Grant (URC).

Institutional Review Board Statement: Not applicable.

Informed Consent Statement: Not applicable.

Data Availability Statement: Not applicable.

Conflicts of Interest: The authors declare no conflict of interest.

\section{References}

1. Adebiyi, J.A.; Obadina, A.O.; Adebo, O.A.; Kayitesi, E. Fermented and malted millet products in Africa: Expedition from traditional/ethnic foods to industrial value-added products. Crit. Rev. Food Sci. Nutr. 2018, 58, 463-474. [CrossRef] [PubMed]

2. Adebo, O.A. African sorghum-based fermented foods: Past, current and future prospects. Nutrients 2020, 12, 1111. [CrossRef] [PubMed] 
3. Blandino, A.; Al-Aseeri, M.E.; Pandiella, S.S.; Cantero, D.; Webb, C. Cereal-based fermented foods and beverages. Food Res. Int. 2003, 36, 527-543. [CrossRef]

4. Tamang, J.P.; Cotter, P.D.; Endo, A.; Han, N.S.; Kort, R.; Liu, S.Q.; Mayo, B.; Westerik, N.; Hutkins, R. Fermented foods in a global age: East meets West. Compr. Rev. Food Sci. Food Saf. 2020, 19, 184-217. [CrossRef]

5. Adebo, O.A.; Oyeyinka, S.A.; Adebiyi, J.A.; Feng, X.; Wilkin, J.D.; Kewuyemi, Y.O.; Abrahams, A.M.; Tugizimana, F. Application of gas chromatography-mass spectrometry (GC-MS)-based metabolomics for the study of fermented cereal and legume foods: A review. Int. J. Food Sci. Technol. 2021, 56, 1514-1534. [CrossRef]

6. Aka, S.; Konan, G.; Fokou, G.; Dje, K.M.; Bassirou, B. Review on African traditional cereal beverages. Am. J. Res. Commun. 2014, 2, 103-153.

7. Brandt, M.J. Starter cultures for cereal-based foods. Food Microbiol. 2014, 37, 41-43. [CrossRef]

8. Adebo, O.A.; Njobeh, P.B.; Adeboye, A.S.; Adebiyi, J.A.; Sobowale, S.S.; Ogundele, O.M.; Kayitesi, E. Advances in fermentation technology for novel food products. In Innovations in Technologies for Fermented Food and Beverage Industries; Panda, S., Shetty, P., Eds.; Springer: London, UK, 2018; pp. 71-87.

9. Nkhata, S.G.; Ayua, E.; Kamau, E.H.; Shingiro, J.B. Fermentation and germination improve nutritional value of cereals and legumes through activation of endogenous enzymes. Food Sci. Nutr. 2018, 6, 2446-2458. [CrossRef]

10. Kewuyemi, Y.O.; Njobeh, P.B.; Kayitesi, E.; Adebiyi, J.A.; Oyedeji, A.B.; Adefisoye, M.A.; Adebo, O.A. Metabolite profile of whole grain ting (a Southern African fermented product) obtained using two strains of Lactobacillus fermentum. J. Cereal Sci. 2020, 95, 103042. [CrossRef]

11. Kumitch, H.M. The Effect of Solid-State Fermentation on Air-Classified Pea Protein-Enriched Flour to Improve the Digestibility and Functional Properties. Master's Thesis, University of Saskatchewan, Saskatoon, SK, Canada, 2019.

12. Adebo, O.A.; Medina-Meza, I.G. Impact of fermentation on the phenolic compounds and antioxidant activity of whole cereal grains: A mini review. Molecules 2020, 25, 927. [CrossRef]

13. Rollán, G.C.; Gerez, C.L.; LeBlanc, J.G. Lactic fermentation as a strategy to improve the nutritional and functional values of pseudocereals. Front. Nutr. 2019, 6, 98. [CrossRef] [PubMed]

14. Chaves-Lopez, C.; Serio, A.; Grande-Tovar, C.D.; Cuervo-Mulet, R.; Delgado-Ospina, J.; Paparella, A. Traditional fermented foods and beverages from a microbiological and nutritional perspective: The Colombian Heritage. Compr. Rev. Food Sci. Food Saf. 2014, 13, 1031-1048. [CrossRef]

15. Hlangwani, E.; Adebiyi, J.A.; Doorsamy, W.; Adebo, O.A. Processing, characteristics and composition of umqombothi (a South African traditional beer). Processes 2020, 8, 1451. [CrossRef]

16. Hassan, M.N.; Sultan, M.Z.; Mar-E-Um, M. Significance of fermented food in nutrition and food science. J. Sci. Res. 2014, 6 , 373-386. [CrossRef]

17. McFeeters, R.F. Effects of fermentation on nutritional properties of food. In Nutritional Evaluation of Food Processing, 3rd ed.; Karmas, E., Harris, R.S., Eds.; Van Nostrand Reinhold Company Inc.: New York, NY, USA, 1988; pp. $423-446$.

18. Li, P.; Liang, H.; Lin, W.-T.; Feng, F.; Luo, L. Microbiota dynamics associated with environmental conditions and potential roles of cellulolytic communities in traditional Chinese cereal starter solid-state fermentation. Appl. Environ. Microbiol. 2015, 81, 5144-5156. [CrossRef]

19. Odunfa, S.A.; Oyewole, O.B. African Fermented Foods; Blackie Academic and Professional: London, UK, 1997.

20. Eggum, B.O.; Monowar, L.; Back Knudsen, K.E.; Munck, L.; Axtell, J. Nutritional quality of sorghum and sorghum foods from Sudan. J. Cereal Sci. 1983, 1, 127-137. [CrossRef]

21. Marsh, A.J.; Hill, C.; Ross, R.P.; Cotter, P.D. Fermented beverages with health-promoting potential: Past and future perspectives. Trends Food Sci. Technol. 2014, 38, 113-124. [CrossRef]

22. Steinkraus, K.H. Handbook of Indigenous Fermented Food, 2nd ed.; Marcel Dekker, Inc.: New York, NY, USA, 1996.

23. Wang, H.L.; Hesseltine, C.W. Glossary of Indigenous Fermented Foods; Northern Regional Research Center, Agricultural Research Service, U.S. Department of Agriculture: Peoria, IL, USA, 2011.

24. Pérez-Cataluña, A.; Elizaquível, P.; Carrasco, P.; Espinosa, J.; Reyes, D.; Wacher, C.; Aznar, R. Diversity and dynamics of lactic acid bacteria in Atole agrio, a traditional maize-based fermented beverage from South-Eastern Mexico, analysed by high throughput sequencing and culturing. Antonie Van Leeuwenhoek 2018, 111, 385-399. [CrossRef]

25. Väkeväinen, K.; Valderrama, A.; Espinosa, J.; Centurión, D.; Rizo, J.; Reyes-Duarte, D.; Díaz-Ruiz, G.; von Wright, A.; Elizaquível, P.; Esquivel, K.; et al. Characterization of lactic acid bacteria recovered from Atole agrio, a traditional Mexican fermented beverage. LWT-Food Sci. Technol. 2018, 88, 109-118. [CrossRef]

26. Campbell-Platt, G. Fermented Foods of the World: A Dictionary and Guide; Butterworths: London, UK, 1987.

27. Tou, E.H.; Mouquet-River, C.; Rochette, I.; Traoré, A.S.; Treche., S.; Guyot, J.P. Effect of different process combinations on the fermentation kinetics, microflora and energy density of ben-saalga, a fermented gruel from Burkina Faso. Food Chem. 2007, 100, 935-943. [CrossRef]

28. Kolawole, O.M.; Kayode, R.M.O.; Akindayo, B. Proximate and microbial analyses of burukutu and pito produced in Ilorin. Nigeria Afr. J. Biotechnol. 2007, 6, 587-590.

29. Eze, V.C.; Eleke, O.I.; Omeh, Y.S. Microbiological and nutritional qualities of burukutu sold in mammy market Abakpa, Enugu State, Nigeria. Am. J. Food Nutr. 2011, 1, 141-146. [CrossRef] 
30. Alo, M.N.; Eze, U.A.; Eda, N.E. Microbiological qualities of burukutu produced from a mixture of sorghum and millet. Am. J. Food Nutr. 2012, 2, 96-102.

31. Mwale, M.M. Microbiological Quality and Safety of the Zambian Fermented Cereal Beverage: Chibwantu. Ph.D. Thesis, University of Free State, Bloemfontein, South Africa, 2014.

32. Worku, B.B.; Gemede, H.F.; Woldegiorgis, A.Z. Nutritional and alcoholic contents of cheka: A traditional fermented beverage in Southwestern Ethiopia. Food Sci. Nutr. 2018, 6, 2466-2472. [CrossRef] [PubMed]

33. Gadaga, T.H.; Mutakumira, A.N.; Narvhus, J.A.; Ferusu, S.B. A review of traditional fermented foods and beverages in Zimbabwe. Int. J. Food Microbiol. 1999, 53, 1-11. [CrossRef]

34. Togo, A.H.; Ferusa, B.S.; Mutukumira, N.A. Identification of lactic acid bacteria isolated from opaque beer (chibuku) for potential use as a starter culture. J. Food Technol. Afr. 2002, 7, 93-97. [CrossRef]

35. Bassi, D.; Orrù, L.; Vasquez, J.C.; Cocconcelli, P.S.; Fontana, C. Peruvian chicha: A focus on the microbial populations of this ancient maize-based fermented beverage. Microorganisms 2020, 8, 93. [CrossRef] [PubMed]

36. Abriouel, H.; Omar, N.B.; López, R.L.; Martinez-Caňamero, M.; Keleke, S.; Gálvez, A. Culture-independent analysis of the microbial composition of the African traditional fermented foods poto poto and dégué. Int. J. Food Microbiol. 2006, 111, 228-233. [CrossRef] [PubMed]

37. Assohoun-Djeni, N.M.C.; Djeni, N.T.; Messaoudi, S.; Lhomme, E.; Koussemon-Camara, M.; Ouassa, T.; Chobert, J.M.; Onno, B.; Dousset, $X$. Biodiversity, dynamics and antimicrobial activity of lactic acid bacteria involved in the fermentation of maize flour for doklu production in Côte d'Ivoire. Food Control 2016, 62, 397-404. [CrossRef]

38. Van der Aa Kühle, A.; Jespersen, L.; Glover, R.L.; Diawara, B.; Jakobsen, M. Identification and characterization of Saccharomyces cerevisiae strains isolated from West African sorghum beer. Yeast 2001, 18, 1069-1079. [CrossRef] [PubMed]

39. Sawadogo-Lingani, H.; Lei, V.; Diawara, B.; Nielsen, D.S.; Moller, P.L.; Traore, A.S.; Jakobsen, M. The biodiversity of predominant lactic acid bacteria in dolo and pito wort, for production of sorghum beer. J. Appl. Microbiol. 2007, 103, 765-777. [CrossRef] [PubMed]

40. Mukisa, I.M.; Ntaate, D.; Byakika, S. Application of starter cultures in the production of Enturire-A traditional sorghum-based alcoholic beverage. Food Sci. Nutr. 2017, 5, 609-616. [CrossRef] [PubMed]

41. Greppi, A.; Rantsiou, K.; Padonou, W.; Hounhouigan, J.; Jespersen, L.; Jakobsen, M.; Cocolin, L. Determination of yeast diversity in ogi, mawè, gowé and tchoukoutou by using culture-dependent and-independent methods. Int. J. Food Microbiol. 2013, 165, 84-88. [CrossRef] [PubMed]

42. Adinsi, L.; Vieira-Dalode, G.; Akissoe, N.H.; Anihouvi, V.; Mestres, C.; Jacobs, A.; Dlamini, N.; Pallet, D.; Hounhouigan, J.D. Processing and quality attributes of gowe: A malted and fermented cereal-based beverage from Benin. Food Chain 2014, 4, 171-183. [CrossRef]

43. Yousif, N.M.K.; Huch, M.; Schuster, T.; Cho, G.S.; Dirar, H.A.; Holzapfel, W.H.; Franz, C.M.A.P. Diversity of lactic acid bacteria from Hussuwa, a traditional African fermented sorghum food. Food Microbiol. 2010, 27, 757-768. [CrossRef]

44. Olasupo, N.A.; Odunfa, S.A.; Obayori, O.S. Ethnic African fermented foods. In Fermented Foods and Beverages of the World; Tamang, J.P., Kailasapathy, K., Eds.; CRC Press, Taylor \& Francis Group: New York, NY, USA, 2010; pp. 323-352.

45. Kanwar, S.S.; Gupta, M.K.; Katoch, C.; Kumar, R.; Kanwar, P. Traditional fermented foods of Lahul and Spiti area of Himachal Pradesh. Indian J. Tradit. Knowl. 2007, 6, 42.

46. Tafere, G. A review on traditional fermented beverages of Ethiopian. J. Nat. Sci. Res. 2015, 5, 94-102.

47. Kohajdová, Z. Fermented cereal products. In Current Developments in Biotechnology and Bioengineering; Elsevier: Amsterdam, The Netherlands, 2017; pp. 91-117.

48. Mohammed, S.I.; Steenson, L.R.; Kirleis, A.W. Isolation and characterization of microorganisms associated with traditional sorghum fermentation for production of Sudanese kisra. Appl. Environ. Microbiol. 1991, 57, 2529-2533. [CrossRef]

49. Hamad, S.H.; Dieng, M.C.; Ehrmann, M.A.; Vogel, R.F. Characterization of the bacterial flora of Sudanese sorghum flour and sorghum sourdough. J. Appl. Microbiol. 1997, 3, 764-770. [CrossRef]

50. Von Mollendor, J.W.; Vaz-Velho, M.; Todorov, S.D. Boza, a traditional cereal-based fermented beverage: A rich source of probiotics and bacteriocin-producing lactic acid bacteria. In Functional Properties of Traditional Foods; Kristbergsson, K., Ötles, S., Eds.; Springer: Boston, MA, USA, 2016; pp. 157-188.

51. Franz, C.M.A.P.; Holzapfel, W.H. Examples of lactic-fermented foods of the African continent. In Lactic Acid Bacteria: Microbiological and Functional Aspects; Vinderola, G., Ouwehand, A., Salminen, S., von Wright, A., Eds.; CRC Press: Boca Raton, FL, USA, 2019; pp. 235-254.

52. Tchikoua, R.; Tatsadjieu, N.L.; Mbofung, C.M.F. Effect of selected lactic acid bacteria on growth of Aspergillus flavus and Aflatoxin B1 production in kutukutu. J. Microbiol. Res. 2015, 5, 84-94.

53. Prado, F.C.; Parada, J.L.; Pandey, A.; Soccol, C.R. Trends in non-dairy probiotic beverages. Food Res. Int. 2008, 41, 111-123. [CrossRef]

54. Franz, C.M.; Huch, M.; Mathara, J.M.; Abriouel, H.; Benomar, N.; Reid, G.; Galvez, A.; Holzapfel, W.H. African fermented foods and probiotics. Int. J. Food Microbiol. 2014, 190, 84-96. [CrossRef] [PubMed]

55. Hounhouigan, D.J.; Nout, M.J.; Nago, C.M.; Houben, J.H.; Rombouts, F.M. Characterization and frequency distribution of species of lactic acid bacteria involved in the processing of mawé, a fermented maize dough from Benin. Int. J. Food Microbiol. 1993, 18, 279-287. [CrossRef] 
56. Agati, V.; Guyot, J.P.; Morlon-Guyot, J.; Talamond, P.; Hounhouigan, D.J. Isolation and characterization of new amylolytic strains of Lactobacillus fermentum from fermented maize doughs (mawè and ogi) from Benin. J. Appl. Microbiol. 1998, 85, 512-520. [CrossRef]

57. Schoustra, S.E.; Kasase, C.; Toarta, C.; Poulain, A.J. Microbial community structure of three traditional Zambian fermented products: Mabisi, Chibwantu and Munkoyo. PLoS ONE 2013, 6, 112. [CrossRef]

58. Kuye, A.; Sanni, L.O. Industrialization of fermented food processes: How far in Nigeria? J. Sci. Ind. Res. 1999, $58,83743$.

59. Omemu, A.M.; Bankole, M.O. Consumer's knowledge, attitude, usage and storage pattern of ogi-A fermented cereal gruel in Southwest, Nigeria. Food Public Health 2015, 5, 77-83.

60. Oriola, O.B.; Boboye, B.E.; Adetuyi, F.C. Bacterial and fungal communities associated with the production of a Nigerian fermented beverage, "otika". Jordan J. Biol. Sci. 2017, 10, 127-133.

61. Kotaka, A.; Bando, H.; Kaya, M.; Kato-Murai, M.; Kuroda, K.; Sahara, H.; Hata, Y.; Kondo, A.; Ueda, M. Direct ethanol production from barley $\beta$-glucan by sake yeast displaying Aspergillus oryzae $\beta$-glucosidase and endoglucanase. J. Biosci. Bioeng. 2008, 105, 622-627. [CrossRef]

62. Ray, S.S.; Raychaudhuri, U.; Chakraborty, R. Rice-, pulse-, barley-, and oat-based fermented food products. Cereal Foods World 2015, 60, 218-223. [CrossRef]

63. Djè, K.M.; Aka, S.; Zinzendorf, N.Y.; Yao, K.C.; Loukou, Y.G. Predominant lactic acid bacteria involved in the spontaneous fermentation step of tchapalo process, a traditional sorghum beer of Côte d'Ivoire. Res. J. Biol. Sci. 2009, 4, 789-795.

64. N'guessan, K.F.; Brou, K.; Jacques, N.; Casaregola, S.; Djè, K.M. Identification of yeasts during alcoholic fermentation of tchapalo, a traditional sorghum beer from Côte d'Ivoire. Antonie Van Leeuwenhoek 2011, 99, 855-864. [CrossRef] [PubMed]

65. Kayodé, A.P.P.; Hounhouigana, J.D.; Nout, M.J.R. Impact of brewing process operations on phyta, phenolic compounds and in vitro solubility of iron and zinc in opaque sorghum beer. LWT-Food Sci. Technol. 2007, 40, 834-841. [CrossRef]

66. Greppi, A.; Rantsiou, K.; Padonou, W.; Hounhouigan, J.; Jespersen, L.; Jakobsen, M.; Cocolin, L. Yeast dynamics during spontaneous fermentation of mawè and tchoukoutou, two traditional products from Benin. Int. J. Food Microbiol. 2013, 165, $200-207$. [CrossRef] [PubMed]

67. Madoroba, E.; Steenkamp, E.T.; Theron, J.; Huys, G.; Scheirlinck, I.; Cloete, T.E. Polyphasic taxonomic characterization of lactic acid bacteria isolated from spontaneous sorghum fermentations used to produce ting, a traditional South African food. Afr. J. Biotechnol. 2009, 8, 458-463.

68. Madoroba, E.; Steenkamp, E.T.; Theron, J.; Scheirlinck, I.; Cloete, T.E.; Huys, G. Diversity and dynamics of bacterial populations during spontaneous sorghum fermentations used to produce ting, a South African food. Syst. Appl. Microbiol. 2011, 34, 227-234. [CrossRef] [PubMed]

69. Sekwati-Monang, B.; Gänzle, M.G. Microbiological and chemical characterization of ting, a sorghum-based sourdough product from Botswana. Int. J. Food Microbiol. 2011, 150, 115-121. [CrossRef]

70. Adebo, O.A.; Kayitesi, E.; Tugizimana, F.; Njobeh, P.B. Differential metabolic signatures in naturally and lactic acid bacteria (LAB) fermented ting (a Southern African food) with different tannin content, as revealed by gas chromatography mass spectrometry (GC-MS)-based metabolomics. Food Res. Int. 2019, 121, 326-335. [CrossRef] [PubMed]

71. Nout, M.J.R. Rich Nutrition from the poorest-Cereal fermentations in Africa and Asia. Food Microbiol. 2009, 26, 685-692. [CrossRef]

72. Katongole, J.N. The Microbial Succession in Indigenous Fermented Maize Products. Master's Thesis, University of Free State, Bloemfontein, South Africa, 2008.

73. Van der Walt, J. Better Kaffir beer. S. Afr. J. Sci. 1954, 50, 221.

74. Singh, T.A.; Devi, K.R.; Ahmed, G.; Jeyaram, K. Microbial and endogenous origin of fibrinolytic activity in traditional fermented foods of Northeast India. Food Res. Int. 2014, 55, 356-362. [CrossRef]

75. Hossain, M.; Kabir, Y. Ethnic Fermented Foods and Beverages of Bangladesh. In Ethnic Fermented Foods and Alcoholic Beverages of Asia; Tamang, J.P., Ed.; Springer: New Delhi, India, 2016; pp. 73-89.

76. Rawat, K.; Kumari, A.; Kumar, S.; Kumar, R.; Gehlot, R. Traditional fermented products of India. Int. J. Curr. Microbiol. Appl. Sci. 2018, 7, 1873-1883. [CrossRef]

77. Chettri, R. Microbiological Evaluation of turangbai and bekang, Ethnic Fermented Soybean foods of Northeast India. Ph.D. Thesis, North Bengal University, Siliguri, India, 2013.

78. Rani, D.K.; Soni, S.K. Applications and commercial uses of microorganisms. In Microbes: A Source of Energy for 21st Century; Soni, S.K., Ed.; Jai Bharat Printing Press: Delhi, India, 2007; Chapter 2; pp. 71-126.

79. Shin, D.; Kwon, D.; Kim, Y.; Jeong, D. Science and Technology of Korean Gochujang; Public Health Edu: Seoul, Korea, $2012 ;$ pp. 10-133.

80. Sha, S.P.; Ghatani, K.; Tamang, J.P. Dalbari, a traditional pulse based fermented food of West Bangal. Int. J. Agric. Food Sci. Technol. 2013, 4, 6-10.

81. Amadi, E.N.; Barimalaa, I.S.; Omosigho, J. Influence of temperature on the fermentation of Bambara groundnut (Vigna subterranea), to produce a dawadawa-type product. Plant Foods Hum. Nutr. 1999, 54, 13-20. [CrossRef] [PubMed]

82. Frias, J.; Penas, E.; Martinez-Villaluenga, C. Fermented pulses in nutrition and health promotion. In Fermented Foods in Health and Disease Prevention; Frias, J., Martinez-Villaluenga, C., Penas, E., Eds.; Academic Press: Cambridge, MA, USA, 2016 ; pp. 385-416.

83. Akanni, G.B.; Naudé, Y.; de Kock, H.L.; Buys, E.M. Diversity and functionality of bacillus species associated with alkaline fermentation of Bambara groundnut (Vigna subterranean L. Verdc) into dawadawa-type African condiment. Eur. Food Res. Technol. 2018, 244, 1147-1158. [CrossRef] 
84. Soni, S.K.; Sandhu, D.K.; Vilkhu, K.S.; Kamra, N. Microbiological studies on dosa fermentation. Food Microbiol. 1986, 3, 45-53. [CrossRef]

85. Zhang, J.H.; Tatsumi, E.; Fan, J.F.; Li, L.T. Chemical components of Aspergillus-type Douchi, a Chinese traditional fermented soybean product, change during the fermentation process. Int. J. Food Sci. Technol. 2007, 42, 263-268. [CrossRef]

86. Chen, T.; Jiang, S.; Xiong, S.; Wang, M.; Zhu, D.; Wei, H. Application of denaturing gradient gel electrophoresis to microbial diversity analysis in Chinese Douchi. J. Sci. Food Agric. 2012, 92, 2171-2176. [CrossRef]

87. Sumino, T.; Endo, E.; Kageyama, A.S.; Chihihara, R.; Yamada, K. Various components and bacteria of furu (soybean cheese). J. Cook. Sci. Jpn. 2003, 36, 157-163.

88. Kim, T.W.; Lee, J.W.; Kim, S.E.; Park, M.H.; Chang, H.C.; Kim, H.Y. Analysis of microbial communities in doenjang, a Korean fermented soybean paste using nested PCR-denaturing gradient gel electrophoresis. Int. J. Food Microbiol. 2009, 131, $265-271$. [CrossRef]

89. Nam, Y.-D.; Lee, S.-Y.; Lim, S.-I. Microbial community analysis of Korean soybean pastes by next generation sequencing. Int. J. Food Microbiol. 2012, 155, 36-42. [CrossRef] [PubMed]

90. Jeyaram, K.; Singh, W.M.; Premarani, T.; Ranjita Devi, A.; Chanu, K.S.; Talukdar, N.C.; Singh, M.R. Molecular identification of dominant microflora associated with 'Hawaijar' - A traditional fermented soybean (Glycine max L.) food of Manipur, India. Int. J. Food Microbiol. 2008, 122, 259-268. [CrossRef] [PubMed]

91. Sridevi, J.; Halami, P.M.; Vijayendra, S.V.N. Selection of starter cultures for idli batter fermentation and their effect on quality of idli. J. Food Sci. Technol. 2010, 47, 557-563. [CrossRef] [PubMed]

92. Meerak, J.; Yukphan, P.; Miyashita, M.; Sato, H.; Nakagawa, Y.; Tahara, Y. Phylogeny of $\gamma$-polyglutamic acid-producing Bacillus strains isolated from a fermented locust bean product manufactured in West Africa. J. Gen. Appl. Microbiol. 2008, 54, 159-166. [CrossRef] [PubMed]

93. Dirar, H.A.; Harper, D.B.; Collins, M.A. Biochemical and microbiological studies on kawal, a meat substitute derived by fermentation of Cassia obtusifolia leaves. J. Sci. Food Agric. 2006, 36, 881-892. [CrossRef]

94. Alexandraki, V.; Tsakalidou, E.; Papadimitriou, K.; Holzapfel, W.H. Status and Trends of the Conservation and Sustainable Use of Microorganisms in Food Processes; Commission on Genetic Resources for Food and Agriculture. FAO Background Study Paper No. 65; FAO: Rome, Italy, 2013.

95. Tamang, J.P. Native microorganisms in fermentation of kinema. Ind. J. Microbiol. 2003, 43, 127-130.

96. Kumar, J.; Sharma, N.; Girija Kaushal, G.; Samurailatpam, S.; Sahoo, D.; Rai, A.K.; Singh, S.P. Metagenomic insights into the taxonomic and functional features of kinema, a traditional fermented soybean product of Sikkim Himalaya. Front. Microbiol. 2019, 10, 1744. [CrossRef]

97. Ramakrishnan, C.V. Studies on Indian fermented foods. Baroda J. Nutr. 1979, 6, 1-54.

98. Sugawara, E. Fermented soybean pastes miso and shoyu with reference to aroma. In Fermented Foods and Beverages of the World; Tamang, J.P., Kailasapathy, K., Eds.; CRC Press, Taylor \& Francis Group: New York, NY, USA, 2010; pp. $225-245$.

99. Chettri, R.; Tamang, J.P. Microbiological evaluation of maseura, an ethnic fermented legume-based condiment of Sikkim. J. Hill Res. 2008, 21, 1-7.

100. Sharma, N.; Handa, S.; Gupta, A. A comprehensive study of different traditional fermented foods/beverages of Himachal Pradesh to evaluate their nutrition impact on health and rich biodiversity of fermenting microorganisms. Int. J. Res. Appl. Nat. Soc. Sci. 2013, 3, 19-28.

101. Dahal, N.R.; Karki, T.B.; Swamylingappa, B.; Li, Q.; Gu, G. Traditional foods and beverages of Nepal—A review. Food Rev. Int. 2005, 21, 1-25. [CrossRef]

102. Dahal, N.R.; Rao, E.R.; Swamylingappa, B. Biochemical and nutritional evaluation of Masyaura-A legume based traditional savory of Nepal. J. Food Sci. Technol. 2013, 1, 17-22.

103. Zhu, Y.P.; Cheng, Y.Q.; Wang, L.J.; Fan, J.F.; Li, L.T. Enhanced antioxidative activity of Chinese traditionally fermented Okara (Meitauza) prepared with various microorganism. Int. J. Food Prop. 2008, 11, 519-529. [CrossRef]

104. Choi, S.H.; Lee, M.H.; Lee, S.K.; Oh, M.J. Microflora and enzyme activity of conventional meju and isolation of useful mould. Kor. J. Agric. Sci. 1995, 22, 188-196.

105. Asahara, N.; Zhang, X.B.; Ohta, Y. Antimutagenicity and mutagen-binding activation of mutagenic pyrolyzates by microorganisms isolated from Japanese miso. J. Sci. Food Agric. 2006, 58, 395-401. [CrossRef]

106. Khairil Anwar, N.A.K.; Idris, A.; Hassan, N. Isolation and identification of halophilic microorganisms in soy sauce. Food Res. 2020, 4, 84-87. [CrossRef]

107. Nagai, T.; Tamang, J.P. Fermented soybeans and non-soybeans legume foods. In Fermented Foods and Beverages of the World; Tamang, J.P., Kailasapathy, K., Eds.; CRC Press, Taylor \& Francis Group: New York, NY, USA, 2010; pp. 191-224.

108. Okoronkwo, N.E.; Emeh, I.C.; Onwuchekwa, E.C. Evaluation of phytochemical compositions and microbial load of raw and traditionally processed Ricinus communis seed (Ogiri). Am. J. NutR. Food Sci. 2015, 1, 21-26.

109. Balogun, M.A.; Oyeyiola, G.P. Microbiological and chemical changes during the production of Okpehe from Prosopis africana Seeds. J. Asian Sci. Res. 2011, 1, 390-398.

110. Ho, C.C. Identity and characteristics of Neurospora intermedia responsible for oncom fermentation in Indonesia. Food Microbiol. 1986, 3, 115-132. [CrossRef] 
111. Ezekiel, O.O.; Ogunshe, A.A.O.; Jegede, D.E. Controlled fermentation of cotton seeds (Gossypium hirsutum) for Owoh production using bacteria starter cultures. Niger. Food J. 2015, 33, 54-60. [CrossRef]

112. Noda, F.; Hayashi, K.; Mizunuma, T. Antagonism between osmophilic lactic acid bacteria and yeasts in brine fermentation of soy sauce. Appl. Envviron. Microbiol. 1980, 40, 452-457. [CrossRef] [PubMed]

113. Inamori, K.; Miyauchi, K.; Uchida, K.; Yoshino, H. Interaction between Pediococcus halophilus and Saccharomyces rouxii (microorganisms involved in shoyu moromi fermentation. Part I). Nipp. Nougeik. Kaishi 1984, 58, 771-777. [CrossRef]

114. Ouoba, L.; Cantor, M.; Diawara, B.; Traoré, A.; Jakobsen, M. Degradation of African locust bean oil by Bacillus subtilis and Bacillus pumilus isolated from soumbala, a fermented African locust bean condiment. J. Appl. Microbiol. 2003, 95, 868-873. [CrossRef] [PubMed]

115. Ouoba, L.; Diawara, B.; Wk, A.A.; Traore, A.; Moller, P. Genotyping of starter cultures of Bacillus subtilis and Bacillus pumilus for fermentation of African locust bean (Parkia biglobosa) to produce Soumbala. Int. J. Food Microbiol. 2004, 90, 197-205. [CrossRef]

116. Han, B.Z.; Beumer, R.R.; Rombouts, F.M.; Nout, M.J.R. Microbiological safety and quality of commercial sufu-A Chinese fermented soybean food. Food Control 2001, 12, 541-547. [CrossRef]

117. Kanlayakrit, W.; Phromsak, K. Novel conditions for tofu and pehtze preparation to overcome bacterial contamination in pehtze. Int. Food Res. J. 2014, 21, 335-342.

118. Winarno, F.G.; Fardiaz, S.; Daulay, D. Indonesian Fermented Foods; Department of Agricultural Product Technology, Fatema, Bogor Agricultural University: Bogor City, Indonesia, 1973.

119. Thakur, N.; Savitri; Bhalla, T.C. Characterization of some traditional fermented foods and beverages of Himachal Pradesh. Ind. J. Trad. Knowl. 2004, 3, 325-335.

120. Nout, M.J.R.; Kiers, J.L. Tempeh fermentation, innovation and functionality: Update into the third millennium. J. Appl. Microbiol. 2005, 98, 789-805. [CrossRef] [PubMed]

121. Jennessen, J.; Schnürer, J.; Olsson, J.; Samson, R.A.; Dijiksterhuis, J. Morphological characteristics of sporangiospores of the tempeh fungus Rhizopus oligosporus differentiate it from other taxa of the R. microsporus group. Mycol. Res. 2008, 112, 547-563. [CrossRef]

122. Kwon, Y.S.; Lee, S.; Lee, S.H.; Kim, H.J.; Lee, C.H. Comparative evaluation of six traditional fermented soybean products in East Asia: A metabolomics approach. Metabolites 2019, 9, 183. [CrossRef] [PubMed]

123. Chunhachart, O.; Itoh, T.; Sukchotiratana, M.; Tanimoto, H.; Tahara, Y. Characterization of $\gamma$-glutamyl hydrolase produced by Bacillus sp. isolated from Thai thuanao. Biosci. Biotechnol. Biochem. 2006, 70, 2779-2782. [CrossRef] [PubMed]

124. Chao, S.-H.; Tomii, Y.; Watanabe, K.; Tsai, Y.-C. Diversity of lactic acid bacteria in fermented brines used to make stinky tofu. Int. J. Food Microbiol. 2008, 123, 134-141. [CrossRef] [PubMed]

125. Okorie, P.C.; Olasupo, N.A. Growth and extracellular enzyme production by microorganisms isolated from Ugba-an indigenous Nigerian fermented food. Afr. J. Biotechnol. 2013, 12, 4158-4167.

126. Zheng, J.; Wittouck, S.; Salvetti, E.; Franz, C.M.; Harris, H.; Mattarelli, P.; Toole, P.W.; Pot, B.; Vandamme, P.; Jens Walter, J.; et al. A taxonomic note on the genus Lactobacillus: Description of 23 novel genera, emended description of the genus Lactobacillus Beijerinck 1901, and union of Lactobacillaceae and Leuconostocaceae. Int. J. Syst. Evol. Microbiol. 2000, 70, 2782-2858. [CrossRef] [PubMed]

127. Adhikari, B.M.; Adelakun, O.E.; Katawal, S.B. Physicochemical properties of fermented wheat-chickpea-rice weaning blend. Nutr. Food Sci. 2013, 43, 517-526. [CrossRef]

128. Adebiyi, J.A.; Obadina, A.O.; Adebo, O.A.; Kayitesi, E. Comparison of nutritional quality and sensory acceptability of biscuits obtained from native, fermented, and malted pearl millet (Pennisetum glaucum) flour. Food Chem. 2017, 233, 210-217. [CrossRef] [PubMed]

129. Inyang, C.U.; Zakari, U.M. Effect of germination and fermentation of pearl millet on proximate, chemical and sensory properties of instant "fura"-A Nigerian cereal food. Pak. J. Nutr. 2008, 7, 9-12. [CrossRef]

130. Espinosa-Páez, E.; Alanis-Guzmán, M.G.; Hernández-Luna, C.E.; Báez-González, J.G.; Amaya-Guerra, G.A.; Andrés-Grau, A Increasing antioxidant activity and protein digestibility in Phaseolus vulgaris and Avenasativa by fermentation with the Pleurotus ostreatus fungus. Molecules 2017, 22, 2275. [CrossRef]

131. Osman, M.A. Effect of traditional fermentation process on the nutrient and antinutrient contents of pearl millet during preparation of Lohoh. J. Saudi Soc. Agric. Sci. 2011, 10, 1-6. [CrossRef]

132. Mihiret, K.A. The Effect of Natural Fermentation on Some Antinutritional Factors, Minerals, Proximate Composition and Sensory Characteristics in Sorghum Based Weaning Food. Master's. Thesis, Addis Ababa University, Addis Ababa, Ethiopia, 2009.

133. Ilowefah, M.; Bakar, J.; Ghazali, H.M.; Mediani, A.; Muhammad, K. Physicochemical and functional properties of yeast fermented brown rice flour. J. Food Sci. Technol. 2015, 52, 5534-5545. [CrossRef]

134. Suarti, B.; Sukarno; Ardiansyah; Budijanto, S. Bio-active compounds, their antioxidant activities, and the physicochemical and pasting properties of both pigmented and non-pigmented fermented de-husked rice flour. AIMS Agric. Food 2021, 6, 49-64. [CrossRef]

135. Onyimba, I.A.; Ogbonna, C.I.C.; Akueshi, C.O.; Chukwu, C.O.C. Changes in the nutrient composition of brewery spent grain subjected to solid state natural fermentation. Niger. J. Biotechnol. 2009, 20, 55-60.

136. Ogodo, A.C.; Ugbogu, O.C.; Onyeagba, R.A.; Okereke, H.C. Microbiological quality, proximate composition and in vitro starch/protein digestibility of Sorghum bicolor flour fermented with lactic acid bacteria consortia. Chem. Biol. Technol. Agric. 2019, 6, 1-9. [CrossRef] 
137. Nnam, N.M.; Obiakor, P.N. Effect of fermentation on the nutrient and antinutrient composition of baobab (Adansonia digitata) seeds and rice (Oryza sativa) grains. Ecol. Food Nutr. 2003, 42, 265-277. [CrossRef] [PubMed]

138. Ejigui, J.; Savoie, L.; Marin, J.; Desrosiers, T. Beneficial changes and drawbacks of a traditional fermentation process on chemical composition and antinutritional factors of yellow maize (Zea mays). J. Biol. Sci. 2005, 5, 590-596.

139. Mohammed, N.A.; Ahmed, I.A.M.; Babiker, E.E. Nutritional evaluation of sorghum flour (Sorghum bicolor L. Moench) during processing of Injera. World Acad. Sci. Eng. Technol. 2011, 51, 72-76.

140. Oladeji, B.S.; Irinkoyenikan, O.A.; Akanbi, C.T.; Gbadamosi, S.O. Effect of fermentation on the physicochemical properties, pasting profile and sensory scores of normal endosperm maize and quality protein maize flours. Int. Food Res. J. 2018, 25, $1100-1108$.

141. Curiel, J.A.; Coda, R.; Centomani, I.; Summo, C.; Gobbetti, M.; Rizzello, C.G. Exploitation of the nutritional and functional characteristics of traditional Italian legumes: The potential of sourdough fermentation. Int. J. Food Microbiol. 2015, $196,51-61$. [CrossRef]

142. Adebiyi, J.A.; Njobeh, P.B.; Kayitesi, E. Assessment of nutritional and phytochemical quality of Dawadawa (an African fermented condiment) produced from Bambara groundnut (Vigna subterranea). Microchem. J. 2019, 149, 104034. [CrossRef]

143. Kumitch, H.M.; Stone, A.; Nosworthy, M.G.; Nickerson, M.T.; House, J.D.; Korber, D.R.; Tanaka, T. Effect of fermentation time on the nutritional properties of pea protein-enriched flour fermented by Aspergillus oryzae and Aspergillus niger. Cereal Chem. 2020, 97, 104-113. [CrossRef]

144. Akubor, P.I.; Chukwu, J.K. Proximate composition and selected functional properties of fermented and unfermented African oil bean (Pentaclethra macrophylla) seed flour. Plant Foods Hum. Nutr. 1999, 54, 227-238. [CrossRef] [PubMed]

145. Adebowale, O.J.; Maliki, K. Effect of fermentation period on the chemical composition and functional properties of pigeon pea (Cajanus cajan) seed flour. Int. Food Res. J. 2011, 18, 1329-1333.

146. Difo, H.V.; Onyike, E.; Ameh, D.A.; Ndidi, U.S.; Njoku, G.C. Chemical changes during open and controlled fermentation of cowpea (Vigna unguiculata) flour. Int. J. Food Nutr. Saf. 2014, 5, 1-10.

147. Xiao, Y.; Xing, G.; Rui, X.; Li, W.; Chen, X.; Jiang, M.; Dong, M. Effect of solid-state fermentation with Cordyceps militaris SN-18 on physicochemical and functional properties of chickpea (Cicer arietinum L.) flour. LWT-Food Sci Technol. 2015, 63, 1317-1324. [CrossRef]

148. Xiao, Y.; Sun, M.; Zhang, Q.; Chen, Y.; Miao, J.; Rui, X.; Dong, M. Effects of Cordyceps militaris (L.) Fr. fermentation on the nutritional, physicochemical, functional properties and angiotensin I converting enzyme inhibitory activity of red bean (Phaseolus angularis [Willd.] W.F. Wight.) flour. J. Food Sci. Technol. 2018, 55, 1244-1255. [CrossRef] [PubMed]

149. Chinma, E.C.; Azeez, S.O.; Sulayman, H.T.; Alhassan, K.; Alozie, S.N.; Gbadamosi, H.D.; Danbaba, N.; Oboh, H.A.; Anuonye, J.C.; Adebo, O.A. Evaluation of fermented African yam bean flour composition and influence of substitution levels on properties of wheat bread. J. Food Sci. 2020, 85, 4281-4289. [CrossRef] [PubMed]

150. Olukomaiya, O.O.; Adiamo, O.Q.; Fernando, W.C.; Mereddy, R.; Li, X.; Sultanbawa, Y. Effect of solid-state fermentation on proximate composition, anti-nutritional factor, microbiological and functional properties of lupin flour. Food Chem. 2020, 315, 126238. [CrossRef]

151. Obadina, A.O.; Akinola, O.J.; Shittu, T.A.; Bakare, H.A. Effect of natural fermentation on the chemical and nutritional composition of fermented soymilk nono. Niger. Food J. 2013, 31, 91-97. [CrossRef]

152. Barampama, Z.; Simard, R.E. Effects of soaking, cooking and fermentation on composition, in-vitro starch digestibility and nutritive value of common beans. Plant Foods Hum. Nutr. 1995, 48, 349-365. [CrossRef]

153. Asensio-Grau, A.; Calvo-Lerma, J.; Heredia, A.; Andrés, A. Enhancing the nutritional profile and digestibility of lentil flour by solid state fermentation with Pleurotus ostreatus. Food Funct. 2020, 11, 7905-7912. [CrossRef]

154. Nivetha, N.; Suvarna, V.C.; Abhishek, R.U. Reduction of phenolics, tannins and cyanogenic glycosides contents in fermented beverage of linseed (Linum usitatissimum). Int. J. Food Ferment. Technol. 2018, 8, 185-190. [CrossRef]

155. Mohiedeen, I.E.; El Tinay, A.H.; Elkhalifa, A.O.; Babiker, E.E.; Mallasy, L.O. Effect of fermentation and cooking on protein quality of maize (Zea mays L.) cultivars. Int. J. Food Sci. Technol. 2010, 45, 1284-1290. [CrossRef]

156. Ogodo, A.C.; Ugbogu, O.C.; Onyeagba, R.A.; Okereke, H.C. Effect of lactic acid bacteria consortium fermentation on the proximate composition and in-vitro starch/protein digestibility of maize (Zea mays) flour. Am. J. Microbiol. Biotechnol. 2017, 4, 35-43.

157. Ongol, M.P.; Niyonzima, E.; Gisanura, I.; Vasanthakaalam, H. Effect of germination and fermentation on nutrients in maize flour. Pak. J. Food Sci. 2013, 23, 183-188.

158. Akinola, S.A.; Badejo, A.A.; Osundahunsi, O.F.; Edema, M.O. Effect of pre-processing techniques on pearl millet flour and changes in technological properties. Int. J. Food Sci. Technol. 2017, 52, 992-999. [CrossRef]

159. Khetarpaul, N.; Chauhan, B.M. Effect of germination and fermentation on in vitro starch and protein digestibility of pearl millet. J. Food Sci. 1990, 55, 883-884. [CrossRef]

160. Mahajan, S.; Chauhan, B.M. Effect of natural fermentation on the extractability of minerals from pearl millet flour. J. Food Sci. 1988, 53, 1576-1577. [CrossRef]

161. Ilowefah, M.; Chinma, E.C.; Bakar, J.; Ghazali, H.M.; Muhammad, K. Enhancement of extruded brown rice flour functionality through fermentation. Acta Sci. Nutr. Health 2018, 2, 2-10. 
162. Kupski, L.; Cipolatti, E.; da Rocha, M.; dos Santos Oliveira, M.; de Almeida Souza-Soares, L.; Badiale-Furlong, B. Solid-state fermentation for the enrichment and extraction of proteins and antioxidant compounds in rice bran by Rhizopus oryzae. Brazil. Arch. Biol. Technol. 2012, 55, 937-942. [CrossRef]

163. Adebo, O.A.; Njobeh, P.B.; Mulaba-Bafubiandi, A.F.; Adebiyi, J.A.; Desobgo, S.C.Z.; Kayitesi, E. Co-influence of fermentation time and temperature on physicochemical properties, bioactive components and microstructure of ting (a Southern African food) from whole grain sorghum. Food Biosci. 2018, 25, 118-127. [CrossRef]

164. Adebo, O.A.; Njobeh, P.B.; Kayitesi, E. Fermentation by Lactobacillus fermentum strains (singly and in combination) enhances the properties of ting from two whole grain sorghum types. J. Cereal Sci. 2018, 82, 49-56. [CrossRef]

165. Adebo, O.A.; Njobeh, P.B.; Mulaba-Bafubiandi, A.F.; Adebiyi, J.A.; Desobgo, Z.S.C.; Kayitesi, E. Optimization of fermentation conditions for ting production using response surface methodology. J. Food Proces. Preserv. 2018, 42, e13381. [CrossRef]

166. Elkhalifa, A.E.O.; Schiffler, B.; Bernhard, R. Effect of fermentation on the starch digestibility, resistant starch and some physicochemical properties of sorghum flour. Food/Nahrung 2004, 48, 91-94. [CrossRef] [PubMed]

167. Jood, S.; Khetarpaul, N.; Goyal, R. Effect of germination and probiotic fermentation on pH, titratable acidity, dietary fibre, $\beta$-glucan and vitamin content of sorghum-based food mixtures. J. Nutr. Food Sci. 2012, 2, 1-4. [CrossRef]

168. Ojha, P.; Adhikari, R.; Karki, R.; Mishra, A.; Subedi, U.; Karki, T.B. Malting and fermentation effects on antinutritional components and functional characteristics of sorghum flour. Food Sci. Nutr. 2018, 6, 47-53. [CrossRef]

169. Ojokoh, A.O.; Eromosele, O. Effect of fermentation on proximate composition and microbiological changes of sorghum and pumpkin blend. Br. Microbiol. Res. J. 2015, 10, 1-4. [CrossRef]

170. Wedad, H.A.; El Tinay, A.H.; Mustafa, A.I.; Babiker, E.E. Effect of fermentation, malt-pretreatment and cooking on antinutritional factors and protein digestibility of sorghum cultivars. Pak. J. Nutr. 2008, 7, 335-341. [CrossRef]

171. Zhang, Z.; Lei, Z.; Yun, L.; Zhongzhi, L.; Chen, Y. Chemical composition and bioactivity changes in stale rice after fermentation with Cordyceps sinensis. J. Biosci. Bioeng. 2008, 106, 188-193. [CrossRef]

172. Tamene, A.; Kariluoto, S.; Baye, K.; Humblot, C. Quantification of folate in the main steps of traditional processing of tef injera, a cereal based fermented staple food. J. Cereal Sci. 2019, 87, 225-230. [CrossRef]

173. Onwuliri, V.A.; Attah, I.; Nwankwo, J.O. Anti-nutritional factors, essential and non-essential fatty acids composition of $U g b a$ (Pentaclethra macrophylla) seeds at different stages of processing and fermentation. J. Biol. Sci. 2004, 4, 671-675.

174. Onoja, U.S.; Obizoba, I.C. Nutrient composition and organoleptic attributes of gruel based on fermented cereal, legume, tuber and root flour. Agro-Sci. J. Trop. Agric. Food Environ. Ext. 2009, 8, 162-168. [CrossRef]

175. Ijarotimi, O.S.; Esho, T.R. Comparison of nutritional composition and anti-nutrient status of fermented, germinated and roasted bambara groundnut seeds (Vigna subterranea). Br. Food J. 2009, 111, 376-386. [CrossRef]

176. Ola, O.I.; Opaleye, S.O. Effect of fermentation on antinutritional factors and functional properties of fermented Bambara nut flour. Asian Food Sci. J. 2019, 11, 1-5. [CrossRef]

177. Chawla, P.; Bhandari, L.; Sadh, P.K.; Kaushik, R. Impact of solid-state fermentation (Aspergillus oryzae) on functional properties and mineral bioavailability of black-eyed pea (Vigna unguiculata) seed flour. Cereal Chem. 2017, 94, 437-442. [CrossRef]

178. Reyes-Moreno, C.; Cuevas-Rodríguez, E.O.; Milan-Carrillo, J.; Cardenas-Valenzuela, O.G.; Barron-Hoyos, J. Solid state fermentation process for producing chickpea (Cicer arietinum L.) tempeh flour. Physicochemical and nutritional characteristics of the product. J. Sci. Food Agric. 2004, 84, 271-278. [CrossRef]

179. Doblado, R.; Frias, J.; Muñoz, R.; Vidal-Valverde, C. Fermentation of Vigna sinensis var. carilla flours by natural microflora and Lactobacillus species. J. Food Prot. 2003, 66, 2313-2320. [CrossRef] [PubMed]

180. Granito, M.; Torres, A.; Frías, J.; Guerra, M.; Vidal-Valverde, C. Influence of fermentation on the nutritional value of two varieties of Vigna sinensis. Eur. Food Res. Technol. 2005, 220, 176-181. [CrossRef]

181. Prinyawiwatkul, W.; Beuchat, L.R.; McWatters, K.H.; Phillips, R.D. Fermented cowpea flour: Production and characterization of selected physico-chemical properties. J. Food Proces. Preserv. 1996, 20, 265-284. [CrossRef]

182. Ayuk, A.A.; Iyayi, E.A.; Okon, B.I.; Ayuk, J.O.; Jang, E. Biodegradation of antinutritional factors in whole leaves of Enterolobium cyclocarpum by Aspergillus niger using solid state fermentation. J. Agric. Sci. 2018, 6, 188-196. [CrossRef]

183. Ojha, P.; Bhurtel, Y.; Karki, R.; Subedi, U. Processing effects on anti-nutritional factors, phytochemicals, and functional properties of horse gram (Macrotyloma uniflorum) flour. J. Microbiol. Biotechnol. Food Sci. 2020, 9, 1080-1086. [CrossRef]

184. Granito, M.; Frias, J.; Doblado, R.; Guerra, M.; Champ, M.; Vidal-Valverde, C. Nutritional improvement of beans (Phaseolus vulgaris) by natural fermentation. Eur. Food Res. Technol. 2002, 214, 226-231. [CrossRef]

185. Dhull, S.B.; Punia, S.; Kidwai, M.S.; Kaur, M.; Chawla, P.; Purewal, S.S.; Sangwan, M.; Palthania, S. Solid-state fermentation of lentil (Lens culinaris L.) with Aspergillus awamori: Effect on phenolic compounds, mineral content, and their bioavailability. Legume Sci. 2020, 2, e37. [CrossRef]

186. Farinde, E.O.; Olanipekun, O.T.; Olasupo, R.B. Nutritional composition and antinutrients content of raw and processed lima bean (Phaseolus lunatus). Ann. Food Sci. Technol. 2018, 19, 250-264.

187. Bartkiene, E.; Krungleviciute, V.; Juodeikiene, G.; Vidmantiene, D.; Maknickiene, Z. Solid state fermentation with lactic acid bacteria to improve the nutritional quality of lupin and soya bean. J. Sci. Food Agric. 2015, 85, 1336-1342. [CrossRef] [PubMed]

188. Frias, J.; Miranda, M.L.; Doblado, R.; Vidal-Valverde, C. Effect of germination and fermentation on the antioxidant vitamin content and antioxidant capacity of Lupinus albus L. var. Multolupa. Food Chem. 2005, 92, 211-220. [CrossRef] 
189. Starkute, V.; Bartkiene, E.; Bartkevics, V.; Rusko, J.; Zadeike, D.; Juodeikiene, G. Amino acids profile and antioxidant activity of different Lupinus angustifolius seeds after solid state and submerged fermentations. J. Food Sci. Technol. 2016, 53, 4141-4148. [CrossRef]

190. Olaleye, H.T.; Oresanya, T.O.; Ogundipe, O.O. Comparative study on proximate and antinutritional factors of dehulled and undehulled fermented Lyon bean (Mucuna cochinchinensis). Food Res. 2020, 4, 1611-1615. [CrossRef]

191. Igbabul, B.; Hiikyaa, O.; Amove, J. Effect of fermentation on the proximate composition and functional properties of mahogany bean (Afzelia africana) flour. Curr. Res. Nutr. Food Sci. J. 2014, 2, 1-7. [CrossRef]

192. Onwurafor, E.U.; Onweluzo, J.C.; Ezeoke, A.M. Effect of fermentation methods on chemical and microbial properties of mung bean (Vigna radiata) flour. Niger. Food J. 2014, 32, 89-96. [CrossRef]

193. Odion-Owase, E.; Ojokoh, A.O.; Oyetayo, V.O. Effect of different fermentation methods on the microbial and proximate composition of pigeon pea (Cajanus cajan). Microbiol. Res. J. Int. 2018, 23, 1-6. [CrossRef]

194. Amadou, I.; Amza, T.; Foh, M.B.K.; Kamara, M.T.; Le, G.W. Influence of Lactobacillus plantarum Lp6 fermentation on the functional properties of soybean protein meal. Emir. J. Food Agric. 2010, 22, 456-465. [CrossRef]

195. Lai, L.R.; Hsieh, S.C.; Huang, H.Y.; Chou, C.C. Effect of lactic fermentation on the total phenolic, saponin and phytic acid contents as well as anti-colon cancer cell proliferation activity of soymilk. J. Biosci. Bioeng. 2013, 115, 552-556. [CrossRef] [PubMed]

196. Rashad, M.M.; Mahmoud, A.E.; Abdou, H.M.; Nooman, M.U. Improvement of nutritional quality and antioxidant activities of yeast fermented soybean curd residue. Afr. J. Biotechnol. 2011, 10, 5504-5513.

197. Olagunju, O.F.; Ezekiel, O.O.; Ogunshe, A.O.; Oyeyinka, S.A.; Ijabadeniyi, O.A. Effects of fermentation on proximate composition, mineral profile and antinutrients of tamarind (Tamarindus indica L.) seed in the production of daddawa-type condiment. LWT-Food Sci. Technol. 2018, 90, 455-459. [CrossRef]

198. Oluseyi, E.O.; Temitayo, O.M. Chemical and functional properties of fermented, roasted and germinated tamarind (Tamarindus indica) seed flours. Nutr. Food Sci. 2015, 45, 97-111. [CrossRef]

199. Difo, H.V.; Onyike, E.; Ameh, D.A.; Njoku, G.C.; Ndidi, U.S. Changes in nutrient and antinutrient composition of Vigna racemosa flour in open and controlled fermentation. J. Food Sci. Technol. 2015, 52, 6043-6048. [CrossRef]

200. Nyako, K.O.; Danso, K.O. Role of added yeast in the acceptability of naturally fermented corn dough. In Proceedings of a Regional Workshop on Traditional African Foods—Quality and Nutrition, Dares Salaam, Tanzania, 3-5 November 1992; Westby, A., Reilly, P.J.A., Eds.; International Foundation for Science: Stockholm, Sweden, 1991; pp. 19-21.

201. Petrova, P.; Petrov, K. Lactic acid fermentation of cereals and pseudocereals: Ancient nutritional biotechnologies with modern applications. Nutrients 2020, 12, 1118. [CrossRef]

202. Coutron-Gambotti, C.; Gandemer, G. Lipolysis and oxidation in subcutaneous adipose tissue during dry-cured ham processing. Food Chem. 1999, 64, 95-101. [CrossRef]

203. Liquori, A.; Belsito, E.L.; Di Gioia, M.L.; Leggio, A.; Malagrino, F.; Romio, E.; Siciliano, C.; Tagarelli, A. GC/MS analysis of fatty acids in Italian dry fermented sausages. Open Food Sci. J. 2015, 9, 5-13. [CrossRef]

204. Chen, Q.; Kong, B.; Han, Q.; Xia, X.; Xu, L. The role of bacterial fermentation in lipolysis and lipid oxidation in Harbin dry sausages and its flavour development. LWT-Food Sci Technol. 2017, 77, 389-396. [CrossRef]

205. García, C.; Rendueles, M.; Díaz, M. Liquid-phase food fermentations with microbial consortia involving lactic acid bacteria: A review. Food Res. Int. 2019, 119, 207-220. [CrossRef]

206. Adebiyi, J.A.; Kayitesi, E.; Adebo, O.A.; Changwa, R.; Njobeh, P.B. Food fermentation and mycotoxin detoxification: An African perspective. Food Control 2019, 106, 106731. [CrossRef]

207. Omojokun, A.O.; Jokoh, A.O. Effects of fermentation and extrusion on the mineral and antinutrient composition of plantaincowpea flour blends. Asian J. Emerg. Res. 2020, 2, 190-199.

208. Hawashi, M.; Altway, A.; Widjaja, T.; Gunawan, S. Optimization of process conditions for tannin content reduction in cassava leaves during solid state fermentation using Saccharomyces cerevisiae. Heliyon 2019, 5, e02298. [CrossRef] [PubMed]

209. Udensi, E.A.; Ekwu, F.C.; Isinguzo, J.N. Antinutrient factors of vegetable cowpea (Sesquipedalis) seeds during thermal processing. Pak. J. Nutr. 2007, 6, 194-197.

210. Cossa, J.; Oloffs, K.; Kluge, H.; Drauschke, W.; Jeroch, H. Variabilities of total and phytate phosphorus contents as well as phytase activity in wheat. J. Agric. Trop. Subtrop. 2000, 101, 119-126.

211. Reale, A.; Konietzny, U.; Coppola, R.; Sorrentino, E.; Greiner, R. The importance of lactic acid bacteria for phytate degradation during cereal dough fermentation. J. Agric. Food Chem. 2007, 55, 2993-2997. [CrossRef]

212. Licandro, H.; Ho, P.H.; Nguyen, T.K.C.; Petchkongkaew, A.; Van Nguyen, H.; Chu-Ky, S.; Nguyen, T.V.A.; Lorn, D.; Waché, Y. How fermentation by lactic acid bacteria can address safety issues in legumes food products? Food Control 2020, $110,106957$. [CrossRef]

213. Hassan, G.F.; Yusuf, L.; Adebolu, T.T.; Onifade, A.K. Effect of fermentation on mineral and anti-nutritional composition of cocoyam (Colocasia esculenta linn). Sky J. Food Sci. 2015, 4, 42-49.

214. Joye, I. Protein digestibility of cereal products. Foods 2019, 8, 199. [CrossRef]

215. Annor, G.A.; Tyl, C.; Marcone, M.; Ragaee, S.; Marti, A. Why do millets have slower starch and protein digestibility than other cereals? Trends Food Sci. Technol. 2017, 66, 73-83. [CrossRef]

216. Wu, T.; Taylor, C.; Nebl, T.; Ng, K.; Bennett, L.E. Effects of chemical composition and baking on in vitro digestibility of proteins in breads made from selected gluten-containing and gluten-free flours. Food Chem. 2017, 233, 514-524. [CrossRef] [PubMed] 